UNIVERSIDADE DE SÃO PAULO

FACULDADE DE FILOSOFIA, LETRAS E CIÊNCIAS HUMANAS

SAMARA FERNANDA ALMEIDA OLIVEIRA DE LÓCIO E SILVA GESKE

\title{
O Avesso e o Direito da escritura camusiana: de L'Étranger aos Écrits de Jeunesse.
}

v. 1 
SAMARA FERNANDA ALMEIDA OLIVEIRA DE LÓCIO E SILVA GESKE

\title{
O Avesso e o Direito da escritura camusiana: de L'Étranger aos Écrits de Jeunesse.
}

\begin{abstract}
v. 1
Dissertação apresentada ao Programa de Pós-Graduação em Estudos Línguisticos, Literários e Tradutológicos em Francês do Departamento de Letras Modernas da Faculdade de Filosofia, Letras e Ciências Humanas da Universidade de São Paulo, para a obtenção do título de Mestre em Letras.

Orientador (a): Profa. Dra. Claudia Amigo Pino
\end{abstract}

São Paulo 
Samara Fernanda Almeida Oliveira de Lócio e Silva Geske

O Avesso e o Direito da escritura camusiana: de L'Étranger aos Écrits de Jeunesse

Dissertação apresentada ao Programa de Pós-Graduação em Estudos Línguisticos, Literários e Tradutológicos em Francês do Departamento de Letras Modernas da Faculdade de Filosofia, Letras e Ciências Humanas da Universidade de São Paulo, para a obtenção do título de Mestre em Letras.

Orientador (a): Profa. Dra. Claudia Amigo Pino

Aprovado (a) em:

Banca examinadora

Prof. Dr.

Instituição

Julgamento Assinatura

Prof. Dr. Instituição

Julgamento Assinatura

Prof. Dr. Instituição

Julgamento Assinatura 
Para meu pai, "Le Premier Homme". 


\section{AGRADECIMENTOS}

À CAPES, pela bolsa que permitiu a dedicação exclusiva a esta pesquisa.

À Claudia Amigo Pino, pela orientação generosa de todos esses anos e por transmitir a mim o amor pela crítica.

A Franklin Leopoldo e Silva e Nilson Adauto G. da Silva, por tão gentilmente aceitarem a tarefa de ler e discutir este trabalho.

Ao Grupo Criação e Crítica, parceiros nas discussões, leituras e crescimento acadêmico.

A todas as amigas que tornaram essa caminhada pelo universo da literatura francesa muito mais bonita, em especial a Regina K. S. Mergulhão, Luciana Antonini Schoeps e Lúcia Amaral Ribeiro.

À Millyane Moura, amiga e irmã, pela revisão cuidadosa do texto.

À Cicilia Geske, por proporcionar a tranquilidade e o conforto no qual muitas destas páginas foram escritas.

A Marcel e à Brenda de Lócio e Silva, porque eu nunca me senti sozinha.

À Rita de Lócio e Silva, por seu apoio incondicional nestes anos de universidade e por seu amor incondicional que me acompanha na vida.

A André Luiz Geske, pela união que começou em meio a esse mestrado, pela felicidade que eu espero que dure até o fim da vida. 
“O Lumière! C'est le cri de tous les personnages placés, dans le drame antique, devant leur destin. Ce recours dernier était aussi le nôtre et je le savais maintenant. Au milieu de l'hiver, j’apprenais enfin qu'il y avait en moi un été invincible." 


\section{RESUMO}

GESKE, Samara Fernanda Almeida Oliveira de Lócio e Silva. O avesso e o direito da escritura camusiana: de L'Étranger aos Écrits de Jeunesse. 2011. 130 páginas. Dissertação (Mestrado) FFLCH, USP. SP. 2011.

L'Étranger e Le Mythe de Sisyphe fazem parte do que Camus nomeou de ciclo do absurdo,no qual se unem sob esse mesmo tema a escrita literária e a reflexão filosófica. O absurdo é essencialmente definido como um divórcio do homem com o mundo, mas encontramos no percurso filosófico do autor uma noção anterior a essa, as núpcias. A análise de todos os textos anteriores ao ciclo do absurdo nos mostra, porém, que núpcias e absurdo sempre fizeram parte da reflexão camusiana. Essas duas noções opostas sempre conviveram juntas, formando o que chamamos de o avesso e o direito, ideia que se reflete no título da primeira recolha de ensaios do autor. O objetivo dessa dissertação é, através de todos os escritos anteriores à narrativa, definir o avesso e o direito como um tema fundamental para a escritura de L'Étranger, onde se conjugam as núpcias e o absurdo, a literatura e a filosofia.

Palavras-chave: Albert Camus; L'Étranger; absurdo; núpcias; o avesso e o direito; literatura; filosofia. 


\section{ABSTRACT}

GESKE, Samara Fernanda Almeida Oliveira de Lócio e Silva - The Wrong Side and The Right Side of camusian scripture: From L'Étranger to Écrits de Jeunesse. 2011. 130 pages. Dissertation (Masters Degree) FFLCH, USP. SP.2011.

L'Étranger and Le Myth de Sisyphe make part of what Camus named as the absurd cycle, where the literary writing and the philosophical reflection are joined together under the same theme. The absurd is essentially definite as a divorce of man with the world, but we meet in the author's philosophical course a previous notion to it, the nuptials. The analysis of all former texts to the absurd cycle, show us, nevertheless, that nuptials and absurd always were part of camusian reflection. These two opposite notions always lived together, shaping what we call the wrong side and the right side, the title of the author's first reunion of essays. The purpose of this dissertation is, through the all writings written before the narrative, definite the wrong side and the right side

as a fundamental theme to the scripture of L'Etranger, where the nuptials and the absurd, the literature and philosophy are joined together.

Keywords: Albert Camus; L'Étranger; absurd; nuptials; the wrong side and the right side; literature; philosophy. 


\section{RÉSUMÉ}

GESKE, Samara Fernanda Almeida Oliveira de Lócio e Silva - L'Envers et L'Endroit de l'écriture camusienne: de L'Étranger aux Écrits de Jeunesse. 2011. 130 pages. Dissertation (Master) FFLCH, USP. SP.2011.

L'Étranger et Le Mythe de Sisyphe font partie du cycle de l'absurde, dans lequel s'unifient sous ce thème l'écriture littéraire et la réflexion philosophique. L'absurde est essentiellement défit comme un divorce de l'homme et le monde, pourtant on trouve dans le parcours philosophique de l'auteur un concept antérieur à celui-ci, les noces. L'analyse de tous les textes antérieurs au cycle de l'absurde, nous montrent cependant que noces et absurde ont fait partie de la réflexion camusienne. Ces deux concepts opposés ont toujours vécu ensemble et forment ce que nous appelons l'envers et l'endroit, idée réflechie dans le titre de la première réunion d'essais de l'auteur. L'objectif de cette dissertation c'est, à travers tous les écrits antérieurs au récit, définir l'envers et l'endroit comme le thème fondamental pour l'écriture de L'Étranger, dans lequel se conjuguent les noces et l'absurde, la littérature et la philosophie.

Mot-clés: Albert Camus; L'Étranger; absurde; noces; l'envers et l'endroit; littérature; philosophie 


\section{LISTA DE ABREVIAÇÕES}

As obras de Albert Camus utilizadas para a elaboração deste texto, tal qual indicadas na bibliografia, serão citadas obedecendo às indicações abaixo, seguidas das respectivas páginas:

Carnets I (C I)

Carnets II (C II)

Carnets III (C III)

Dictionnaire Albert Camus (Dic.)

Essais (E)

L'Envers et L'Endroit (EE)

Écrits de Jeunesse (EJ)

L'Étranger (Et)

L'Homme Révolté (HR)

A inteligência e o cadafalso (IC)

A morte feliz (MF)

Le Mythe de Sysiphe (MS)

Noces $(\mathrm{N})$

Oeuvres Complètes I (OC I)

Théâtre, Récit et Nouvelles (TRN)

Política das citações:

1. Para as citações no corpo do texto foram utilizadas a edição em português das obras de Camus, bem como a tradução livre, no caso dos textos ainda não traduzidos.

2. Para as citações com mais de três linhas foram utilizadas as edições originais dos textos, com tradução nas notas de rodapé.

3. Todas as referências no corpo do texto são das edições francesas. 


\section{SUMÁRIO}

INTRODUÇÃO 13

Os (des)caminhos da pesquisa __ 13

Em torno do ciclo do absurdo__ 16

O drama do absurdo — 18

As Núpcias e o Absurdo _ 21

O AVESSO E O DIREITO DA ESCRITURA ________________________ 25

Apresentação _— 25

1. A sedução do avesso e o direito — 27

1.1 A circulação de um tema___ 31

2. Uma unidade que se ignorava __ 34

3. Literatura e Filosofia: o avesso e o direito da escritura __ 42

3.1 A evidência e o lirismo: os ensaios___ 42

3.2 Pensamento e imagens: o romance___ 46

3.3 Onde um começa e o outro termina? __ 49

A MORTE PARA TODOS, PARA CADA UM A SUA MORTE ___ 53

Apresentação _ـ 53

1. Hoje mamãe morreu...

1.1 Os ritos da morte _ 55

$1.2 \mathrm{Um}$ estranho sentimento __ 62

2. Disparei quatro vezes contra um corpo inerte... 68

3. Peço-vos a cabeça deste homem... — 73

3.1Uma preparação para a morte _ 73

3.2 Uma doença que não se cura___ 75

3.3 A morte certa___ 80

3.4 A alegria da escrita __ 83 
1. Duas partes: inseparáveis e complementares

2. O silêncio e o canto das palavras

3. Meursault: obscuridade e claridade

4. Natureza: beleza e indiferença

4.1 Os banhos de mar: prazer, mulher, comunhão

4.2 O sol: luz e morte

4.2.1 A aliança morte/luz: o enterro

4.2.2 A aliança luz/morte: o assassinato

4.2.3 A aliança morte/luz: a condenação à morte 112

5. A terna indiferença de $L$ 'Étranger 113

CONSIDERAÇÕES FINAIS 116

Tudo isso não se concilia? 116

Aberturas críticas 


\section{INTRODUÇÃO}

\section{Os (des)caminhos da pesquisa}

No ano de 2004, eu era aluna do primeiro ano da habilitação em francês, cursando minha primeira disciplina de literatura francesa. Por um problema de saúde o professor teve de se afastar de suas atividades e a professora Claudia Amigo Pino veio para substituí-lo. À prova final que deveríamos fazer no final do curso, a professora propôs um trabalho para o qual deveríamos escolher um livro dentre uma lista que ela nos apresentou e fazer uma leitura a partir dos textos críticos apresentados em sala de aula.

Eu reconheci nessa lista o título de um livro que eu pensava ter visto na estante em casa, tratava-se de um livro de capa dura vermelha que eu tinha algumas vezes rabiscado quando criança. Era justamente L’Étranger, que meu pai havia comprado ainda no início de sua faculdade.

Lembro-me bem dessa primeira leitura, lembro-me até do lugar onde estava e do sentimento que ela me causou: um enorme mal-estar diante da indiferença de Meursault. Mas em lugar de abandonar o livro seguiu-se em mim o desejo de compreender se esse mal-estar poderia ser um efeito de leitura e como ele se daria. Meu trabalho justamente tematizou o lugar do leitor em L'Étranger e o processo de leitura a partir dos textos "O que é a leitura”, de Jean-Paul Sartre, e "O ato de leitura", de Wolfang Iser.

Surgia ali, sem que eu ainda estivesse consciente disso, a inquietação diante de dois temas centrais: a morte e o sol. Eu observava na narrativa uma espécie de ritmo solar e mortal, que se resumia na estranha explicação de Meursault: "matei por causa do sol”. Justificativa diante da qual, no julgamento, o público e o júri riem. A pergunta que se colocou para mim foi se o leitor, conhecendo a história que fora narrada por Meursault, também riria dessa colocação.

Explico melhor: nos anos que se seguiram, desenvolvi uma pesquisa de Iniciação Científica na qual retomava a questão do processo de leitura do romance. Com base na Estética da Recepção, tentei esmiuçar a repercussão dessas duas imagens no leitor e elaborar uma espécie de discurso em defesa de Meursault: à medida que a imagem do sol se repete na primeira parte da 
narrativa, o leitor vai sendo envolvido por aquele ritmo solar que encontra o seu ápice na cena do assassinato, e ele poderia assim compreender esse ato. O júri, por sua vez, tem acesso apenas à versão "coerente" dos fatos feita pelo procurador e não encontra sentido nesse ato, nem nos outros atos de Meursault, e, por isso, o condena. O júri poderia propor assim um papel a ser seguido pelo leitor, pois ao tentar encarar Meursault como um personagem tradicional, ao tentar dar uma coerência a essa história o leitor também se frustraria.

Essa frustração se daria principalmente por causa de um repertório que faria parte do texto, mas que não era compartilhado pelo leitor: o absurdo apresentado em Le Mythe de Sisyphe. Em uma contradição de termos, o sentido dos atos de Meursault poderia ser encontrado no absurdo, pois o estranhamento causado pelo sol marca exatamente o divórcio entre o homem e o mundo. $\mathrm{O}$ absurdo foi encarado assim como um efeito de leitura, como um divórcio entre o texto e o leitor que está sempre em busca de um sentido. O absurdo não está de forma alguma explicitado no texto, mas ele surgiria exatamente no processo de leitura. Surgira então para mim um novo tema: o absurdo, sob o qual Camus escrevera um ensaio filosófico, uma narrativa e duas peças de teatro.

Ao longo do trabalho de pesquisa, entre as diversas leituras teóricas, encontrei em uma incursão à estante da biblioteca que guarda os livros de Camus um título que chamou minha atenção: La Mort Heureuse. Lendo a introdução desse livro, descobri que se tratava de um romance escrito antes de L'Étranger e que Camus não havia publicado. Essa leitura me decepcionou, uma vez que não encontrei ali o estilo que havia me tocado na primeira leitura. Porém, despertara minha atenção à relação explícita que eu observava entre os dois textos através da repetição de personagens, de aspectos do enredo e de passagens inteiras do texto. Dessa relação entre as duas narrativas surgira uma questão: como esses dois textos podiam estabelecer uma relação clara ao mesmo tempo em que se diferenciavam profundamente. Essa diferença era, sobretudo, no que tange ao estilo do texto. Ao pensar a relação entre L'Étranger e Le Mythe de Sisyphe, percebi que o tema do absurdo parecia estar ausente de La Mort Heureuse, assim a diferença fundamental na passagem de uma narrativa para outra estava nessa relação com o ensaio filosófico: o absurdo não estava apenas no processo de leitura, mas também no processo de criação da narrativa.

Essa pergunta norteou a escrita do projeto de mestrado: em primeiro lugar, meu objetivo era analisar, sob o ponto de vista do processo de criação, a relação entre a narrativa abandonada e 
L'Étranger, a recuperação de alguns temas e imagens e a reescritura de algumas passagens. Em seguida, meu objetivo era analisar a relação entre literatura e filosofia no processo de criação de L'Étranger e como os temas e as imagens de Le Mythe de Sisyphe se transformariam em temas literários.

Aos poucos a primeira relação com La Mort Heureuse foi se esmaecendo e a reflexão sobre o absurdo ganhando espaço. Ao ler os cadernos de anotações de Camus, comecei a perceber que poderia traçar uma espécie de gênese da noção do absurdo: como e quando ela havia aparecido pela primeira vez, como ela havia sido empregada em Le Mythe de Sisyphe e como apareceria em L'Étranger. No romance, essa noção apareceria através de temas e imagens, entre os quais eu havia identificado a morte como principal, uma vez que ela é reiterada três vezes na narrativa.

Meu projeto inicial, intitulado "A Gênese do Absurdo: dos Écrits de Jeunesse à L'Étranger", tinha por objetivo apresentar no primeiro capítulo uma discussão sobre a relação entre filosofia e literatura nos escritos camusianos, bem como a gênese da noção de absurdo. No segundo capítulo pretendia explorar a gênese de algumas imagens e temas relacionados ao absurdo, como a morte, a mãe e a natureza. Finalmente, no terceiro capítulo meu objetivo era mostrar como o absurdo seria fundamental para a estrutura da narrativa.

Ao longo da escrita do trabalho, comecei a perceber alguns elementos que não se adequavam à minha proposta, momentos nos quais eu não observava o absurdo na narrativa, mas algo diverso. Essa questão se colocou como um grande problema: ela exigiria uma dissimulação de minha parte ou então a busca desse algo diverso, o que acarretaria consequentemente um desvio ao projeto inicial. Imbuída pelo prazer da pesquisa escolhi a segunda opção. O que se segue aqui é a tentativa de transmitir ao meu leitor o (des)caminho que me levou não a traçar a gênese do absurdo, mas a encontrar o tema desta dissertação. 


\section{Em torno do ciclo do absurdo}

L'Étranger é publicado em maio de 1942 na França e Le Mythe de Sisyphe: essai sur l'absurde aparece em outubro do mesmo ano. O desejo de Camus era que essas duas obras fossem publicadas simultaneamente, mas isso não foi possível: na França ocupada pelos alemães, conseguir papel para a impressão era muito difícil. Essa publicação concomitante foi primariamente sugerida por André Malraux, que ao ler os dois textos ainda em estado de manuscrito escreve para Camus (outubro de 1941) que a aproximação entre Sisyphe e L'Étranger tinha mais consequências do que ele poderia supor: o ensaio, afirma ele, dá ao livro seu sentido pleno e, sobretudo, transforma o que no romance parecia monocromático e quase pobre (TODD, 2006, p. 384). Camus lhe responde que é exatamente esse o seu procedimento: a ideia de que uma obra pode esclarecer a outra (TODD, 2006, p. 385). Justamente em Le Mythe de Sisyphe, ele aprofunda essa concepção ao escrever que a criação de um homem é única e se consolida a partir da apresentação sucessiva e múltipla que são as suas obras: umas completam as outras, corrigemnas ou as recuperam (MS, 2008, p. 155). Essa "criação única" é nesse caso o absurdo.

Essa relação foi logo percebida pela crítica. Em 1943, ${ }^{1}$ a narrativa recebe uma de suas primeiras críticas, trata-se de "Explication de L'Étranger" de Jean-Paul Sartre, onde ele escreve que: "Mal saído da tipografia, $O$ Estrangeiro de Camus conheceu enorme êxito [...] Em $O$ mito de Sísifo, publicado alguns meses mais tarde, Camus nos deu o comentário exato de sua obra." (SARTRE, 2005, p. 117). Nesse texto, a análise de L'Étranger é sempre pautada por Le Mythe de Sisyphe, pois, para o crítico, o ensaio nos mostraria a maneira de interpretar o romance (2005, p. 121). Enquanto o primeiro nos inspiraria o sentimento do absurdo, o segundo nos ofereceria a sua noção (2005, p. 124).

Se essa relação fica evidente no processo de leitura, o processo de criação desses textos também tem muito a nos dizer: ensaio e narrativa conviveram juntos por alguns anos sobre a mesa de trabalho e na mente do escritor. Podemos seguir esse processo de escrita principalmente através de notações e cartas que Camus escreve relatando o andamento de seu trabalho.

Em fevereiro de 1939, escrevendo à sua futura mulher Cathérine, ele relata que havia começado no dia anterior o seu trabalho: "Como eu tinha te dito (e eu tinha me dito) que

${ }^{1}$ É importante ressaltar que na época em que o artigo foi escrito, setembro de 1942, Le Mythe ainda não havia sido publicado: Sartre o havia lido ainda sob o estado das provas finais da editora Gallimard e ficara impressionado (Cf. TODD, 2006). 
começaria por meu romance, foi o meu ensaio sobre o Absurdo que eu iniciei." ${ }^{2}$ E explica que isso se deu pelo fato de que a ideia do ensaio estava bem mais amadurecida nele do que a do romance. Nesses anos, testemunhos acerca de seu trabalho são múltiplos: ele escreve a Jean Grenier que trabalha em seu ensaio sobre o Absurdo (OC I, 2006, p. 1270) e relata a uma amiga, Christiane Galindo, que começara a escrever o seu romance. (OC I, 2006, p. 1244).

Em maio de 1940, ele escreve nos Carnets que L'Étranger está terminado (C I, 1962, p. 215). Em setembro desse ano, ele termina a primeira parte do ensaio (C I, 1962, p. 216). E em fevereiro de 1941, finalmente termina o Mythe: "Terminado Sísifo. Os três Absurdos ${ }^{3}$ estão acabados. Início da liberdade.”(tradução nossa) ${ }^{4}$

Dessa forma, observamos que não somente ensaio e narrativa foram concebidos praticamente de maneira concomitante e estabeleciam entre si uma relação, mas que formavam um ciclo realmente planejado e projetado por Camus

A palavra "absurdidade" aparece nos Carnets pela primeira vez em 1935 em meio a uma série de palavras que se relacionam entre si na forma de um esquema (C I, 1962, p. 23). Em maio de 1936, ela reaparece agora mais particularizada: "Obra filosófica: a absurdidade. Obra literária: força, amor e morte sob o signo da conquista." 6 Aqui, a ideia de um ciclo começa a se delinear na divisão que Camus faz entre uma obra filosófica e uma obra literária que tratariam do mesmo tema: o absurdo.

Em 1938, a ideia de ciclo é colocada em prática em uma longa nota. Ela inicia-se por uma questão: “Sobre o absurdo?” (C I, 1962, p. 141), o que se segue é uma reflexão sobre a condenação à morte, juntamente com alguns fragmentos de narrativa que tratam de um condenado que aguarda sua execução. Em primeiro lugar, observamos uma reflexão sobre o tema (o aspecto mecânico da pena de morte e a lucidez do condenado) que servirá a Le Mythe e, em

\footnotetext{
¿'Hier j'ai commencé vraiment mon travail. Comme je t'avais dit (et je m'étais dit) que je commencerais par mon roman, c'est mon essai sur l'Absurde que j'ai entamé. D'ailleurs il est beaucoup plus mûr en moi que le roman [...]"(TODD, 2006, p. 282)

${ }^{3}$ L'Étranger, Le Mythe de Sisyphe, Le Malentendu e Caligula, respectivamente, narrativa, ensaio e peças teatrais. Ressaltamos que não discutiremos a relação dos dois primeiros com as peças, pois não é nosso objetivo analisar neste trabalho o teatro camusiano. Para introduzir o assunto recomendamos o artigo "De Caligula aux Justes: de l'absurde à la justice", de André Alter em LÉVI-VALENSI, 1970, pp. 18-28. E o livro Les Envers d'un échec: étude sur le théâtre d'Albert Camus,de Raymond Gay-Croisier, Paris: Minard, 1967.

4 “Terminé Sisyphe. Les trois Absurdes sont achevés. Commencements de la liberté.”(C I, 1962, p.224)

${ }^{5}$ Neste trabalho a palavra absurdidade (qualidade, condição ou estado do que é absurdo) será empregada muitas vezes no lugar do termo absurdo.

${ }^{6}$ Oeuvre philosophique: l'absurdité. Oeuvre littéraire: force amour et mort sous le signe de la conquête. (C I, 1962, p.40)
} 
seguida, a tentativa de dar vida a ele através de uma narrativa (a angústia vivida pelo personagem ao aguardar que venham buscá-lo para ser morto) que servirá a L'Étranger.

A concepção de conjunto foi muito utilizada para descrever as suas obras: quando termina a redação de L'Homme Révolté, ele escreve: "Com esse livro acabam-se os dois primeiros ciclos. 37 anos. E agora, a criação pode ser livre?”. (tradução nossa) ${ }^{7}$ Esses dois ciclos se referem ao que ele chamou de ciclo do absurdo e ciclo da revolta, que se organizam a partir de sua relação com certos mitos: ${ }^{8}$ o ciclo do absurdo que relaciona-se ao mito de Sísifo e compõe das obras já citadas, o ciclo da revolta que relaciona-se com o mito de Prometeu e se compõe de La Peste, L’Homme Révolté e Les Justes. Há ainda um ciclo intermediário composto por La Chute e finalmente o ciclo do amor que se relaciona ao mito de Nêmesis (esse último não foi empreendido devido à morte prematura de Camus). ${ }^{9}$

A escrita por ciclos era uma espécie de tarefa que ele se impunha, visto que todas as vezes que aborda essa questão deixa sempre transparecer seu desejo de escrever livremente, sem restrições de tema ou de forma. Essa tarefa, no entanto, tem relação com uma concepção própria de literatura que ele deseja sustentar: a relação profunda entre a escrita literária e a reflexão filosófica. Nesse momento, faz-se necessário compreender o absurdo no interior do pensamento camusiano.

\section{O drama do absurdo ${ }^{10}$}

O absurdo é o ponto zero da reflexão camusiana e figura como a primeira de suas verdades (MS, 2008, p. 51). Embora ele esteja presente nos escritos anteriores a Le Mythe, é somente com o ensaio que essa noção toma contorno.

\footnotetext{
${ }^{7}$ Avec ce livre s'achèvent les deux premiers cycles. 37 ans. Et maintenant, la création peut-elle être libre ?" (C II, 1965, p.345)

8“I. Le Mythe de Sisyphe (absurde) - II. Le Mythe de Prométée (révolte) - III. Le Mythe de Némésis. " (C II, 1965, p. 328)

9،Avant le troisième étage : nouvelles d'« un héros de notre temps ». Thème du jugement et de l'exil. Le troisième étage, c'est l'amour : le Premier Homme, Don Faust. Le mythe de Némésis. La méthode est la sincérité.” (C III, 1989, p. 187)

${ }^{10}$ Entende-se aqui o conceito de drama estritamente como o conflito de dois termos, sem ligar-se necessariamente ao gênero dramático.
} 
Antes de descobrir o absurdo, o homem vive enredado em seus hábitos, esses gestos que a existência demanda (MS, 2008, p. 20). Isso ocorre porque os homens adquirem o hábito de viver antes de adquirir o hábito de refletir (MS, 2008, p. 23). Um dia, porém, o sentimento de absurdidade pode bater na face de qualquer homem (MS, 2008, p. 26). É nesse momento que os cenários desmoronam: no fim de uma vida mecânica, um "porquê" se eleva e inaugura um movimento da consciência. O que se segue é um retorno inconsciente a essa cadeia de atos ou o despertar definitivo. Se escolhermos a segunda opção, temos duas consequências: passamos a viver conscientes ou nos suicidamos (MS, 2008, p. 29).

O suicídio será o tema central de Le Mythe de Sisyphe, pois o absurdo é um jogo mortal que pode levar tanto à lucidez diante da existência quanto à evasão (MS, 2008, p. 19). Para Camus, o suicídio é o único problema filosófico realmente sério (MS, 2008, p. 17): julgar se a vida vale ou não a pena ser vivida é responder a questão fundamental da filosofia.

Há aqui, porém, uma grande contradição, o homem deseja se matar exatamente por viver sob o horizonte da morte, pois ele compreende que todas as suas ações perdem o sentido diante de sua finitude.

Os homens vivem direcionados para o futuro: eles afirmam "amanhã”, "mais tarde”, "com a idade você vai compreender", mas tudo isso não faz sentido, pois em todos os casos se trata de morrer. Um dia, porém, o homem se situa em relação ao tempo e compreende que ele é seu pior inimigo: essa revolta na carne é o absurdo (MS, 2008, p. 30). Ele compreende que é inevitavelmente um condenado à morte:

Après l'absurde, tout se trouve ébranlé. Cette idée que "je suis", ma façon d'agir comme si tout a un sens (même si, à l'occasion, je disais que rien n'en a), tout cela se trouve démenti d'une façon vertigineuse par l'absurdité d'une mort possible. (MS, 2008, p. 82) $)^{11}$

O homem percebe que está separado do mundo, na medida em que sua existência finita é confrontada à natureza que permanece, indiferente à dor e ao sofrimento humanos.

Mas o absurdo revela-se não somente na compreensão da finitude humana, mas também nas atitudes dos próprios homens. A mecânica de seus atos revela sua própria desumanidade: esse

\footnotetext{
11“Depois do absurdo, tudo fica abalado. A ideia de que "existo", minha maneira de agir como se tudo tivesse um sentido (mesmo que, eventualmente, eu diga que nada tem), tudo isso acaba sendo desmentido de maneira vertiginosa pelo asurdo de uma morte possível." (MS, 2008, p. 68)
} 
mal-estar diante da existência é também o absurdo. Os homens passam, assim, a ser estranhos uns aos outros, e em seguida a si mesmos: o estranho que por certas vezes vem ao nosso encontro no espelho, o irmão familiar e inquietante que reencontramos ao rever nossas próprias fotos, é também o absurdo (MS, 2008, p. 31).

O absurdo pode ser percebido também na hostilidade da natureza ao percebermos a que ponto uma paisagem pode nos ser estranha, com qual intensidade ela pode nos desprezar: essa densidade e essa estranheza do mundo é também o absurdo (MS, 2008, p. 31). Isso ocorre porque esses cenários dissimulados pelo hábito voltam a ser o que sempre foram e o homem não se sente mais parte do mundo:

Si j'étais arbre parmi les arbres, chat parmi les animaux, cette vie aurait un sens ou plutôt ce problème n'en aurait point car je ferais partie de ce monde. Je serais ce monde auquel je m'oppose maintenant par toute ma conscience et par toute mon exigence de familiarité. (MS, 2008, p. 76) ${ }^{12}$

É assim que natureza e homem passam a ser personagens de um drama, o drama do absurdo: ele passa a ser seu único laço. ${ }^{13}$ Dessa confrontação, nasce primeiramente uma oposição entre a opacidade do mundo e a exigência de familiaridade do homem, em seguida, surge uma fratura $^{14}$ e, por último, um divórcio. Essa separação entre o homem e sua vida, o ator e seu cenário, é propriamente o sentimento de absurdidade (MS, 2008, p. 20).

O absurdo apresenta-se assim como um drama, um estado de contradição entre o homem e o mundo. Porém, ele não está em nenhum desses termos, mas nasce de sua presença comum (MS, 2008, p. 50). O absurdo é sempre prisioneiro dessa dualidade: entre o espírito que deseja e o mundo que despreza, entre os apelos humanos e o silêncio do mundo.

Em L'Étranger, Meursault vive plenamente essa absurdidade na medida em que está separado de si mesmo e da sociedade que o exila e o condena. Sua separação da natureza chega a tal ponto que esse divórcio é selado por uma morte. Dessa forma, o drama do absurdo, tal como

\footnotetext{
12،"Se eu fosse árvore entre as árvores, gato entre os animais, a vida teria um sentido ou, antes, o problema não teria sentido porque eu faria parte desse mundo. Eu seria esse mundo ao qual me oponho agora com toda minha consciência e com toda a minha exigência de familiaridade." (MS, 2008, p. 64)

13 "Je disais que le monde est absurde et j'allais trop vite. Ce monde en lui-même n'est pas raisonnable, c'est tout ce qu'on peut dire. Mais ce qui est absurde, c'est la confrontation de cet irrationnel et de ce désir éperdu de clarté dont l'appel résonne au plus profond de l'homme. L'absurde dépend autant de l'homme que du monde. Il est pour le moment leur seul lien. Il les scelle l'un à l'autre comme la haine seule peut river les êtres.” (MS, 2008, p.39)

${ }^{14}$ “"Et qu'est-ce qui fait le fond de ce conflit, de cette fracture entre le monde et mon esprit, sinon la conscience que j'en ai?"' (MS, 2008, p. 76)
} 
descrito em Le Mythe, também está presente em L'Étranger: pensamento e narrativa se unem sob o absurdo.

No entanto, ao lermos a narrativa, percebemos uma ambiguidade: ao mesmo tempo em que essa hostilidade da natureza é descrita, nos é apresentada a felicidade e o prazer que seu personagem encontra nessa relação.

\section{As Núpcias e o Absurdo}

Em L'Étranger, a ambiguidade da natureza se reflete principalmente nas imagens do sol e do mar: eles são ao mesmo tempo um signo de felicidade e de infortúnio.

No primeiro capítulo da narrativa, na descrição do velório da mãe de Meursault, a luminosidade e o calor o incomodam. E no enterro, o sol pesa sobre a sua cabeça e torna a paisagem desumana (Et, 1996, p. 20). Mas é sob esse mesmo sol que Meursault encontra o prazer no seu banho de mar quando reencontra Marie, no segundo capítulo. Em outra praia, porém, o sol e o mar se tornam os personagens centrais de um assassinato: o mar envia um sopro espesso e ardente e o sol desce como uma chuva de fogo e fazem com que o gatilho ceda na mão de Meursault (Et, 1996, p. 62). Essa duplicidade da natureza é descrita pelo próprio Meursault quando, ao sair do tribunal, reconhece a paisagem que o conduzia anteriormente a um sono leve e sem sonhos, mas que agora irá conduzi-lo a sua cela: "Como se os caminhos familiares traçados nas noites de verão pudessem conduzi-lo tanto às prisões, como aos sonos inocentes."15

Como explicar essa ambiguidade? Se compreendermos que o absurdo é essencialmente um divórcio entre o homem e o mundo, logicamente para que haja uma experiência de separação é necessário que primeiramente tenha havido uma experiência de união. Dentro do pensamento camusiano, essa experiência foi nomeada de Núpcias.

Nos ensaios de Noces [Núpcias](1938), o homem camusiano parece ainda não ter experimentado o absurdo ao acreditar que pode estabelecer uma comunhão com a natureza. Análoga a descrição do absurdo, na relação das núpcias também não são o homem nem o mundo

\footnotetext{
${ }^{15}$ (Et, 1979, p. 268) "Comme si les chemins familiers tracés dans les ceils d'été pouvaient mener aussi bien aux prisons qu'aux sommeils innocents.” (Et, 1996, p. 97)
} 
que importam, mas somente o acordo entre eles de onde nasce uma espécie de amor (N, 2008, p. 21).

Como explica Melançon (1976, p. 230), esse acordo com a natureza vai da familiaridade ao parentesco, ${ }^{17}$ depois à fraternidade ${ }^{18}$ e se consagra com as núpcias (N, 2008, p. 50). Não somente as núpcias, mas existe mesmo o desejo de dissolução do homem na natureza (N, 2008, p. 25). Porém, não se trata de celebrar as núpcias com a natureza em geral, mas especificamente com a paisagem argelina, como deixam entrever os títulos de alguns ensaios: "Noces à Tipasa", “Le vent à Djémila", "L’Été à Alger”e "Le Désert”.

Ainda que tenhamos apresentado a ideia de comunhão e divórcio separadamente, elas sempre conviveram juntas nos escritos de Camus: todas as obras que citamos foram elaboradas quase que concomitantemente entre os anos de 1935 e 1940. Ademais, essas duas ideias já estavam presentes no primeiro livro publicado de Camus: L'Envers et L'Endroit, de 1937. Nesses ensaios, o homem é descrito em comunhão com a natureza, ao mesmo tempo em que ela se revela indiferente ao ser humano: o narrador percebe no céu um mistério da onde caem ao mesmo tempo a beleza e a indiferença. Para Camus, esse era um dos aspectos do avesso e do direito do mundo: o problema da união e da separação, no qual o homem se sente ao mesmo tempo familiar e estrangeiro à natureza, em que ela é ao mesmo tempo amiga e hostil.

O avesso e o direito se tornam, por sua vez, uma verdadeira poética que norteará os textos camusianos. Podemos segui-la até mesmo nos títulos que ele escolhe para seus livros: primeiramente L'Envers et L'Endroit, em seguida a divisão entre o direito de Noces e o avesso Le Mythe de Sisyphe: essai sur l'absurde para reencontramos essa ideia binária em L’Étranger. Concluímos que não só o absurdo e a relação com Le Mythe foi importante para L'Étranger, mas que a noção do avesso e do direito (que comporta também o absurdo) foi fundamental para a escritura da narrativa.

Essa noção, porém, é ainda anterior aos ensaios de 1937 e já estava presente nos primeiros textos (nomeados de "Escritos de Juventude") que Camus escreve e que servirão também para a composição de L'Envers et L'Endroit. Entre esses escritos, encontramos um breve texto de 1933 destinado a prefaciar um futuro conjunto de ensaios, no qual podemos ler:

\footnotetext{
${ }^{16}$ "L'homme y gagne une certaine familiarité avec le beau visage du monde" (N, 2008, p. 28)

${ }^{17}$ "Etre pur, c'est retrouver cette patrie de l'âme où devient sensible la parenté du monde" (N, 2008, p. 48)

23، La fraternité secrète qui m'accordait au monde ..." (N, 2008, p. 70)
} 
C'est vrai que les pays méditerranéens sont les seuls où je puisse vivre, que j'aime la vie et la lumière ; mais c'est vrai aussi que le tragique de l'existence obsède l'homme et que le plus profond de lui-même y reste attaché. Entre cet envers et cet endroit du monde et de moi-même, je me refuse à choisir. Si vous voyez un sourire sur les lèvres désespérées d'un homme, comment séparer ceci de cela ? (EJ, 1973, p. 299). ${ }^{19}$

Essa é a primeira vez que a fórmula que dará título aos ensaios aparece. ${ }^{20}$ Aqui, vida e luz estão essencialmente ligadas aos países mediterrâneos e se contrapõem ao trágico da existência: a morte e a sombra. $\mathrm{O}$ avesso e o direito são duas faces de uma mesma realidade do mundo e do homem, onde podem se conjugar ao mesmo tempo alegria e desespero. Essa oscilação entre dois pólos é uma espécie de ritmo binário, insistente e despótico, que rege não somente a vida, mas também as ideias, escreve Camus em “L'art dans la communion” (EJ, 1973, p. 245). O avesso e o direito, regeria assim tanto a reflexão filosófica quanto a própria escritura de Camus, dos Écrits de Jeunesse até L'Étranger.

No mundo e no texto, a questão essencial é que não se pode escolher entre elas ${ }^{21}$, nem tampouco separá-las ${ }^{22}$ o avesso e o direito é uma realidade inextricável.

"O mundo existe e o escritor fala", escreveu Barthes. O mundo, tal como o concebia Camus, sustentava-se a partir do avesso e do direito; essa estrutura binária se reflete por sua vez em seus textos. Ao olhar para o mundo da obra camusiana, essa dissertação também se estrutura a partir desse tema. No primeiro capítulo, nosso objetivo é mostrar como o avesso e o direito surge como um tema que norteia a escritura camusiana e como essa estrutura binária é fundamental para compreendermos a intricação entre filosofia e literatura nos textos de Camus. No segundo capítulo, nosso objetivo é analisar a morte, tema fundamental para o avesso e o direito no que

\footnotetext{
19،É verdade que os países mediterrâneos são os únicos onde eu posso viver e deles eu amo a vida e a luz; mas é verdade também que o trágico da existência obceca o homem e que o mais profundo de si mesmo se liga a ele. Entre esse avesso e esse direito do mundo e de mim mesmo, eu me recuso a escolher. Se você vê um sorriso nos lábios desesperados de um homem, como separar um do outro?" (tradução nossa)

${ }^{20}$ Parece que Camus empresta esse título do pessimismo de Kierkegard: "Où il y a un envers, il y a aussi un endroit." Citado por Paul Vialleneix (EJ, 1973, p.86).

${ }^{21}$ Essa parece ter sido a solução encontrada para um problema colocado em outro texto contemporâneo a esse "L'Art dans la communion" onde o narrador afirma: "Son drame: il faut choisir" (EJ, 1973, p. 246).

${ }^{22}$ Para Armengaud esse título é uma metáfora que permite evitar a dialética, o que significa que ele não resolve a contradição, ele ao contrário a sustenta (1997, p. 50).
} 
tange ao percurso filosófico do escritor e, ao mesmo tempo, como esse tema se desdobra literariamente em L'Étranger. O terceiro capítulo se propõe a analisar alguns aspectos da composição da narrativa, como sua divisão em duas partes, sua linguagem e seu personagem, a partir do tema do avesso e do direito. 


\section{O AVESSO E O DIREITO DA}

\section{ESCRITURA}

\section{Apresentação}

Louis Aragon (1979, p. 8), no discurso de entrega de seus manuscritos ao CNRS, afirmou que o campo das relações entre o escritor e o pesquisador é o do escrito: não somente o escrito fixado pela publicação, mas o texto em devir, apreendido durante o tempo da escritura. Como ressalta Hay (2007, p. 17), seu gesto tornou-se um símbolo de uma nova aliança entre criadores e pesquisadores, e assegurou o nascimento "De uma grande nova arte: a pesquisa.". Essa pesquisa tornou-se o campo da crítica genética, que trouxe muitas contribuições para a crítica literária ao criar novas relações a partir de um material a que o crítico não tinha acesso anteriormente. Mais do que o texto publicado, o crítico pode se concentrar sobre a escritura a partir dos manuscritos, das notas de trabalho, dos textos não publicados.

O objetivo deste capítulo é analisar a escritura camusiana, tendo como ponto de partida L'Étranger e retornando aos seus Écrits de Jeunesse, entendendo a escritura não somente como um traço sobre o papel, com suas rasuras, seus acréscimos, etc., mas seguindo-a também como o traço de uma ideia, de um pensamento, de um processo. Esse é um desejo de seguir o que Barthes chamou de "a mitologia pessoal e secreta do autor", em que se instalam os "grandes temas verbais de sua existência": a sua obstinação.

Esse grande tema, o nomeamos aqui de "o avesso e o direito": ele percorre toda a obra de Camus como um fio invisível ligando seus textos: de seus escritos de juventude até L'Étranger, de L'Étranger até Le Premier Homme. Esse curioso fio liga profundamente até mesmo textos que à primeira vista não se misturam e nos ensina que reflexão filosófica e escrita literária são duas faces da mesma moeda. Ao seguir essa ideia na escritura camusiana, principalmente no processo de criação de L'Étranger, nosso objetivo não é mostrar que ela nasceu de repente, por meio de 
"clarões de inspiração", mas que ela é fruto de "uma felicidade cotidiana"23 que ele estabelece com seus textos e que se inicia pelo menos dez anos antes.

23 "Em todo caso, é assim que explico o forte sentimento que encontro na leitura de nossos grandes romances. Eles testemunham a eficácia da criação humana. Com eles, persuadimo-nos de que a obra de arte é uma coisa humana, sempre muito humana, e que o criador pode prescindir de exercícios de transcendência. Eles não nascem de clarões de inspiração, mas de uma felicidade cotidiana." (IC, 2002, p. 24) 


\section{A sedução do avesso e o direito}

A partir da reflexão que fizemos sobre o avesso e o direito, podemos nos perguntar: se L'Envers et L'Endroit é o primeiro livro publicado de Camus, se nele se conjugam núpcias e divórcio, por que ele quase nunca é citado por Camus e ele tampouco o inclui em um ciclo de obras?

A escolha de L'Étranger como nosso ponto de partida não é gratuita: durante muito tempo, nas classificações que faz de sua obra, Camus começa sempre pelo ciclo do absurdo: L'Étranger e Le Mythe representam o ponto zero da sua criação (C II, 1965, p. 31). O crítico Grenier explica que L'Étranger marcou Camus de tal forma que só a partir desse livro ele aceita assumir a sua obra (1987, p. 55).

Mas a escritura de Camus começa pelo menos dez anos antes. Qual seria então o papel de todos esses escritos anteriores?

Em primeiro lugar, podemos conjecturar que Camus nunca cite alguns desses textos escritos entre os anos de 1933 e 1937 e que ele utiliza para escrever os ensaios de L'Envers et L'Endroit - porque muitos deles figuravam apenas como manuscritos. E mesmo L'Envers et L'Endroit, que fora publicado na Argélia, permanecera desconhecido do grande público por muito tempo. Somente em 1958, Camus decide publicar uma reedição da obra, que recebe um longo prefácio no qual reflete principalmente sobre sua escritura. Ele explica que recusara a reimpressão de L'Envers et L'Endroit por causa de sua forma, que sempre lhe parecera ruim; com vinte e dois anos se escreve ainda com dificuldade. Porém, ele não renegava nada do que exprimira nessas páginas carregadas de um "verdadeiro amor” (EE, 2007, p. 13).

A opinião de Camus nos reporta a nossa segunda hipótese, posição também sustentada por Lévi-Valensi, um das principais críticas de Camus. Para a pesquisadora, esses textos são um canteiro de aprendizado e experimentação tanto da forma quanto de temas e imagens, eles fazem parte do que ela chamou de "o nascimento de um escritor":

[...]os textos que precedem L'Étranger são tanto ensaios que se enriquecem progressivamente de suas conquistas e mesmo de seus fracassos; inversamente, é 
evidente que a partir de L'Étranger a obra acede à autonomia de obra-prima e o romance camusiano existe em sua plenitude. ${ }^{24}$

Essa conjectura poderia ser confirmada no próprio prefácio por Camus. Ele identifica L'Envers et L'Endroit como a fonte de tudo o que escrevera posteriormente: "Cada artista mantém, assim no fundo de si mesmo, uma fonte única que alimenta durante a sua vida o que ele é e o que diz. [...] Para mim, sei que minha fonte está em $O$ Avesso e o Direito."25

Ainda que esse livro não possa ser considerado como a origem ou a matriz de todos os outros, pois sabemos todos os entraves dessa ideia, ele pelo menos propõe algumas estruturas e alguns temas que Camus não deixará de explorar em sua escrita. Grenier foi o primeiro crítico a notar essa relação; em um texto de 1943 sobre L'Étranger, ele escreve que: "Esse jovem escritor havia publicado L'Envers et L'Endroit e Noces, onde se desenha em pontilhado a curva que ele traça aqui com uma mão firme.". ${ }^{26}$

No que diz respeito à estrutura, o livro propõe a forma do ensaio, um gênero limítrofe entre literatura e filosofia, que já anuncia a relação entre L'Étranger e Le Mythe de Sysiphe. Em relação ao tema, os textos se compõem a partir do tema geral do avesso e o direito, que por sua vez se dividem em subtemas.

Para Jean Starobinski, um dos maiores nomes da crítica temática, a palavra "tema" tenta definir objetivamente essa sedução exercida pela obra. Que é essa sedução? É aquilo que nos encanta na obra, que nos atrai, que desperta nossa atenção. Essa sedução se faz principalmente através da repetição:

Esses signos me seduziram, eles são portadores do sentido que se realizou em mim: longe de recusar essa sedução, longe de esquecer a revelação primeira do sentido, eu tento compreendê-los, "tematizá-los" no meu pensamento e eu só posso fazê-lo com certa chance de sucesso se ligar estreitamente o sentido ao substrato verbal, a sedução à sua base formal. ${ }^{27}$

\footnotetext{
${ }^{24}[\ldots]$ lestextes qui précèdent L'Étranger sont autant d'essais qui s'enrichissent progressivement de leurs acquis et même de leurs échecs; en revanche, il est évident qu'à partir de L'Étranger, l'œuvre accède à l'autonomie du chefd'œuvre, et le roman camusien existe dans sa plénitude. (2006, p.13)

${ }^{25}$ (EE, 19-?, p. 10) "Chaque artiste garde ainsi, au fond de lui, une source unique qui alimente sa vie ce qu'il est et ce qu'il dit. /.../ Pour moi, je sais que ma source est dans L'Envers et L'Endroit." (EE, 2007, p. 13)

${ }^{26}$ “Ce jeune écrivain avait publié L'envers et L'endroit et Noces où se dessine en pointillé la courbe qu'il trace ici d'une main ferme." (1970, p.36)

${ }^{27}$ “Ses signes m'ont séduit, ils sont porteurs du sens qui s'est réalisé en moi: loin de récuser la séduction, loin d'oublier la révélation première du sens, je cherche à les comprendre à les "thématiser" pour ma propre pensée, et je ne puis le faire avec quelque chance de réussite qu'à la condition de lier étroitement le sens à son substrat verbal, la séduction à sa base formelle.”(1983, p. 17)
} 
A função do crítico é, assim, tematizar essa sedução subjetiva: ele deixa de ser um leitor dócil, seu trajeto não é mais regido pelo da obra, mas ele se distancia para seguir seu próprio percurso. Para Starobinski, a crítica guarda sempre a lembrança dessa doçura, desse encantamento primitivo da obra, mas ela se volta para as estruturas objetivas que determinaram a leitura. Esses signos objetivos se apresentam a partir da composição, do estilo, das imagens e dos valores semânticos, revelando uma interdependência dos efeitos e das estruturas.

Propomos, assim, que existe uma relação temática entre L'Envers et L'Endroit (e todos os textos anteriores a ele) e L'Étranger, pois observamos esses temas que se repetem de um texto para outro formando a sedução do avesso e do direito na escritura camusiana.

O tema do avesso e direito pode ser observado primeiramente a partir dos títulos dos ensaios, nos quais já se alternam luz e sombra, amor e desespero, vida e morte. Esse tema geral se subdivide, por sua vez, em muitos outros, que se ligam tanto à ideia de Núpcias quanto à ideia de Absurdo. Entre eles podemos citar o tema da morte, encontrado no primeiro ensaio, "L'ironie": trata-se da história de uma velha doente e solitária, de um velho que não era mais escutado e da morte de uma avó. Esse ensaio é praticamente a recuperação de dois textos de juventude de Camus: "Le Courage", de 1933, e "Les voix du quartier pauvre", de 1934. Essas histórias aparentemente não parecem ter nada em comum, e o narrador pergunta: "Tudo isso não se concilia?". A resposta aparece numa breve síntese dessas três histórias: uma mulher que se abandona para ir ao cinema, um velho que não é mais escutado, uma morte que não se resgata e, do outro lado, toda a luz do mundo.(EE, 2007, p. 52). Podemos concluir que morte e luz representam o "avesso" e o "direito" do mundo: de um lado a doença, a velhice, a solidão, o desespero; do outro lado toda a indiferente beleza do mundo.

Todos esses temas serão encontrados em L'Étranger: a velhice, principalmente ligada à doença e à solidão, a morte e o enterro da mãe e finalmente a solidão do próprio Meursault na prisão e sua morte. Do outro lado, toda a beleza indiferente da natureza mediterrânea. ${ }^{28}$

"Entre oui et non" tratará principalmente da relação com a mãe: seu silêncio e sua indiferença são como signos do absurdo. Tematicamente, o tema da relação da mãe e do filho será explorado em L'Étranger. E como ressalta Starobinski, os temas se estendem até a estrutura

\footnotetext{
${ }^{28}$ Reservamo-nos a fazer aqui somente alguns apontamentos, essa relação temática entre os ensaios e a narrativa será explorada mais profundamente no segundo capítulo.
} 
da obra, donde podemos afirmar que silêncio e indiferença serviram para a composição do personagem e também podem ser encontrados na própria linguagem e no estilo do texto.

O terceiro ensaio, "La Mort dans l'âme", faz referência a duas viagens que Camus empreende à antiga Tchecoslováquia e à Itália no verão de 1936. O narrador do ensaio descreve o "avesso" e o "direito" dessa experiência de viagem. O texto é dividido em duas partes que se diferenciam quanto ao lugar, ao tempo e ao estado do narrador, que, segundo Lévi-Valensi (2006, p. 396), passa de um sentimento de angústia a uma abertura para a alegria. Na primeira parte o narrador descobre o absurdo em Praga e na segunda se encontra em comunhão com o mundo na Itália. Nós observaremos o quanto essa estrutura bipartida foi importante para a escrita de L'Étranger.

O ensaio "Amour de vivre" também faz uma referência a uma viagem empreendida às ilhas Baleares que ele faz no verão de 1935. Nesse caso, podemos nos perguntar por que Camus inverteu a cronologia das viagens na ordem dos textos. Quilliot responde que é porque sem dúvida "l'endroit" das coisas sai de "l'envers": "Cronologicamente Praga se sucede à Palma; mas na cronologia moral de Camus, a derrota de Praga sucede-se um frenesi de viver, uma veemência sensual que anuncia "Amour de vivre". ${ }^{29}$ Haveria assim uma relação de avesso e de direito mesmo entre os ensaios: não pode haver amor de viver sem desespero de viver (EE, 2007, p. 107).

No último ensaio, “L'Envers et L'Endroit”, encontramos novamente uma estrutura que se divide entre a imagem da morte e do outro lado a beleza e a luz do mundo. Esse ensaio é uma espécie de resposta e conclusão a todos os anteriores: entre esse direito e esse avesso do mundo não há possibilidade de escolha (EE, 2007, p. 118). Essas duas ideias são complementares e inseparáveis.

A partir desses apontamentos, podemos observar que L'Envers et L'Endroit (e todos os escritos anteriores a ele) faz parte de um caminho que chegará a Le Mythe de Sisyphe e L'Étranger, por isso o fato de não ser incluídos em nenhum ciclo. Esses ensaios fazem parte da reflexão que levou até a escrita do ensaio Le Mythe de Sisyphe: nesses primeiros textos a reflexão sobre o absurdo está ainda em “estado bruto". É somente no ensaio de 1942 que ele será nomeado e passará a ser uma noção patente no pensamento de Camus. Esse é um traço da reflexão e da

\footnotetext{
${ }^{29}$ Chronologiquement, Prague succédait à Palma; mais dans la chronologie morale de Camus, à la débâcle de Prague allait succéder une frénésie de vivre, une véhémence sensuelle qu'annonce "Amour de vivre." (QUILLIOT, 2000, p.1178)
} 
escrita camusiana: a revolta, que será o tema do segundo ciclo, já estava presente em Le Mythe de Sisyphe. Assim, todos os escritos são costurados por um mesmo fio e, nessa costura, é o movimento repetitivo efetuado pela agulha da escritura que seduz o leitor.

Esses ensaios, porém, não somente fazem parte do percurso reflexivo que levou até Le Mythe de Sisyphe. Da mesma maneira, eles contêm um aspecto narrativo que faz parte do percurso romanesco, que culmina com a publicação do primeiro romance de Camus.

Para melhor observamos esse trajeto escolhemos o tema da relação entre a mãe e o filho, também personagens do drama do absurdo. Esse tema perpassa todos os escritos e é fundamental para a narrativa, uma vez que o texto se inicia pela morte da mãe e pela indiferença do filho, tema cristalizado no conhecido incipt:

Aujourd'hui, maman est morte. Ou peut-être hier, je ne sais pas. J'ai reçu un télégramme de l'asile: "Mère décédée. Enterrement demain. Sentiments distingués. Cela ne veut rien dire. C'était peut-être hier. (Et, 1996, p. 9$)^{30}$

\subsection{A circulação de um tema}

A primeira vez que esse tema aparece nos escritos de Camus é em um texto datado de 1934, intitulado "Les voix du quartier pauvre”, que figura nos Écrits de Jeunesse (1973, p. 271).

A primeira dessas vozes é a da "mulher que não pensava": o narrador descreve a relação entre uma mãe doente e calada e um filho que a amava. Essa relação é impossibilitada pelo silêncio da mãe, o que faz com que o filho experimente um estranho sentimento. ${ }^{31}$ Esse estranho sentimento que o filho tem pela mãe é descrito em 1935 nos Carnets como aquilo que constitui toda a sua sensibilidade (C I, 1962, p. 16). Nessa mesma nota, encontramos um plano para uma possível narrativa, que tem como centro a relação com a mãe: “1) Um cenário, o bairro e seus moradores. 2) A mãe e seus atos. 3) A ligação do filho à mãe.”.

A intriga de "Les Voix" será reaproveitada para a escrita de um romance ao qual Camus nunca fez alusão. Segundo Lévi-Valensi, ele pode ser datado possivelmente entre os anos de

\footnotetext{
30“Hoje, minha mãe morreu. Ou talvez ontem, não sei bem. Recebi um telegrama do asilo: "Sua mãe falecida. Enterro amanhã. Sentidos pêsames". Isto não quer dizer nada. Talvez tenha sido ontem.” (Et, 1979, p. 155)

${ }^{31}$ Esse estranho sentimento despertado na relação com a mãe guarda também relações com o sentimento de estranheza descrito em Le Mythe de Sisyphe, tema que será aprofundado no segundo capítulo.
} 
1934 e $1936 .{ }^{32}$ Em suas pesquisas aos arquivos do escritor, ela conseguiu reconstruir em parte essa narrativa através de fragmentos esparsos de manuscritos cujo tema principal é a relação do filho com a mãe. A única diferença que podemos observar em relação a "Les Voix" é que esse romance tira sua unidade de um personagem central: "Louis Raingeard" (2006, p. 207). Nessa mesma época, o texto de "Les Voix" será da mesma forma inteiramente reaproveitado para a escrita do ensaio “Entre oui et non" que Camus publica em L'Envers et L'Endroit, mas eliminando a presença desse personagem nomeado.

Como sabemos, a relação entre a mãe e o filho será fundamental para L'Étranger. No entanto, essa narrativa inclui um novo elemento que ainda não havia aparecido antes: a morte da mãe.

Nesses primeiros textos, temos somente a narrativa da morte da avó do personagem ("Le Courage", de 1934, e o ensaio "Entre oui et non"). Esse tema aparecerá pela primeira vez em outra tentativa de romance, La Mort Heureuse, que ele escreve por volta de 1936 e 1937 . O uso que Camus faz desse tema é muito particular, uma vez que o tema da morte da mãe se expande e, de uma pequena passagem em La Mort Heureuse, ele se transforma em todo um capítulo em L'Étranger. Na segunda parte da narrativa o tema da relação com a mãe será central, pois servirá a acusação do processo de Meursault, se sobrepondo mesmo ao assassinato que ele comete. Esse tema é, portanto, aquele que abre e que fecha o livro. Dessa forma, podemos elaborar o seguinte esquema em relação ao movimento desse tema desde a primeira vez em que aparece até a elaboração de L'étranger:

\footnotetext{
${ }^{32}$ Entre esses mesmos manuscritos em que Lévi-Valensi encontra, o romance é encontrado num plano que parece expandir a nota de 1935 :

I. O B[airro] P[obre]

Cap. I O ponto de crise

Cap. II A lenta desagregação que colocou essa mulher face a face com seu filho

Morte da avó

Doença do filho

Separação do irmão [...]

II. A M[ãe] e o F[ilho]

Primeiro ponto de compreensão

Atração incurável

III. O último abrigo

Retorno ao ensaio: 8 dias (LÉVI-VALENSI, 2006, p. 211)
} 


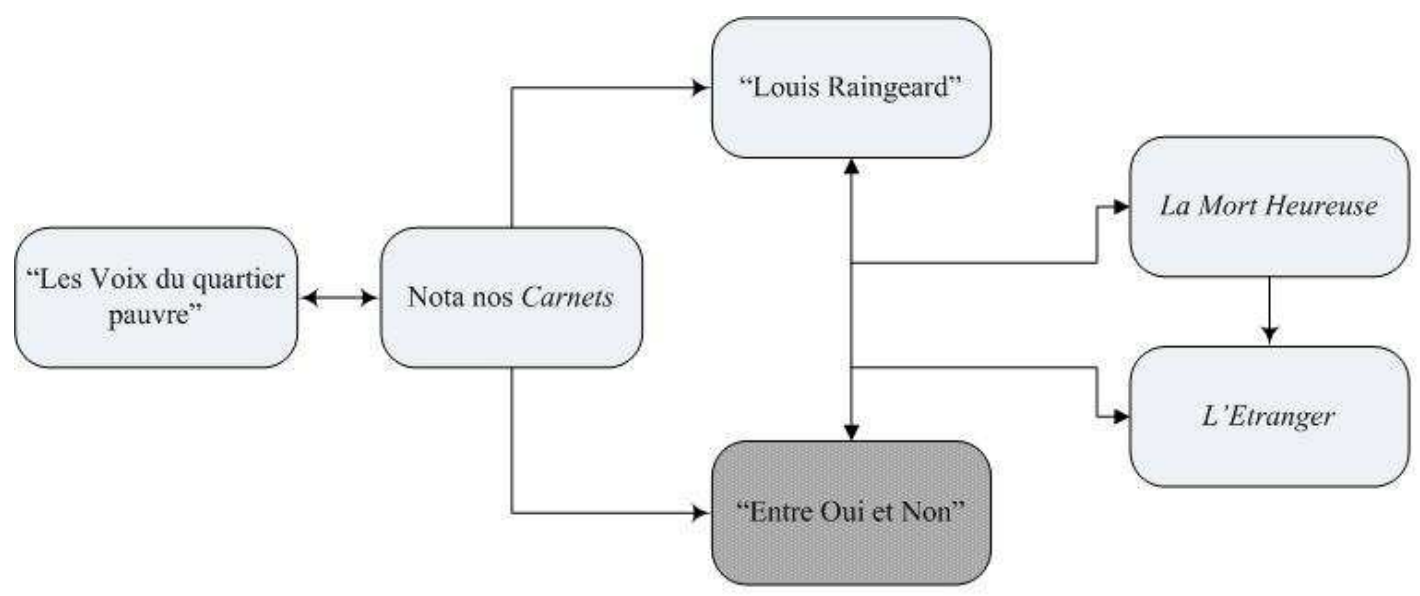

A essas primeiras tentativas de escrita romanesca, Lévi-Valensi chamou de ciclo "Louis Raingeard/L'Envers et L'Endroit', uma vez que ela encontra esse esboço de romance exatamente entre as folhas preparatórias para o ensaio. Esse fato coincide com o processo que analisamos acima: a circulação de temas entre diferentes projetos literários concomitantes, em que uma mesma ideia ou uma mesma nota serve para a escritura de diferentes textos. No universo do processo de criação, essas partículas dispersas aqui e ali se coagularam em um texto ${ }^{33}$ e ocuparam seu lugar definitivo em L'Étranger.

\footnotetext{
${ }^{33}$ Perguntado sobre seu processo de criação, Camus responde : "Des notes, des bouts de papier, la rêverie vague, et tout cela des années durant. Un jour, vient l'idée, la conception, qui coagule ces particules éparses." (E, 2000, p. 1921)
} 


\section{Uma unidade que se ignorava}

O processo de criação de uma obra literária é o campo de estudo da crítica genética. Essa disciplina surge na França no final dos anos sessenta, quando um grupo de linguistas, tomando contato com os manuscritos de Heine que chegam à Biblioteca Nacional da França (BnF), vislumbram a possibilidade de estudar o processo de criação com base nesses documentos. A disciplina se institucionaliza em 1982, com a criação do Institut de Textes et Manuscrits Modernes (ITEM), onde diversos grupos se organizam para estudar o acervo de grandes escritores franceses, como Flaubert, Zola, Proust e Sartre. Em 1994, Almuth Grésillon publica Élements de Critique Génétique, obra que procura introduzir e sistematizar o método da crítica genética. Esta chega ao Brasil na década de oitenta, sendo introduzida por Philippe Willemart, que possui diversas publicações na área, principalmente estabelecendo relações entre a crítica genética e a psicanálise. Ao longo dos anos, a disciplina ganha novos contornos e, em 2007, Claudia Amigo Pino e Roberto Zular publicam o livro Escrever sobre escrever,cujo subtítulo poderia resumir os rumos que a crítica genética tem tomado no país, "uma introdução crítica à crítica genética". O objetivo desse livro "não [é] descrever uma disciplina positiva, sem conflitos, porque não é o que se pode observar desses trinta anos de prática. Mais que fechar e convencer, nosso objetivo aqui foi abrir e problematizar."(PINO e ZULAR, 2007, p. 2). Nosso trabalho se insere nessa linha, visto que nele problematizamos alguns aspectos da metodologia da crítica genética.

Quando se fala em crítica genética, a primeira coisa que nos vem à mente é o estudo de manuscritos. Eles impõem limites materiais à disciplina, pois não seria possível estudar o processo de criação se não existissem traços escritos dessa gênese. Para Grésillon, essa limitação objetiva serviria de proteção contra toda especulação abstrata sobre a criação $(2007$, p. 40).

Mas o que fazer quando não temos acesso a esses manuscritos ou se eles não estão disponíveis para pesquisa? Ou, então, se podemos ter acesso a eles, mas de uma forma diferente? A resposta a essas perguntas encontra-se na discussão da especificidade do nosso material.

Em primeiro lugar, nosso objetivo não é analisar os manuscritos de L'Étranger: não temos acesso aos planos, rascunhos, versões manuscritas ou datilografadas. A grande maioria dos manuscritos de Camus pode ser consultada no CDAC (Centre de Documentation Albert Camus) 
na biblioteca pública Méjanes de Aix-en-Provence. ${ }^{34}$ Esses documentos, conservados quase que em sua totalidade, representam uma grande riqueza, explorada principalmente por pesquisadores estrangeiros. $^{35}$ No entanto, têm despertado pouco interesse na área dos estudos da crítica genética, visto que não existe uma equipe que se concentre no estudo desses manuscritos nem foram encontrados até o momento livros ou artigos utilizando-se dessa disciplina para analisá-los.

Os estudos mais relevantes e conhecidos foram duas teses que posteriormente tornaram-se livros: a primeira delas de André Abbou, “Genèse et édition critique de L'Étranger", de 1970, cujas notações foram recuperadas na edição da Pléiade, e o trabalho de Jacqueline Lévi-Valensi, de 1981, publicado em 2006 sob o título de Albert Camus, La naissance d'un romancier, mas que não se utilizam diretamente da metodologia da crítica genética.

O objetivo de nosso trabalho é estudar alguns aspectos do processo de criação de L'Étranger à luz dos textos anteriores, ${ }^{36}$ tenham eles sido publicados (é o caso de L'Envers et L'Endroit e Noces) ou não pelo autor. ${ }^{37}$

Entre esses textos não publicados em vida por Camus podemos citar aqueles que foram escritos entre os anos de 1931 a 1935, e que foram reunidos na coletânea Écrits de Jeunesse, publicada por Paul Viallaneix em 1973. Segundo Lévi-Valensi, nenhum desses textos parece atingir o apuramento formal daqueles que seriam posteriormente publicados: nesses primeiros anos as tentativas de escrita são aparentemente fragmentadas e desordenadas.

\footnotetext{
${ }^{34}$ Os arquivos que estavam em poder da família de Camus foram inicialmente arquivados no IMEC (Institut Mémoires de l'Édition Contemporaine). Em 2001 foram transferidos para a biblioteca Méjane, na cidade de Aix-enProvence, sendo criado o Fonds Albert Camus, que é composto por dois conjuntos de documentação, com condições distintas de acesso: um conjunto consultável no CDAC e outro na sala Peiresc (onde podem ser consultados os fundos patrimoniais). No CDAC, há inventários, impressos, dossiês de imprensa, trabalhos universitários e uma exposição permanente. Na sala Peiresc podem ser consultados os manuscritos, os datiloscritos, a correspondência e alguns impressos. Essa consulta depende de uma autorização do depositário, no caso a filha do escritor, Cathérine Camus. O Fundo também conta hoje com os trabalhos preparatórios de Olivier Todd para sua obra Albert Camus: une vie, publicado pela Gallimard, em 1996, e com um depósito complementar de arquivos até então conservados por Cathérine Camus. Disponível em: <http://www.citedulivreaix.com/Typo3/fileadmin/documents/Expositions/centrecamus/historique.htm>. Acesso em: 17 maio 2011.

${ }^{35}$ Cf. "À Aix, le fonds Albert Camus n'attire pas les chercheurs français". Disponível em: <http://actu.voila.fr/actualites/dossier/>. Acesso em: 17 maio 2011.

${ }^{36}$ Reportamo-nos aqui à discussão proposta por Pino e Zular no tópico "É preciso ter acesso aos manuscritos originais?" (2007, p. 101) e, mais particularmente,à ideia apresentada por Willemart (2004) de que crítica genética pode ser feita sem o acesso aos manuscritos.

${ }^{37}$ Antes e depois da publicação das duas reuniões de ensaios Camus escreve diversos textos que não publica e que permanecem em estado de manuscrito. Para Grésillon, os manuscritos são objetos escritos para serem lidos por ninguém; muitos escritores insistiram sobre o aspecto privado de sua escrita. A pergunta que ela se coloca é porque eles conservam esses manuscritos. É a partir desse paradoxo que a crítica genética deve sua existência (2007, p.45).
} 
Em nossa análise, também nos remetemos a romances que Camus abandona. O primeiro deles, já aqui citado, é "Louis Raingeard". São cerca de cinquenta páginas manuscritas e que nunca chegaram a um estado mais acabado. Lévi-Valensi pontua a retomada dos mesmos temas sob formas diferentes, a utilização das mesmas histórias ou das mesmas frases atribuídas a personagens diferentes; a busca de títulos e de planos evidencia que o trabalho de organização não foi completado (2006, p. 206). Na nova edição da Pléiade, Lévi-Valensi nos apresenta uma transcrição desse documento.

A segunda narrativa é La Mort Heureuse, um texto acabado, mas que só foi publicado postumamente em 1971, nos Cahiers Albert Camus I. Como ressalta Sarocchi em uma nota inicial ao texto, a publicação desses documentos inéditos foi uma decisão da família e dos editores de Camus. Sobre o porquê de publicar uma obra que o autor não deu a conhecer a seu público, Sarocchi comenta que Camus não publicava nada descuidadamente, mas que, quando gostamos de um escritor ou o estudamos com profundidade, desejamos conhecer tudo que ele escreveu (1971, p. 5). E esse texto é especialmente importante pelas relações que guarda com L'Étranger. A primeira semelhança que podemos notar entre La Mort Heureuse e L'étranger é o nome de sua personagem principal, Mersault. Sabemos que o protagonista da segunda narrativa se chama Meursault com um $u$ a mais, no entanto, este aparece apenas no final do manuscrito n. 1 de L'étranger, tal como nos descreve Quilliot, que teve acesso aos manuscritos (1962, p. 1913). Além desse, mais nomes e personagens se repetem em ambas as narrativas. Da mesma forma, ambas possuem duas partes divididas por uma morte. Para Quilliot, a semelhança dessas narrativas vai além da repetição de nomes: "Meursault é exatamente o irmão mais novo de Mersault; a mesma transparência, a mesma indiferença, a mesma disponibilidade, que tomaríamos por cinismo em La Mort Heureuse, e que se torna, em L'Étranger, o gosto da verdade." ${ }^{38}$ Essa relação fica ainda mais explícita quando observamos que trechos da primeira narrativa são transpostos para L'Étranger.

Por fim, também fazemos uso dos cadernos que Camus escreveu entre os anos de 1935 e 1942, publicados sob o nome de Carnets I. O escritor sustentou essa prática até sua morte. Os seis primeiros cadernos, de maio de 1935 a março de 1951, foram publicados sob os cuidados de Roger Quilliot. Camus mesmo datilografou e corrigiu parcialmente os sete primeiros. Os

\footnotetext{
${ }^{38}$ Meusault est bien le frère cadet de Mersault; c'est la même transparence, la même indifférence, la même disponibilité, qu'on prendrait pour du cynisme dans La Mort heureuse, et que devient, dans L'étranger, le goût même de la vérité" (QUILLIOT, 1962, p.1913).
} 
cadernos sete, oito e nove - de março de 1951 a dezembro de 1959 - só foram publicados em 1989. Esses cadernos nos interessam porque antes de tudo eles são um instrumento de trabalho: ${ }^{39}$ Camus anota projetos, rascunhos, frases copiadas ao longo de leituras, um material que encontramos depois em seus livros (GRENIER, 1990, p. 27).

Diante desse quadro, podemos afirmar que temos acesso a alguns manuscritos, mas esses são versões transcritas e publicadas. A pergunta que se coloca diz respeito ao estatuto desses textos: trata-se realmente de manuscritos? Grésillon nota que, uma vez publicados, os manuscritos fazem progressivamente parte da literatura:

Certamente, não serão confundidos com a obra e conservarão sua natureza de documento de trabalho, mas integrados na rede de troca e de circulação social, perderão um pouco seu valor de fetiche para se tornarem, efetivamente, como os outros livros, objetos culturais. [...] Uma vez publicados os manuscritos, tornados objetos de leitura e de crítica, não existirá mais o aparente paradoxo de uma "literatura sem leitor". (2007, p. 46)

Essa é também a posição de Barthes, para quem é indiferente dizer literatura, escritura ou texto, pois, enfim, todos fazem parte da prática de escrever (1988, p. 15). E são exatamente os traços dessa prática que desejamos seguir: todos esses textos anteriores, sejam manuscritos ou não, tenham sido publicados ou não, são importantes para o estudo de vários aspectos referentes a elaboração de L'Étranger.

Esse tipo de abordagem em crítica genética foi nomeado por Willemart como uma leitura "só depois". Leitura na qual buscamos uma unidade ulterior entre os textos, ou, nas palavras de Proust, uma "unidade que se ignorava" (2008, p. 235). A esse respeito, Willemart comenta que "Proust escreveu em dois livros, Jean Santeuil e Contre Sainte-Beuve, um esboço de romance que publicou no Em Busca do Tempo Perdido, as situações são várias vezes as mesmas e as personagens, embora com nomes diferentes, reaparecem. Mas é esse último livro que ordena os primeiros e permite entender os processos de criação do narrador.” (2009, p. 63) Sustentamos que um fenômeno parecido com esse ocorre no processo de criação camusiano: para nós L'Étranger é esse ponto que irá ordenar tudo o que foi escrito antes. ${ }^{40}$

\footnotetext{
${ }^{39}$ Para um aprofundamento na relação entre os cadernos e o processo de criação recomendamos o livro Carnets d'écrivains (1990), mais particularmente a introdução escrita por Louis Hay: "L'amont de l'écriture".

${ }^{40}$ Para tratar desses escritos nos reportaremos, sempre que necessário, ao estudo empreendido por Jacqueline LéviValensi (2006). No entanto, destacamos nossa diferença com relação ao seu trabalho: como ela explica na introdução de seu livro, seu objetivo é mais geral ao depreender desses escritos anteriores a gênese da obra romanesca de
} 
Para Proust, essa unidade ulterior é principalmente de natureza temática, em carta à René Blum, ele comenta seu processo de criação: "[...] do ponto de vista da composição, ela é tão complexa que só aparece tardiamente quando os "temas" começaram a se combinar."41

Almuth Grésillon, em "Proust ou l'écriture vagabonde" elege o tema da matinée para analisar a escritura proustiana. Partindo da "Matinée chez la Princesse de Guemantes" do último volume de La Recherche, a pesquisadora mostra como esse tema já estava presente desde o início em Contre Sainte-Beuve e em Jean Santeuil. Ele se repete também em todos os volumes da Recherche e se torna o motor de toda a ação romanesca. Mais que isso, o tema da matinée é um espécie de estrutura profunda que organizará o texto romanesco e o eixo a partir do qual se orienta todo o processo de escritura de 1908 até a morte do autor. Grésillon ressalta que o que interessa para a crítica genética não é o fato de que esse tema esteja presente desde o início, mas que ele se transforma, se expande, se desloca, obedece a novos princípios e representa uma espécie de fil rouge $e^{42}$ da escritura. Pensando na unidade ulterior, Grésillon escreve:

Eu gostaria, portanto, concluir não nessa "manhã original”, mas na última matinée da Recherche, para a qual todas as outras convergem. No fim de Le Temps Retrouvé a matinée aparece em sua verdadeira função: ela culmina esteticamente na tomada de consciência e na concretização da vocação literária. Deste ponto de vista, todas as matinées da Recherche nada mais são que signos anunciadores do ato de escrita, este ato criador que através de reminiscências noturnas e devaneios matinais, foi incessantemente adiada. (1996, p.123 tradução nossa)

Assim, por meio dos temas, a noção de "unidade ulterior" empregada na crítica genética está muito próxima da abordagem feita pela crítica temática, tal como apresentada por Poulet, e da qual ele identifica o próprio Proust como fundador.

Para o crítico, quando lemos algum volume isolado de um autor do qual nada conhecemos, não reconhecemos nada, não sabemos como distinguir o que importa do que é fortuito. Somente a percepção de formas similares em circunstâncias novas pode nos revelar que esses traços têm algo de essencial. Assim, criticar é se lembrar, ${ }^{43}$ escreve Poulet. $\mathrm{O}$ ato crítico por

Camus: de L'Étranger a Le Premier Homme. Nosso objetivo é, utilizando-nos das conclusões de Lévi-Valensi, fazer o caminho contrário, ou seja, pensar esses escritos a partir de L'Étranger, nosso objeto central.

${ }^{41}$ À René Blum, [23 février 1913], Correspondance., t. 12, éd. cit., p. 92 apud PIERROT, 2007.

${ }^{42}$ Fio condutor, elemento repetitivo que reaparece regularmente em uma narrativa e dá coerência a um conjunto.

${ }^{43}$ Discorrendo sobre o processo de criação proustiano, Hulle afirma que, em seus escritos, Proust não se contenta somente em explicar esse princípio de "memória involuntária", mas ele o coloca em prática: durante o processo de 
excelência é aquele pelo qual, através da totalidade de uma obra, descobrimos retrospectivamente as frequências significativas e as obsessões reveladoras.

É exatamente essa unidade ulterior que encontramos nos escritos camusianos: uma unidade temática. Essa unidade tardia, mas iluminadora, é, portanto o avesso e o direito e aparece através da repetição de dois temas fundamentais dos Écrits Jeunesse a L'Étranger: as núpcias e o absurdo.

Como reflete Camus dois anos antes de sua morte, "a obra de um homem não é nada mais do que esse longo caminho para reencontrar as duas ou três imagens simples e grandes para os quais o coração uma vez se abriu" (EE, 2007, p. 31). Esse é também o objetivo do crítico, o de reencontrar através dessa leitura total os temas que estavam lá desde o início. A diferença está apenas no fato de que, no caso da crítica genética, o leitor tem acesso aos manuscritos e, a partir dessa leitura, ele também pode reconhecer essa unidade ulterior entre os escritos. Esse fato faz com que toda questão se concentre em um processo, não aquele pelo qual necessariamente o escritor passou, mas aquele que o pesquisador construiu a partir de sua leitura (PINO; ZULAR, 2007, p. 31).

Discorrendo ainda sobre a noção de "unidade ulterior", podemos encontrá-la na própria leitura tardia que Camus faz de sua obra no prefácio de 1958. Passaram-se vinte anos desde a publicação de L'Envers et L'Endroit: após esse, Camus escreveu muitos outros livros, mas isso não significou para ele um verdadeiro progresso. Desse primeiro livro até Le Premier Homme romance que ele já escrevia por volta de 1958 e que é interrompido por sua morte em 1960 - são os mesmos temas e as mesmas imagens que esse tema maior, o avesso e o direito, gerou:

Qu'importe! Je voulais seulement marquer que, si j'ai beaucoup marché depuis ce livre, je n'ai pas tellement progressé. Souvent, croyant avancer, je reculais. Mais, à la fin, mes fautes, mes ignorances et mes fidelités m'ont toujours ramené sur cet ancien chemin que j'ai commencé d'ouvrir avec L'Envers et L'Endroit, dont on voit les traces dans tout ce que j'ai fait ensuite [...] (EE, 2007, p. 28) ${ }^{44}$

leitura alguns fragmentos textuais vêm à superfície, o que pode provocar no leitor um clarão de reconhecimento (HULLE, 2008).

${ }^{44}$ Que importa! Queria apenas acentuar que, se caminhei muito desde desse livro eu não progredi tanto. Muitas vezes, supondo avançar, recuava. Mas, por fim, as minhas culpas, as minhas ignorâncias e as minhas fidelidades voltaram sempre a trazer-me ao antigo caminho que comecei a abrir com $O$ Avesso e o Direito, de que se vêem os vestígios em tudo o que fiz depois (EE, 2007, p. 28) 
Através dessa nota, podemos levantar a hipótese de que o processo de criação de Camus não se faz através de um movimento linear ou mesmo circular, como poderia nos indicar a ideia de ciclo. Se pensarmos nessa unidade ulterior, ou seja, em todos os textos que ele escreve antes de L'Étranger, devemos substituir o processo circular por um processo em espiral (que sintetiza ao mesmo tempo o movimento linear e circular). ${ }^{45}$

A espiral pode ser definida como um ponto móvel que gira a partir de um ponto fixo, afastando-se ou aproximando-se dele. Camus entende o processo de criação exatamente como um movimento dessa natureza:

[...] que tout écrivain se répète en même temps qu'il progresse, que l'évolution d'une pensée ne se fait pas en ligne droite, qu'elle soit ascendante ou non, mais selon une sorte de spirale, où la pensée repasse par d'anciens chemins sans cesser de les surplombler. (E, 2000, p. 1615)

Esse movimento se dá principalmente quando o escritor se utiliza de formas diferentes para tratar da mesma imagem ou do mesmo tema: ensaios, reflexões filosóficas ou narrativas. ${ }^{47}$ Isso significa que nessa espiral incluem-se não somente os temas que se reiteram, mas também a utilização tanto da escrita literária quanto da reflexão filosófica. Por esse motivo, Camus negava que houvesse uma evolução na passagem de L'Étranger, publicado alguns meses antes, para Le Mythe:

Je ne suis nullement passé de l'oeuvre d'imagination à l'ouvrage de morale. Le thème qui m'interéssait avant la guerre, je l'ai traité sous trois formes différentes: l'essai avec Le Mythe de Sisyphe, le roman avec L'Étranger, le théâtre avec Le Malentendu et Caligula. [...] Loin qu'il ait évolution dans aucun cas il y a au contraire obstination à présenter dans de genres différents des visages particuliers d'une même oeuvre ou d'une même entreprise. (E, 2000, p. 1614)

\footnotetext{
${ }^{45}$ Reportamo-nos aqui a discussão feita por Zimmermmann no artigo "La spirale: forme de pensée de la création": "Andrej Belyi, le plus important poète, écrivain et théoricien symboliste, fils du mathématicien Andrej Bugaev, dans son essai Saintes couleurs (Svjaščennye cveta, 1903), lit les formes géométriques fondamentales comme des formes du temps : la ligne droite représente l'écoulement linéaire du temps; le cercle, l'éternel retour ; la spirale, comme synthèse de la droite et du cercle, la réunion des temps linéaire et cyclique.”.Disponível em: <http://www.item.ens.fr/index.php?id=223367>. Acessado em 17 maio 2011.

46 “[...] que todo escritor se repete ao mesmo tempo que progride, que a evolução de um pensamento não se faz em linha reta, seja ascendente ou não, mas segundo uma espécie de espiral por onde o pensamento repassa pelos caminhos antigos sem deixar de ultrapassá-los."

${ }^{47}$ Nos reportamos aqui a discussão proposta por Lévi-Valensi em "La relation au réel dans le roman camusien": "Tout l'oeuvre de Camus, qui reprend sans cesse les mêmes éléments, les mêmes thèmes, les mêmes images, mais pour de créations à chaque fois différentes, épouse la forme de la spirale" (1982, p. 156).

${ }^{48}$ “Eu não passei de modo nenhum da obra de imaginação para a obra de moral. O tema que me interessava antes da guerra, eu o abordei sob três formas diferentes: o ensaio com Le Mythe de Sisyphe, o romance com L'Étranger, o
} 
A espiral é, assim, uma figuração espacializada do que Camus chama de obstinação: essa repetição que comporta o passado e separa-se dele englobando cada experiência nova e integrando-a ao movimento contínuo e repetitivo (LÉVI-VALENSI, 2006, p. 497).

Esse processo em espiral pode ser particularmente observado na relação entre L'Étranger e Le Mythe de Sisyphe: nos dois textos o absurdo se repete como um tema, mas em cada um ele é tratado de forma distinta. Essa escrita, cujo eixo temático se apresentaria sob diferentes planos da criação, já estava prevista entre as primeiras notas Carnets: "uma obra filosófica e uma obra literária sobre a absurdidade [...]" (C I, 1962, p. 40). Assim, a questão que se coloca para todos aqueles que refletem sobre o pensamento camusiano é a seguinte: por que expressar a mesma coisa, mas de maneiras diferentes $?^{49}$

teatro com Le Malentendu e Caligula. [...] Ao contrário de haver uma evolução, há sim uma obstinação em apresentar, através de diferentes gêneros, as facetas particulares de uma mesma obra ou de uma mesma empresa."

49 Aqui nos reportamos a discussão de Franklin Leopoldo e Silva sobre a relação entre filosofia e literatura nos escritos sartrianos: "[...] a expressão filosófica e a expressão literária são ambas necessárias em Sartre porque, por meio delas, o autor diz e não diz as mesmas coisas. Parece óbvio afirmar que Sartre diz a mesma coisa quando faz filosofia e quando faz literatura, mas isso deixa ainda intacta a questão de por que ele o diz de duas maneiras diferentes" (2004, p. 12). 


\section{Literatura e Filosofia: o avesso e o direito da escritura}

Para começar a responder a questão anteriormente proposta, devemos retomar a nota já citada: "uma obra filosófica e uma obra literária sobre a absurdidade, nas duas misturar os dois gêneros respeitando o tom particular." (C I, 1962, p. 40).

A partir dela compreendemos, em primeiro lugar, que para Camus é possível misturar filosofia e literatura. Por que então ele não escreveu uma só obra em que essas duas disciplinas se juntassem, mas decidiu escrever duas? Porque para o escritor é necessário que se guarde o tom particular de cada obra. Assim, Le Mythe é necessário, pois mistura filosofia e literatura, mas respeitando o tom da filosofia, assim como L'Étranger, que mistura literatura e filosofia, mas respeita o tom da literatura. ${ }^{50}$

Em Le Mythe de Sisyphe, Camus afirma a arbitrariedade da antiga oposição entre filosofia e literatura. Para o escritor, a única argumentação válida para afirmar essa oposição está na contradição entre o filósofo encerrado no meio do seu sistema e o artista colocado diante de sua obra. Por oposição ao artista, o filósofo jamais criou vários sistemas, mas isso é verdade também na medida em que nenhum artista expressou mais que uma única coisa sob diversas facetas (MS, 2008, p. 133). Dessa forma, Camus aproxima o criador do filósofo. Finalmente, ele conclui que é inútil discutir as distinções de método e de objeto se estamos convencidos da unidade das metas do espírito: "Não há fronteiras entre as disciplinas que o homem emprega para compreender e para amar. Elas se interpenetram e a mesma angústia as confunde.” (MS, 2008, p. 112). ${ }^{51}$

\subsection{A evidência e o lirismo: os ensaios}

No entanto, ao longo da história, filosofia e literatura foram consideradas como duas formas de atividade distintas. Segundo Philippe Sabot (2002), filosofia e literatura não se utilizam dos mesmos instrumentos e não buscam um mesmo fim. Enquanto o texto filosófico tira valor de sua pertinência conceitual e de uma argumentação coerente e sistematizada, o texto literário

\footnotetext{
${ }^{50}$ Sobre essa questão ver a abordagem de Souza a respeito da relação entre filosofia e literatura em Sartre: "Não podemos estabelecer uma superioridade da filosofia em relação a literatura e nem desta em relação àquela: o que temos é uma interdependencia entre elas, baseada na insuficiência de cada uma (enquanto a prosa retrata sem conceitualizar, a filosofia conceitualiza sem retratar)." (2008, p. 73).

51،'Il n'y a pas de frontières entre les disciplines que l'homme se propose pour comprendre et aimer. Elles s'interpénètrent et la même angoisse les confond.” (MS, 2008, p.133)
} 
recebe seu valor de sua unidade de estilo e da qualidade de sua escritura. Por isso, não se espera que o texto literário forneça a seu leitor uma filosofia, nem que os filósofos se preocupem com a beleza de seus raciocínios.

Segundo Campion (1996, p. 10), porém, os Pensées de Pascal se configuram como uma das raras obras em que as duas disciplinas se misturam, erguendo um protesto contra a separação histórica entre filosofia e literatura. É exatamente nessa tradição que Camus se insere.

Em seu livro Albert Camus: um elogio do ensaio, Costa Pinto mostrará que o escritor insere-se na linhagem de ensaístas franceses como Montaigne, Pascal e La Rochefoucauld ao explorar o ensaio como um gênero que está no limite entre a reflexão filosófica e a invenção literária.

Essa concepção de mistura entre os gêneros já havia sido explorada nos ensaios L'Envers et L'Endroit. ${ }^{52}$ Neles, Camus marca que filosofia e literatura podem se interpenetrar. ${ }^{53}$ Por exemplo, no ensaio "L'Envers et L'Endroit" o narrador conta a história de uma velha senhora que recebera uma pequena herança. Ela aplicara todo o dinheiro na compra de um túmulo para si mesma, o qual visitava todos os domingos. No final, o narrador insere uma reflexão no texto: "A grande coragem é ainda a de ter os olhos abertos para a luz como para a morte.” (EE, 19- ?, p. 110). ${ }^{54}$ Aqui, narrativa e reflexão se conjugam para nos ensinar que a morte é uma certeza e que é preciso conservar a lucidez até o fim. Para Costa Pinto,

em sua estrutura ao mesmo tempo ensaística e narrativa, os textos de $O$ Avesso e $o$ Direito antecipam assim o dispositivo estilístico que determinará tanto a ficção de Camus quanto seus ensaios: todas as ações (das personagens) ou as reflexões (do moralista) tornam à condição do homem frente ao imobilismo indiferente do mundo. (1996, p. 166)

\footnotetext{
${ }^{52}$ É muito provável que essa compreensão tenha se dado muito cedo no escritor, uma vez que a estrutura literatura/filosofia já havia aparecido em seus primeiros escritos. Em "Devant la morte" e "Perte de l'être aimé", textos de 1933, Camus escreve sobre o mesmo tema: a morte do ser amado. O primeiro aparece na forma de uma narração e explora principalmente o tema da comédia social ligada ao rito funerário. O segundo aparece em forma de uma reflexão sobre essa perda e sobre a dor.

${ }^{53}$ Remetemos o leitor para duas interessantes análises de L'Envers et L'Endroit. Para um aprofundamento da relação entre as passagens narrativas e reflexivas nos ensaios recomendamos o capítulo "Entre l'essai et le récit" de LéviValensi (2006) e o artigo 'L'Ironie 'tapie au fond des choses'ou l'inextricable texture de L'Envers et L'Endroit",de Françoise Armengaud (1997), para pensar a relação profunda entre filosofia e literatura nos ensaios.

54،"Le grand courage, c'est encore de tenir les yeux ouverts sur la lumière comme sur la mort." (EE, 2007, p.119)
} 
Os ensaios de L'Envers et L'Endroit são, porém, muito mais literários que reflexivos. Essa inclinação é possível porque o ensaio não é um gênero definido, mas um gênero de intervalo, de passagem (PINTO, 1996, p. 89).

Em Le Mythe de Sisyphe, Camus se utilizará do ensaio, mas dessa vez com maior inclinação para reflexão filosófica. Essa forma serviu precisamente a ele que nunca se considerou como um filósofo, ou seja, que jamais poderia utilizar a forma do tratado. Interrogado sobre sua relação com o existencialismo, ${ }^{55}$ Camus responde:

$\mathrm{Na}$ verdade, poucas pessoas sabem exatamente o que é o existencialismo. Assim se explicam bem as coisas. Tudo o que posso dizer de minha parte é que: eu não sou um filósofo. Eu não creio suficientemente na razão para acreditar em um sistema. O que me interessa é saber como se conduzir. Mais precisamente como se conduzir quando não se crê nem em Deus nem na razão. ${ }^{56}$

Sua descrença na razão o impede de escrever de outra forma. Essa concepção de escrita provém da própria noção de absurdo que, antes de tudo, é contrário à razão. Em uma nota introdutória a Le Mythe, Camus escreve que: "As páginas que se seguem tratam de uma sensibilidade absurda [...] e não de uma filosofia absurda [...]". 57

Assim, para Camus ser filósofo não significa criar um sistema de explicação, mas colocarse diante das questões essenciais inerentes à nossa condição (LÉVI-VALENSI, 1997, p. 29).

Essa descrença também influencia os temas e a linguagem que ele utilizará em seu texto. Guimarães da Silva (2001), discorrendo sobre a relação entre filosofia e literatura em Platão e Camus, e refletindo principalmente sobre Le Mythe de Sisyphe, afirma que os temas do ensaio não são comuns dentro da tradição do pensamento filosófico: absurdo, amor, suicídio, silêncio, lucidez, literatura. O estilo também é contrário àquele do tratado: o texto é rico em imagens e lirismo e sua linguagem muitas vezes é figurativa e poética.

\footnotetext{
${ }^{55}$ A questão é a seguinte: "Ce qui frappe les lecteurs des chroniques qui vous sont consacrés, c'est de trouver souvent votre nom associé à celui de Jean-Paul Sartre, comme si vous étiez un disciple du philosophe existencialiste. Or L'Étranger est bien loin des contes sartriens; de meme le Mythe de Sisyphe où vous critiquez..."

${ }^{56}$ En verité très peu de gens savent exactement ce qu'est l'existentialisme. Ainsi s'expliquent bien de choses. Tout ce que je peut dire pour ma part, c'est que : Je ne suis pas un philosophe. Je ne crois pas assez à la raison pour croire à un système. Ce qui m'intéresse, c'est de savoir comment il faut se conduire. Et plus précisément comment on peut se conduire quand on ne croit ni en Dieu ni en la raison. (2000, p. 1428 - Entrevista na Servir, 20 de dezembro de 1945.)

57“Les pages qui suivent traitent d'une sensibilité absurde [...] et non d'une philosophie aburde.” (MS, 2008, p.16)
} 
Le Mythe de Sisyphe se constrói, assim, no equilíbrio entre a evidência e o lirismo que nos permite aceder ao mesmo tempo à emoção e à clareza (MS, 2008, p. 18). Esse equilíbrio é encontrado principalmente no uso que Camus faz do mito de Sísifo. ${ }^{58}$

Para o escritor, o mito é precisamente o ponto de encontro entre pensamento e escrita

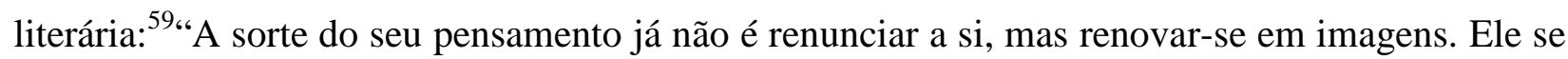
representa - em mitos, sem dúvida -, mas mitos sem outra profundidade senão a dor humana e, como esta, inesgotável." (MS, 2008, p. 133). ${ }^{60}$

Sísifo se torna uma imagem do absurdo apresentado no ensaio: o trabalho inútil e sem sentido, a presença da morte, o amor pela vida, a recusa à esperança, a tragicidade, a alegria, a lucidez. Para Lévi-Valensi, Sísifo enquanto uma imagem do absurdo é exatamente o ponto de encontro e de conciliação entre ensaio e narrativa (2006, p. 388). ${ }^{61}$

Assim, não podemos afirmar que Camus não faz filosofia, mas somente que ele o faz a partir de uma visão particular, a partir da qual "só se pensa por imagens. Se você quer ser filósofo, escreva romances" (C I, 1962, p. 23).

É assim que Sísifo se torna um personagem, o herói absurdo por excelência. Como não ler a história de Sísifo recontada por Camus e não pensar em Meursault e suas núpcias com a natureza mediterrânea e em seguida em seu exílio na prisão? Como não pensar em Meursault encarando o seu castigo, consciente de sua morte e, no entanto, feliz?

Compreendemos que, para Camus, a filosofia pode e deve se expressar através de imagens: que lugar melhor para que isso aconteça senão o romance?

Mais justement le choix qu'ils ont fait d'écrire en images plutôt qu'en raisonnements est révélateur d'une certaine pensée qui leur est commune,

\footnotetext{
${ }^{58}$ Para um aprofundamento na questão recomendamos o artigo "Albert Camus e a busca dos clássicos", de Nilson Adauto Guimarães da Silva.

${ }^{59}$ No prefácio a L'Envers et L'Endroit, Camus afirmou que se esforçava em edificar uma linguagem e fazer viver mitos (EE, 2007, p. 31), ou então que não se definia como um filósofo, mas como um artista que cria mitos na medida de sua paixão e de sua angústia (C II, 1965, p. 325).

${ }^{60}$ “Le sort de sa pensée n'est plus de se renoncer mais de rebondir em images. Elle se joue - dans de mythes sans doute - mais des mythes sans autre profondeur que celle de la douleur humaine [...]" (MS, 2008, p. 158)

${ }^{61}$ A esse respeito conferir a interessante análise que a crítica faz de "Entre oui et non", considerando a imagem como a conciliação entre as passagens alternadas de narrativa e reflexão nesse texto.
} 
persuadée de l'inutilité de tout principe d'explication et convaincue du message enseignant de l'apparence sensible. (MS, 2008, p. 138) ${ }^{62}$

É assim que ele concebe os grandes romancistas, como romancistas filósofos, ${ }^{63}$ como "pensadores lúcidos” (MS, 2008, p. 156).

\subsection{Pensamento e imagens: o romance}

Retomando os ensaios mais literários de Camus podemos afirmar que neles o escritor transita do concreto ao abstrato, da narrativa à meditação. A esse respeito, Quilliot destaca que a maior parte das reflexões que ampliam as anedotas não nasceu de uma primeira escritura: "Sem dúvida, em parte elas nasceram do desejo de dar uma unidade profunda a um conjunto de textos que podiam, à primeira vista, parecer desconexos." ${ }^{64}$

Essa unidade profunda para os textos narrativos foi algo sempre tencionado por Camus; para ele "uma obra durável não pode prescindir de um pensamento profundo." (E, 2000,p. 1417). Em 1938, o escritor aprofunda essa reflexão, escrevendo a respeito de La Nausée, de Sartre:

Um romance nunca passa de uma filosofia posta em imagens. Em um bom romance, toda a filosofia passou pelas imagens. Mas basta que ela ultrapasse as personagens e a ação, que apareça como uma etiqueta ${ }^{65}$ sobre a obra, para que a intriga perca sua autenticidade e o romance sua vida. Entretanto, uma obra duradoura não pode deixar de lado o pensamento profundo. (IC, 2002, p. 133)

\footnotetext{
62،"Mas, justamente, a opção que fizeram de escrever com imagens mais que com raciocínios revela um certo pensamento que lhes é comum, persuadido da inutilidade de todo princípio de explicação e convencido da mensagem instrutiva de aparência sensível.” (MS, 2008, p. 116)

${ }^{63}$ Esses romancistas se opõem aos escritores de tese: "Le roman à thèse, l'oeuvre qui prouve, la plus haïssable de toutes, est celle qui le plus souvent s'inspire d'une pensée satisfaite. La vérité qu'on croît détenir, on la démontre." (MS, 2008, p. 156).

${ }^{64}$ Sans doute même, pour partie, sont-elles nées du désir de donner une unité profonde à un ensemble de textes qui pouvaient, à première vue, sembler disparates [...]" (QUILLIOT, 2000, p. 1179)

${ }^{65}$ Muito provavelmente Camus está dialogando com a afirmação de Proust em Le Temps Retrouvé: "Une œuvre où il y a des théories est comme un objet sur lequel on laisse la marque du prix." (PROUST, 1989, p. 461) Sobre a relação entre teoria e romance na obra de Proust, conferir a abordagem de Vincent Descombres em Proust: Philosophie du roman Paris: Éditions du Minuit, 1987.
} 
Aqui, Camus identifica o pensamento subjacente na obra de Sartre, mas critica a forma como esse aparece. ${ }^{66}$ Em sua opinião, o equilíbrio é rompido: embora a reflexão filosófica e a história em si sejam convincentes, reunidas elas não se tornam uma obra de arte. Esse fato impede a adesão do leitor e Camus atribui isso ao desequilíbrio "tão sensível entre o pensamento da obra e as imagens em que ele aparece." (IC, 2002, p. 135).

Através dessa análise é possível compreender o motivo pelo qual, na primeira parte de L'Étranger, Meursault não tem consciência da suposta comunhão que estabelece com o mundo e nem discorre sobre ela, ele apenas a experimenta. Pelo mesmo motivo, a palavra "absurdo" aparece apenas uma vez no texto de L'Étranger e seu personagem não tem a revelação do absurdo tal como descrita em Le Mythe de Sisyphe. Sua constatação do absurdo não dá lugar a nenhuma interpretação metafísica ou intelectual. Em Meursault o "porquê", 67 tal como descrito no ensaio, nunca se levanta. Esse fato nos faz pensar que Camus poderia ter optado por outro caminho em sua narrativa, podendo ter criado um personagem que levasse essa vida mecânica e que um dia tomasse consciência da absurdidade de seus atos. Ou, ainda, que refletisse sobre o absurdo, mas, como escreve Barthes, Meursault não é ator nem moralista: ele não discorre sobre o que faz (2004, p. 95). Ao contrário, o autor nos coloca sem mediação em contato com o sentimento do absurdo expressado através dos atos de Meursault: gestos desprovidos de razões, de álibis, de tal modo que a própria brevidade do ato, sua opacidade, é o que mostra a solidão e a estranheza de Meursault (2004, p. 95).

Concluímos que, para Camus, a concepção de literatura não pode deixar de passar por uma relação com a filosofia, porém não se trata apenas de ilustrar conceitos filosóficos. Qual seria, então, o papel da filosofia em um texto literário? Camus responde que:

Pour que soit possible une oeuvre absurde, il faut que la pensée sous sa forme la plus lucide y soit mêlée. Mais il faut en même temps qu'elle n'y paraisse point sinon comme l'inteligence qui ordonne. Ce paradoxe s'explique selon l'absurde.

\footnotetext{
${ }^{66}$ Nesse trabalho não é nosso objetivo analisar a relação entre filosofia e literatura em Sartre, mas somente discuti-la na medida em que serviu para a reflexão de Camus. Para tanto recomendamos o livro Sartre e a literatura engajada, de Thana Mara de Souza, particularmente o capítulo "A especificade da prosa".

67"Il arrive que les décors s'écroulent. Lever, tramway, quatre heures de bureauou d'usine, repas, tramway, quatre heures de travail, repas, sommeil et lundi mardi mercredi jeudi vendredi et samedi sur le même rythme, cette route se suit aisément la plupart du temps. Un jour, seulement, le "pourquoi" s'élève et tout commence dans cette lassitude teintée d'étonnement."(MS, 2008, p. 29)
} 
L'oeuvre d'art naît du renoncement de l'intelligence à raisonner le concret. (MS, 2008, p. 134$)^{68}$

Aqui a "inteligência" contém a mesma ideia do pensamento que subjaz à obra. E da mesma forma, ela não pode aparecer sobre a obra, a não ser como aquilo que organiza. Em seu ensaio "A inteligência e o cadafalso", contemporâneo de Le Mythe, Camus coloca essa concepção em prática para analisar o romance de Mme. de Lafayette:

Encontramos assim, no coração de nossas grandes obras romanescas, uma certa concepção do homem que a inteligência se esforça por colocar em evidência em meio a um pequeno número de situações. Isso certamente poderá ser dito de qualquer bom romance se for verdade que o romance faz da inteligência seu universo, assim como o drama faz da ação o seu. (IC, 1998, p. 19)

Nesse caso, a inteligência serve para colocar em evidência uma concepção sobre o homem através das ações da narrativa. Ao analisar a escrita de Mme. de Lafayette, ele entende que sua concepção de amor aparece, por exemplo, na construção do personagem e na própria linguagem da qual ela se utiliza.

Retomando a relação entre L'Étranger e Le Mythe, podemos afirmar que o parentesco temático entre as obras é evidente, masa narrativa não pode ser simplesmente considerada como uma ilustração das teorias sustentadas no ensaio. Como ressalta Lévi-Valensi (E, 2000, p. XXXII), L'Étranger "é demasiadamente inventivo e rico para ser reduzido a uma "ilustração" por mais "concentrada" que seja ela - das teorias; ele tem sua estrutura autônoma, sua existência própria, ele representa o absurdo por meio de uma abordagem bem diferente daquela do Mythe.". ${ }^{69} \mathrm{O}$ absurdo não é uma etiqueta, mas uma inteligência que organiza, e por esse motivo ele está intricado no processo de criação da narrativa.

\footnotetext{
68 "Para tornar possível uma obra absurda, é preciso que o pensamento, na sua forma mais lúcida, esteja inserido nela. Mas ao mesmo tempo. É preciso que só apareça como inteligência ordenadora. Este paradoxo se explica de acordo com o absurdo. A obra de arte nasce da renúncia da inteligência a raciocinar o concreto.” (MS, 2008, p. 113)

69،"est trop inventif et trop riche pour être réduit à une « illustration » - aussi «concentrée » soit-elle - des théories ; il a sa structure autonome, son existence propre, il represente l'absurde par une approche bien différente de celle du Mythe." (E, 2000, p. XXXII)
} 


\subsection{Onde um começa e o outro termina?}

Retomando o texto de Sartre, podemos observar que a leitura que ele faz de L'Étranger é sempre pautada por sua relação com Le Mythe de Sisyphe. Para ele, o fato de que as duas obras façam parte do mesmo ciclo ajudaria na recepção por parte do leitor:

O Estrangeiro, lançado primeiro, nos mergulha sem comentários no "clima" do absurdo; o ensaio vem em seguida para iluminar a paisagem. Ora, o absurdo é o divórcio, o deslocamento. $O$ Estrangeiro seria então o romance do deslocamento, do divórcio, do desterro. (SARTRE, 2005, p. 124)

Embora já tenhamos abordado a posição sartriana, ela é original na medida em que considera a recepção do romance. Na citação acima, particularmente na segunda parte, Sartre é também original em apontar para o processo de criação: se o absurdo é essencialmente um divórcio, logo, L'Étranger será a narrativa do divórcio. E vamos mais longe: se a noção do absurdo não se separa da noção de núpcias, podemos dizer que L'Étranger é a narrativa do avesso e do direito.

Mas como isso se dá no processo de criação?

Em uma das mais belas páginas dedicadas a L'Étranger, Barthes escreve que o estilo do livro tem algo de marinho: "a cor vem do reflexo do fundo sobre a superfície, que é por onde precisamos passear, não pelo céu ou pelos abismos" (2004, p. 42). Para o crítico, o estilo de L'Étranger se submete à presença submarina das areias imóveis de Le Mythe de Sisyphe, sendo, portanto, "um exemplo notável de bizarras incidências do fundo sobre a forma." (2004, p. 43).

Assim, essa relação seria melhor pensada como uma relação entre um fundo e uma forma, entendendo aqui o fundo como a filosofia subjacente. Assim, as colocações de Barthes nos propõem uma saída para pensar a relação entre filosofia e literatura no processo de criação de L'Étranger.

Para exemplificar esse processo escolhemos uma pequena história anotada nos Carnets:

A mulher que vive com seu marido sem nada entender. Um dia ele fala na rádio. Colocam-na atrás de um vidro e ela pode vê-lo sem ouvi-lo. Ele faz somente gestos [...] Pela primeira vez, ela pode vê-lo em seu corpo [...] como um 
marionete que ele é. Ela deixa-o. "É esta marionete que monta no meu ventre todas as noites." 70

Trata-se de uma narrativa de uma mulher que vive com seu marido, sem refletir sobre isso. Um dia, sua desumanidade se revela a ela através da separação entre seus gestos e sua fala. Essa mesma ideia é recuperada em L'Envers et L'Endroit, mas agora, sem a mediação da narrativa, a revelação aparece através da imagem de uma cortina que se levanta: "E eis que a cortina dos hábitos, a trama confortável dos gestos e das palavras em que o coração se acalma, se levanta lentamente e descobre, enfim, a face lívida da inquietação.” (EE, 19-?, p. 77). ${ }^{71}$

Em Le Mythe de Sisyphe, essa mesma ideia será recuperada como a definição do sentimento do absurdo:

Les hommes aussi sécrètent de l'inhumain. Dans certaines heures de lucidité, l'aspect mécanique de leurs gestes, leur pantomime privée de sens rend stupide tout ce qui les entoure. Un homme parle au téléphone derrière une cloison vitrée ; on ne l'entend pas, mais on voit sa mimique sans portée : on se demande pourquoi il vit. (MS, 2008, p. 31)

Temos aqui, mais uma vez, separação entre os gestos e a fala, o mal-estar (“a inquietação") nasce do fato de que os atos dos homens ficam privados de significação, de intencionalidade.

Em L'Étranger não reencontraremos nenhuma dessas imagens (da rádio, da cortina que se abre, da cabine telefônica), mas essa ideia estará presente de uma maneira diferente: para Sartre (2005) essa divisória envidraçada é própria consciência de Meursault, ela deixa transparecer os atos, mas é opaca às significações, aos sentimentos. Esse fato causa um estranhamento, uma inquietude tanto no leitor quanto nos outros personagens. Ao observarmos essa mímica sem

\footnotetext{
${ }^{70} \mathrm{La}$ femme qui vit avec son mari sans rien comprendre. Il parle un jour à la radio. On la met derrière une glace et elle peut le voir sans l'entendre. Il fait seulement des gestes [...] Pour la première fois, elle le voit dans son corps [...] comme un pantin qu'il est. Elle le quitte «C'est cette marionette qui monte sur mon ventre tous les soirs. » (C I, 1962, p. 156)

${ }^{71}$ “Et voici que le rideau des habitudes, le tissage confortable des gestes et des paroles où le cœur s'assoupit, se relève lentement et dévoile enfin la face blême de l'inquiétude." (EE, 2007, p. 82)

${ }^{72}$ Os homens também segredam desumanidade. Em certas horas de lucidez, o aspecto mecânico de seus gestos, sua pantomima desprovida de sentido torna estúpido tudo o que os rodeia. Um homem fala ao telefone atrás de uma divisória de vidro; não se ouve o que diz, mas vemos sua mímica sem sentido: perguntamo-nos por que ele vive. (MS, 2008, p. 29)
} 
significação até mesmo nosso processo de leitura é questionado. ${ }^{73}$ Concluímos que a ideia está presente aqui, mas de uma forma subjacente, não como um episódio da narrativa, mas em sua estrutura.

Barthes, ao comentar o estilo de L'Étranger, relaciona-o ao absurdo: "Naturalmente, para esse tema novo era preciso uma narrativa nova." (2004, p. 95). O absurdo demanda assim uma busca da forma, um trabalho com a linguagem.

Camus também esposa essa ideia ao estabelecer a importância do estilo para a obra: "Mas eu não imagino literatura sem estilo. Eu só conheço uma revolução na arte, e ela é a de todos os tempos, a exata apropriação da forma e do fundo, da linguagem e do assunto.”(E, 2000, p. 1427). ${ }^{74}$ Assim, para Camus, a reflexão filosófica é fundamental para o processo de criação da obra literária. Ao refletir sobre outros autores, ele escreve:

Nas questões que nossos grandes romancistas se colocaram não interessava a forma pela forma, mas somente a relação precisa que eles queriam introduzir entre seu tom e seu pensamento. A meio caminho entre a monotonia e a loquacidade, eles tinham que encontrar uma linguagem para sua obstinação. (IC, p. 16)

Ou seja, no romance deve haver um equilíbrio entre o estilo e o pensamento, entre a linguagem e a obstinação do autor. No entanto, o fundo e a forma não podem ser pensados como uma dicotomia: eles não são entidades estanques, pois a forma é a própria essência do fundo. Como explica Starobinski, a forma não é a roupagem exterior do fundo, ela não é a aparência sedutora por trás da qual se esconde uma realidade preciosa: a escritura não é o truque duvidoso dessa experiência interior, ela é a própria experiência. (1989, p.18)

Da mesma forma, o limite entre a filosofia e a ficção na obra de Camus é muito difícil de ser estabelecido: não podemos pensar sua ficção sem uma filosofia subjacente e, ao mesmo tempo, somente podemos pensar sua filosofia como aquela que se afasta de uma sistematização e trabalha com imagens. Assim como nos ensaios, a passagem da narrativa para a reflexão se fazia no interior do texto ${ }^{75}$, aqui também elas não podem se separar. Assim, literatura e filosofia são

\footnotetext{
${ }_{73}^{73}$ Cf. "Senhores Jurados: os leitores". Revista Criação \& Crítica,n. 1, 2008.

74،"Mais je n'imagine pas de littérature sans style. Je ne connais qu'une révolution en art, elle est de tous les temps, c'est l'exacte appropriation de la forme et du fond, du langage et du sujet."

${ }^{75}$ Para explicar as relações entre a reflexão filosófica e a literária nos escritos sartrianos, Leopoldo e Silva apresenta-nos a ideia de vizinhanças comunicantes: "A relação de uma e outra se daria por uma espécie de comunicação que, à falta de outro termo, chamaríamos de passagem interna, querendo significar com isso que a
} 
inseparáveis, elas formam o avesso e o direito da escritura camusiana, e essa intrincação significa a presença do avesso no direito e do direito no avesso.

vizinhança entre filosofia e literatura é tal que não se precisaria, nem se poderia, sair de uma para entrar na outra, configurando assim dois espaços contíguos, mas apenas indiretamente incomunicáveis, ou seja, em que a passagem de um a outro se daria pela mediação da exterioridade.” (2004, p.13) 


\section{A MORTE PARA TODOS, PARA CADA UM A SUA MORTE}

\section{Apresentação}

Em 1961, Jean de Starobinski publicava seu livro sobre a obra de Rousseau, onde se revelavam para ele dois temas fundamentais: a transparência e o obstáculo. Temas provenientes da obra, mas que tornariam inútil qualquer trabalho de pesquisa que se propusesse a encontrá-los explicitamente no texto. Eles nascem antes de um olhar particular sobre o texto, de uma leitura do crítico. Ao olhar para a obra de Rousseau, Starobinski não pode separá-la do mundo ao qual ela se opõe: Rousseau deseja a transparência do coração; para chegar a ela, afasta-se da sociedade e, em sua solidão, encontra o espaço sem obstáculos da escrita íntima.

Ao olharmos para L'Étranger, encontramos o tema do avesso e do direito, ligado primordialmente ao percurso filosófico de Camus. Da mesma forma seria inútil procurá-lo na narrativa: as núpcias e o absurdo não estão de forma alguma lá explicitados. No entanto, na superfície do texto, um tema se repete e ecoa na memória do leitor: a morte, da mãe, do árabe e de Meursault. Esse eco pode ser sentido também entre L'Envers et L'Endroit e L'Étranger: o último ensaio do livro termina exatamente onde a narrativa começa: em um cemitério. A morte é assim o primeiro tema que liga os dois textos. Ela é também uma constante nos escritos de juventude, assim como em La Mort Heureuse, narrativa intermediária entre os ensaios e L'Étranger.

À primeira vista, a morte parece ser um tema que se liga somente ao absurdo: todo sentido da vida é negado pela absurdidade de uma morte possível. No entanto, esse tema se liga também às núpcias: a morte é uma realidade que impede o homem de desfrutar do mundo, quanto mais exaltante é a vida, mais absurda é a ideia de perdê-la. Portanto, é o tema da morte que filosoficamente conduz ao absurdo: o homem percebe o quanto está separado do mundo, que 
permanece, enquanto os homens sofrem e se vão. A morte, no entanto, não é um tema lúgubre, mas trágico. Essa tragicidade, porém, não aparece em seus textos através de uma expressão de amargura e pessimismo diante da existência. ${ }^{76}$ Esse é o erro de uma certa literatura que acredita que a vida é trágica porque é miserável, quando a questão é exatamente oposta: a vida pode ser emocionante e magnífica, eis a sua tragédia. ${ }^{77}$ Esse foi exatamente o erro de muitos críticos ao lerem os ensaios de L'Envers et L'Endroit, pois, neles, a ênfase à ideia de morte é sobretudo um convite à vida. Em carta a Jean de Maisonseul, o escritor responde a essas críticas:

Si je n'ai pas dit tout le goût que je trouve à la vie, toute l'envie que j'ai de mordre à pleine chair, si je n'ai pas dit que la mort même et la douleur ne faisaient qu'exaspérer en moi cette ambition de vivre, alors je n'ai rien dit. (OC I, 2006, p. 97 $)^{78}$

Para Camus, a certeza da morte, "esse desespero secreto", está estritamente ligada "a este amor devorante da vida" (EE, 2007, p. 119). A revelação do absurdo, portanto, não deve conduzir ao suicídio, é preciso antes viver e desfrutar desse mundo. Em Le Mythe de Sisyphe, lemos que ninguém descobre o absurdo sem ficar tentado a escrever um manual de felicidade. Felicidade e Absurdo são filhos da mesma terra, como o avesso e o direito, eles são inseparáveis (MS, 2008, p. 167). A grande tragicidade do mito de Sísifo está no fato de descobrir-se mortal e amar a vida.

A proposta desse capítulo é analisar como o tema da morte se liga à reflexão filosófica das núpcias e do absurdo tornando-se seu tema central, unindo tematicamente L'Étranger e os textos anteriores.

\footnotetext{
${ }^{76}$ É nesse sentido que podemos compreender a nota acerca de Nietzsche nos Carnets: "L'artiste tragique n'est pas un pessimiste. Il dit oui à tout ce qui est problématique et terrible. (Crépuscole des Idoles)” (C I, 1962, p. 174).

77 "Sem a beleza, o amor ou o perigo, seria quase fácil viver. E o herói de Sartre talvez não tenha entendido o verdadeiro sentido de sua angústia quando insiste no que lhe é repugnante no homem, ao invés de fundar em algumas de suas grandezas os motives para se desesperar." (IC, 1998, p. 135-136)

78 "Se eu ainda não falei de todo o gosto que eu encontro na vida, todo o desejo que eu tenho de mordê-la, se eu ainda não falei que a morte e a dor não fazem mais que exasperar em mim essa ambição de viver, então eu não disse nada". (tradução nossa)
} 


\section{Hoje mamãe morreu...}

\subsection{Os ritos da morte}

L'Étranger se abre com a notícia da morte da mãe de Meursault, seu velório no asilo e seu enterro no cemitério em Marengo. Na segunda parte da narrativa esse fato não cessa de ser recuperado pela acusação de Meursault no tribunal. O tema do enterro ligado ao sentimento de luto e a comédia social interpretada nesse ritual é central para a escritura de L'Étranger, uma vez que estabelece um paralelismo entre as duas partes da narrativa.

Esse tema aparece pela primeira vez em um texto publicado em L'Envers et L'Endroit, no final da terceira parte do ensaio "L'Ironie"; trata-se do neto que não se ressente com a morte da rude avó: "Só no dia do enterro, por causa da explosão geral de lágrimas, chorou, mas com o temor de não ser sincero e de mentir diante da morte." ${ }^{79}$ Nessa pequena frase, o tema aparece de forma concentrada: o enterro, o questionamento sobre o enlutamento e o fingimento diante da morte.

O tema do enterro e do luto, no entanto, já havia aparecido em diversos textos datados de 1933; entre eles citamos "Devant la morte" e "Perte de l'être aimé" (EJ, 1973). O primeiro contém o embrião de uma forma romanesca, enquanto o segundo se expressa sob a forma de reflexões de ordem moral ou filosófica, mas ambos têm como tema o desaparecimento do ser amado e as reações a essa perda.

O narrador de "Devant la morte" se coloca a questão de como se portar durante o funeral, chegando à conclusão de que: "seu súbito desespero parecia-lhe uma comédia [...] É muito difícil dividir o que é mentira do que é verdade em cada um de nossos atos." 80 Assim, o principal assunto do texto é a comédia interpretada diante da morte, principalmente a comédia social: aquela que revela o contraste entre a atitude que esperamos daquele que vela a morta e sua reação. O narrador continua:

\footnotetext{
${ }^{79}$ (EE, 19-?, p. 46) "Le jour de l'enterrement seulement, à cause de l'explosion générale des larmes, il pleura, mais avec la crainte de ne pas être sincere et de mentir devant la mort." (EE, 2007, p. 51)

${ }^{80}$ (tradução nossa) "Il fallait bien l'avouer, son subit désespoir lui semblait maintenant une comédie. [...] C'est qu'il est très difficile de faire part de ce qui est démenti et de ce qui est vrai dans chacun de nos actes.” (EJ, 1973, p. 228)
} 
Maintenant que tout était achevé, il n'y avait plus qu'à attendre. L'inhumation aurait lieu demain. [...] En fait, il ne se sentait pas du tout disposé à prévenir la famille. On le regarderait avec curiosité. Il jouerait malgré lui la comédie. Il lui faudrait hocher la tête doulouresement et chasser d'un geste machinal le cruel souvenir. Il lui faudrait être «un homme fini ». Et il sentait fort bien qu'il ne l'était pas du tout. (EJ, 1973, p. 229) ${ }^{81}$

Nessa passagem, o narrador reflete sobre os gestos que é preciso fazer diante da morte, os gestos que todos esperam. Mas ele confronta essa "obrigação" aos sentimentos do personagem que não se sentia de modo algum enlutado.

Na escritura de L'Étranger o tema conserva os mesmo contornos, mas adquire outros desdobramentos, retomando a ideia de um processo em espiral. Em primeiro lugar, podemos afirmar que o sentimento de enlutamento está também ausente em Meursault. Por exemplo, o personagem pede dois dias de folga ao patrão para enterrar a mãe e este tampouco lhe dirige as condolências. Meursault nota o fato e conclui que é porque ele mesmo não se mostrou enlutado naquela hora e o fato é que não se mostrará em nenhum momento (Et, 1996, p. 9). ${ }^{82}$ Essa é justamente a primeira vez em que ele nota a distância entre o que sente e o que as pessoas esperam dele. Mas essa percepção não vem acompanhada de uma reflexão, como faz o narrador de "Devant la morte". A reflexão acerca do comportamento diante da morte se dará através de outros personagens, como a mulher do zelador, que pede ao marido que não fale certas coisas ao filho da falecida. ${ }^{83}$ Meursault, ao contrário, acha verdadeiro e interessante o que o homem lhe conta (Et, 1996, p. 13).

Há ainda outros momentos na narrativa nos quais Meursault percebe a fissura que existe entre seu comportamento e aquilo que a sociedade esperaria de um filho. Por exemplo, o porteiro

\footnotetext{
81 “Agora que tudo estava acabado, não havia mais nada a esperar, o funeral seria amanhã. [...] Na verdade, ele não se sentia muito disposto a avisar a família. Observariam-no com curiosidade. Ele interpretaria a comédia contra sua vontade. Seria preciso que ele balançasse a cabeça dolorosamente e rejeitasse com um gesto mecânico a lembrança cruel. Seria preciso que ele fosse 'um homem acabado'. E ele sentia perfeitamente que não era." (tradução nossa)

${ }^{82}$ Podemos observar essa recusa ao luto também nesta passagem: "Quand nous nous sommes rhabillés, elle a eu l'air très surprise de me voir avec une cravate noire et elle m'a demandé si j'étais en deuil. Je lui ai dit que maman était morte. Comme elle voulait savoir depuis quand, j'ai répondu: «Depuis hier.» Elle a eu un petit recul, mais n'a fait aucune remarque. J'ai eu envie de lui dire que ce n'était pas de ma faute, mais je me suis arrêté parce que j'ai pensé que je l'avais déjà dit à mon patron. Cela ne signifiait rien. De toute façon on est toujours un peu fautif." (Et, 1996, p. 24).

83 “À Paris, on reste avec le mort trois, quatre jours quelquefois. Ici on n’a pas le temps, on ne s'est pas fait à lídée que déjà il faut courir derrière le corbillard.” (Et, 1996, p. 13)
} 
deseja desparafusar o caixão para que Meursault veja sua mãe, mas ele o detém. O homem questiona-o e ele não sabe responder por que não desejava ver o corpo da mãe: "[...] eu estava embaraçado porque sentia que não devia ter dito isso". ${ }^{84}$ Em outro momento, o personagem reflete sobre como deveria se portar diante da mãe morta quando sente vontade de fumar: "Mas hesitei, porque não sabia se o podia fazer diante da minha mãe. Pensei, e concluí que isso não tinha importância nenhuma.". ${ }^{85}$

O leitor também percebe essa fissura ao ler o incipit da narrativa: a ausência de sentimentos ao relatar a morte da mãe soa quase a indiferença. ${ }^{86}$ No velório, o personagem parece não se sentir de modo algum triste, ele narra somente seu cansaço e o mal-estar que certas situações lhe causam. Mais que isso, notamos que Meursault também não chora a morte da mãe. Os dois personagens que o fazem são apresentados por ele em todo o seu exagero e seu ridículo. A senhora amiga de sua mãe o incomoda: "Chorava dando pequenos gritos, regularmente: parecia-me que nunca mais pararia de chorar.". ${ }^{87} \mathrm{E}$ as lágrimas no rosto de Perez não marcam mais que sua deformidade: "Grossas lágrimas de enervamento e de tristeza corriam-lhe pela cara abaixo. Mas, por causa das rugas, não caíam. Dividiam-se, juntavam-se e formavam uma máscara de água nessa cara arruinada." ${ }^{88}$.

Assim, ao contrário de demonstrar seu luto, Meursault parece demonstrar uma verdadeira indiferença em relação à morte da mãe. E é com essa indiferença que, no final do primeiro capítulo, ele resume o enterro da mãe a algumas imagens e relata a sua alegria ao saber que iria chegar à sua casa e dormir durante 12 horas. ${ }^{89}$

${ }^{84}$ (Et, 1979, p. 159) "Il s'est interrompu et j'étais gêné parce que je sentais que je n'aurais pas dû dire cela.” (Et, 1996, p. 12)

${ }_{85}$ (Et, 1979, p. 162) "Mais j'ai hésité parce que je ne savais pas si je pouvais le faire devant maman. J'ai réfléchi, cela n'avait aucune importance." (Et, 1996, p. 14)

${ }^{86} \mathrm{O}$ incipit inicia-se por uma imprecisão quanto à morte da mãe: ele afirma hoje, ou talvez ontem, mas isso não tem importância alguma para ele. A indiferença relacionada quanto à imprecisão ou à aparente indecisão diante de algumas situações reaparecerá na narrativa através da expressão "ça m’est égal": tanto faz ser ou não amigo de Raymond, ir ou não para Paris, casar-se ou não com Marie.

${ }^{87}$ (Et, 1979, p. 164) "Elle pleurait à petits cris, régulièrement: Il me semblait qu'elle ne s'arrêterrait jamais." (Et, 1996, p. 15)

${ }^{88}$ (Et, 1979, p. 172) "Des grosses larmes d'énervement et de peine ruisselaient sur ses joues. Mais à cause des rides, elles n'écoulaient pas. Elles s'étalaient, se rejoignaient et formaient un vernis gros sur ce visage détruit." (Et, 1996, p. 22)

${ }^{89}$ Essa é a mesma reação que Mersault de La Mort Heureuse tem depois de assassinar Zagreus, o que nos lembra a acusação no tribunal de que Meursault matou a mãe com um coração criminoso. 
Em todos os textos que citamos, percebemos ainda outra relação com a morte da mãe em L'Étranger: todas as cenas de luto se relacionam a uma personagem feminina - em "Devant la morte" a falecida é a amada, no texto de "L’Ironie" essa mulher passa a ser da família, é a avó. A morte da mãe, porém, aparecerá somente em La Mort Heureuse.

Nessa narrativa inacabada, o personagem também se comporta de maneira indiferente à morte da mãe. No trecho a seguir, o narrador confronta a reação dos outros e a reação do próprio personagem:

On les suppliait de le protéger et de se consacrer à lui. Lui, cependant, s'habilla du mieux qu'il put et, le chapeau à la main, contempla les préparatifs. Il suivit le convoi, assista au service religieux, jeta sa poignée de terre et serra des mains. Une fois seulement, il s'étonna et exprima son mécontentement de ce qu'il y eût si peu de voitures pour les invités. Ce fut tout. Le lendemain on put voir à la une des fenêtres de l'appartement un écriteau : «À louer. » (OC I, 2006, p. 1112) ${ }^{90}$

O narrador nos relata que Mersault cumpre apenas o ritual que a morte demanda, e expressa os seus sentimentos apenas uma vez, mas em relação ao seu descontentamento em relação a um detalhe, nada mais. A reflexão sobre o fingimento diante da morte está ausente nessa passagem, mas a maneira como o narrador relata o comportamento de Mersault ("Foi só”) marca a sua indiferença.

Em La Mort Heureuse, porém, a morte da mãe é apenas uma passagem na vida desse personagem. O episódio mais importante na narrativa é o assassinato, colocado no primeiro capítulo. Em L'Étranger, por sua vez,o episódio da morte da mãe será recuperado e expandido passando de um simples relato de duas páginas a todo o primeiro capítulo (o assassinato que o personagem comete passará a ocupar o último capítulo da primeira parte). Essa mudança nos coloca alguns questionamentos: se Meursault é mesmo tão indiferente à morte da mãe, por que ele inicia sua narração exatamente pela sua morte?

Essa indiferença manifesta-se, como vimos, através de uma ausência do luto. Como em Mersault de La Mort Heureuse, a reflexão sobre o enlutamento também não se dá para Meursault.

\footnotetext{
${ }^{90}$ Suplicaram-lhe que o protegessem e cuidassem dele. Patrice, no entanto, vestiu-se da melhor forma que pôde e, de chapéu na mão, contemplou os preparativos. Acompanhou o cortejo, assistiu ao ofício religioso, jogou seu punhado de terra e apertou a mão de todos. Apenas uma vez espantou-se e manifestou seu descontentamento com o fato de haver tão poucos carros para os convidados. Foi só. No dia seguinte, viu-se numa das janelas do apartamento o cartaz: "Aluga-se". (MF, 1997, p. 28)
} 
Chama a atenção, porém, que esse tema está ausente no personagem, mas não ausente na narrativa, fazendo-se presente através do julgamento do personagem.

O primeiro dado que encontramos a esse respeito é a reação do advogado de defesa à investigação feita em Marengo: os investigadores souberam que no dia do enterro da mãe Meursault havia dado provas de insensibilidade. O advogado lhe pergunta se nesse dia ele realmente tinha demonstrado algum sofrimento, mas ele responde que nunca se questionava a esse respeito. É claro que gostava de sua mãe, como todo mundo, mas isso não queria dizer nada: “Todos os seres saudáveis tinham, em certas ocasiões, desejado mais ou menos, a morte das pessoas que amavam.". 91 O advogado se preocupa com a resposta, pois sabe que esse será um grande argumento para a acusação. Mas Meursault ressalta que essa história não tinha nenhuma relação com o crime que ele havia cometido. $\mathrm{O}$ advogado apenas responde que se via bem que ele não conhecia a justiça de perto. Começa a se delinear aqui a relação entre a morte da mãe e a morte do árabe.

No julgamento, o depoimento do diretor do asilo é o primeiro a colocar em questão o enterro da mãe:

Il a répondu qu'il avait été surpris de mon calme le jour de l'enterrement. On lui a demandé ce qu'il entendait par calme. [...] il a dit que je n'avais pas voulu voir maman, je n'avais pas pleuré une seule fois et j'étais parti aussitôt après l'enterrement sans me recueillir sur sa tombe. Une chose encore l'avait surpris: un employé des pompes funèbres lui avait dit que je ne savais pas l'âge de maman. (Et, 1996, p. 89) ${ }^{92}$

O diretor enumera todos os fatos que considera ser um comportamento inadequado diante da morte de uma mãe. Em seguida, vem o depoimento do zelador do asilo, que recupera o fato de que Meursault havia fumado e aceitado uma xícara de café com leite diante do corpo da mãe. $\mathrm{O}$ procurador, por sua vez, complementa que um desconhecido poderia ter oferecido um cigarro, mas que ele não deveria ter aceitado fumar diante do corpo daquela que lhe deu à luz.

Observamos mais uma vez que a reflexão sobre a comédia social interpretada diante da morte aparece na distância entre as atitudes do personagem e aquilo que a sociedade espera dele.

${ }^{91}$ (Et, 1979, p. 229) "Tous les êtres sains avaient plus ou moins souhaité la mort de ceux qu'ils aimaient.” (Et, 1996, p. 67)

92،A uma outra pergunta, respondeu que a minha calma no dia do enterro o surpreendera. Perguntaram-lhe o que entendia ele por 'calma'. [...] disse que eu não quisera ver o corpo da minha mãe, que não chorara uma única vez e que partira logo a seguir ao enterro, sem permanecer sequer uns momentos no cemitério. Espantara-o uma outra coisas: um empregado da agência funerária dissera-lhe que eu não sabia a idade de minha mãe.” (Et, 1979, p. 259) 
A questão principal do julgamento, no entanto, está no fato de que ele não chorou no enterro da mãe. A reflexão sobre o fingimento diante da morte ligado à ausência do choro já está presente em "La Maison Mauresque", texto de 1993: o narrador relata que seu desejo é temer a morte de maneira simples e sem complicação, porque é o que se exige de nós - e esse sentimento pode também se expressar sem lágrimas e sem mentiras. ${ }^{93}$

O que significa mentir diante da morte? Segundo Camus, mentir não é somente afirmar o que é falso, mas também aumentar seus sentimentos. Essa atitude é resumida por Meursault: o advogado lhe pergunta se ele poderia dizer que no dia do enterro da mãe ele tinha dominado seus sentimentos naturais e por causa disso não chorou, mas ele responde: "Não, porque não é verdade." (Et, 1996, p. 67). Mas sua insensibilidade se torna também um crime: o advogado pergunta a todos se acusam o seu cliente de ter assassinado ou de lhe ter morrido a mãe (Et, 1996, p. 96). O procurador responde que era preciso ter ingenuidade para não sentir que entre as duas ordens de fatos existia uma relação patética, profunda e essencial. Meursault é, dessa forma, acusado de matar a mãe moralmente e de ter assistido a seu enterro com um coração criminoso: estruturalmente a morte da mãe liga-se à morte do árabe.

Em um texto posterior sobre L'Étranger, é possível esclarecer a questão: Meursault é condenado porque aceita morrer pela verdade: ele se recusa a jogar o jogo. ${ }^{94}$ É interessante notar o uso do verbo jouer, que significa, em francês, ao mesmo tempo jogar e interpretar. ${ }^{95} \mathrm{~A}$ afirmação do escritor contempla esses dois sentidos: Meursault recusa as regras do jogo que a sociedade impõe e se recusa a intepretar, a "mentir" diante dessa mesma sociedade: "Comédia. Simulação. É preciso ser sincero. Sincero a todo preço, mesmo contra nós", 96 lemos em um texto de juventude.

\footnotetext{
93 "Et la rage de cette défaite me faisait souhaiter enfin de passer de l'adolescent qui croit en son orgueil à l'homme arrivé, fini, mourant dans ses habitudes, me faisait souhaiter de craindre la mort sans complication et sans hantise, simplement, parce qu'on doit craindre la mort, de ne plus pleurer, non par héroïsme mais par platitude, de ne plus mentir, non par franchise mais par bêtise." (EJ, 1973, p. 215)

94 "Préface à l'édition américaine" (OC I, 2006, p. 215-216)

${ }^{95}$ O jogo é uma imagem recorrente em L'Étranger. No momento do interrogatório Meursault afirma: "J'avais déjà lu une description semblable dans les livres et tout cela m'a paru un jeu." (Et, 1996, p. 66). Da mesma forma ele conclui a história da Tchecoslováquia: "De toute façon, je trouvais que le voyageur l'avait un peu mérité et qu'il ne faut jamais jouer.” (Et, 1996, p. 80).

96 "Comédie. Simulation. Il faut être sincère. Sincère à tout prix, même contre nous." (EJ, 1973, p. 239)
} 
Se ligarmos a comédia social ao teatro, ${ }^{97}$ podemos nos lembrar que o sentimento do absurdo é descrito justamente como um divórcio entre o ator e seu cenário. Assim, podemos pensar a cena do julgamento em L'Étranger como uma cena teatral, com seu cenário, seus atores e a presença do público que reage com risos. Meursault é justamente esse ator separado de seu cenário, pois se encontra alheio a esse "espetáculo", ele desconhece ao mesmo tempo um certo número de regras dessa sociedade e os procedimentos da retórica interpretados por esses representantes do teatro social: o juiz, o procurador, o capelão.

No entanto, esse desconhecimento é somente aparente: Meursault é extremamente consciente, e é através dessa consciência que ele percebe as fissuras nesse cenário ao observar, por exemplo, o quanto seu veredicto é absurdo: "Que importava se, acusado de um crime, era executado por não ter chorado no enterro da minha mãe?". ${ }^{98}$ Esse tribunal liga a falta de comoção de Meursault diante da morte da mãe à indiferença, mas e se essa indiferença estivesse ligada a um estado de tranquilidade, de naturalidade diante da morte?

Em certo momento da narrativa vem à mente de Meursault a lembrança de Marie, de quem ele não tinha mais notícias. Ele conclui que ela poderia estar doente ou morta, e isso estaria na ordem das coisas. A partir dessa conclusão, essa lembrança se torna indiferente para ele; se estivesse morta, Maria já não mais o interessava e isso era totalmente normal, uma vez que ele compreendia que as pessoas também iam esquecê-lo depois da morte (Et, 1996, p. 115).

Se entendermos que o enterro, principalmente de natureza religiosa, é um rito de passagem, ligado principalmente a uma ideia de transcendência, podemos pensar que essa naturalidade e esse questionamento do rito estão ligados principalmente ao fato de que no pensamento camusiano a morte é uma porta fechada, ela não abre para outra vida (N, 2008, p. 27). Vemos aqui como o percurso filosófico e narrativo se ligam, no processo de elaboração, através do que chamamos no primeiro capítulo de unidade profunda entre os textos.

Mas em nossa sociedade, afirma Camus mais tarde, todo homem que não chora no enterro de sua mãe arrisca-se a ser condenado à morte.". ${ }^{99}$ A ligação dentro do romance entre a morte da mãe e a morte de Meursault, mais do que estrutural, é também simbólica: como somente

\footnotetext{
${ }^{97}$ A comédia é entendida aqui como uma peça teatral de qualquer gênero, não se restringindo àquela que causa risos no espectador, e ao mesmo tempo como um sentimento simulado, fingimento.

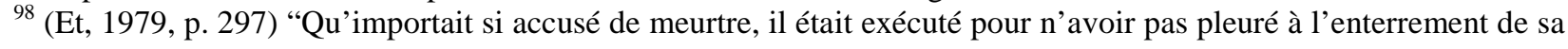
mère ?" (Et, 1996, p. 121)

99،"Dans notre société tout homme qui ne pleure pas à l'enterrement de sa mère risque d'être condamné à mort." (OC I, 2006, p. 215)
} 
podemos experimentar a morte dos outros, ela prefigura nosso destino e nos lembra que um dia também morreremos (MS, 2008, p. 32). E essa morte deve ser encarada com a mesma indiferença, com a mesma naturalidade.

\subsection{Um estranho sentimento}

A morte e a evocação da morte da mãe de Meursault permeiam toda a narrativa, no entanto, a mãe não aparece propriamente como um personagem. Esse fato nos chama a atenção, uma vez que o tema da relação entre a mãe e o filho permeia todos os primeiros escritos. Essa relação se torna ainda mais capital para a escritura de L'Étranger quando reconhecemos nos escritos anteriores o silêncio, a indiferença e o absurdo como aspectos dessa relação.

No ensaio "Entre oui et non", essa relação é descrita como fundamentalmente silenciosa: a mãe é apresentada como uma mulher doente que pensava com dificuldade, sofrendo de surdez e de uma mudez triste. $\mathrm{O}$ narrador do ensaio se lembra de chegar à sua casa e encontrar a mãe sozinha no silêncio, ficando longos minutos a olhá-la, enquanto a noite caía. Diante dessa situação, ele sentia-se estranho. Logo a avó voltaria, a luz do candeeiro se acenderia e a vida renasceria na casa. Mas, naquele momento, o silêncio marcava um compasso de espera, um instante desmedido. É nesse silêncio, contraposto à luz e aos ruídos da rua, que o menino sente amar a mãe.

O tema do silêncio já estava presente nos primeiros escritos de Camus, como deixa entrever o título do texto "Les Voix du quartier pauvre" (1933), uma tentativa de dar voz a personagens envelhecidos, pobres, solitários. ${ }^{100}$ A primeira das vozes evocadas no texto é exatamente a "da mulher que não pensava", personagem que podemos relacionar àquela descrita anteriormente. Como no ensaio, o texto inicia-se por uma longa reflexão sobre a memória e o narrador conclui que se lembrava não de uma alegria do passado, mas de um estranho sentimento do qual ele havia sofrido. Esse "estranho sentimento" nasce justamente da relação com a mãe e

\footnotetext{
100“Un homme, une vieille femme, d'autres femmes ont parlé et leurs voix s'effacent lentement, progressivement, s'étouffent dans la clameur universelle des hommes, qui bat à grands coups comme un coeur partout présent." (EJ, 1973, p. 287)
} 
do silêncio dela. Na primeira nota dos Carnets,Camus escreve sobre essa relação: "Nesse caso particular, o estranho sentimento que o filho tem por sua mãe constitui toda sua sensibilidade.”. ${ }^{01}$ Esse "estranho sentimento" é o que constituirá a sensibilidade tanto do personagem descrito em "Les voix du quartier pauvre" quanto do narrador de "Entre oui et non":

Il commence à sentir beaucoup de choses. À peine s'est-il aperçu de sa propre existence. Mais il a mal à pleurer devant ce silence animal. Il a pitié de sa mère, est-ce l'aimer? Elle ne l'a jamais caressé puisqu'elle ne saurait pas. Il reste alors de longues minutes à le regarder. À se sentir étranger, il prend conscience de sa peine. (EE, 2007, p. 61) ${ }^{102}$

É nesse contexto que a palavra "étranger" aparecerá pela primeira vez nos escritos camusianos. Como destaca Lévi-Valensi (2006, p. 174), essa passagem nos permite saber como esse sentimento de "étrangeté" apareceu no interior do pensamento camusiano e seguir sua primeira expressão em um estado puro, sem o contexto da reflexão filosófica.

Esse sentimento de estranheza continua a ser evocado nos Carnets:

Que signifie ce réveil soudain - dans cette chambre obscure - avec les bruits d'une ville tout d'un coup étrangère ? Et tout m'est étranger, tout, sans un être à moi, sans un lieu où refermer cette plaie. Que fais-je ici, à quoi riment ces gestes, ces sourires ? Je ne suis pas d'ici - pas d'ailleurs non plus. Et le monde n'est plus qu'un paysage inconnu où mon coeur ne trouve plus d'appuis. Étranger, qui peut savoir ce que ce mot veut dire. (C I, 1962, p. 201)

Nessa entrada, podemos perceber que apesar de se perguntar o que essa palavra quer dizer, Camus esboça o que significa essa estranheza: o sentimento de não fazer parte, de se sentir um estrangeiro, um exilado. Essa nota ecoará em uma passagem de Le Mythe de Sisyphe:

\footnotetext{
101 "Dans ce cas particulier, le sentiment bizarre que le fils porte à sa mère constitue toute sa sensibilité." (CI, 1962, p. 15, grifo nosso)

102 “Começa a sentir muitas coisas. Mal se apercebeu da sua própria existência. Mas tem vontade de chorar diante daquele silêncio animal. Tem dó da mãe, será isso amá-la? Ela nunca o acariciou porque não saberia como. Fica então longos minutos a olhá-la. A sentir-se estranho, toma consciência da sua pena.” (EE, 19-?, p. 57)

103 “O que significa essa revelação repentina - nesse quarto obscuro - com os barulho de uma cidade subitamente estranha? E tudo me é estranho, tudo, sem um ser por mim, sem um lugar onde fechar essa ferida. O que eu faço aqui, com que rimam esses gestos, esses sorrisos? Eu não sou daqui - nem de outro lugar. E o mundo nada mais é do que uma paisagem desconhecida onde meu coração não encontra descanso. Estrangeiro, quem pode saber o que essa palavra quer dizer.” (tradução nossa)
} 
Un monde qu'on peut expliquer même avec de mauvaises raisons est un monde familier. Mais au contraire, dans un univers soudain privé d'illusions et de lumières, l'homme se sent un étranger. Cet exil est sans recours puisqu'il est privé des souvenirs d'une patrie perdue ou de l'espoir d'une terre promise. (MS, 2008, p. 20) ${ }^{104}$

Aqui a estranheza será explicitamente descrita como o sentimento de ser um estrangeiro e um exilado. Mas trata-se de um exilado diferente, uma vez que ele não tem a lembrança de uma pátria perdida e nem a esperança de para lá voltar, numa clara referência à negação da transcendência, muito evocada no cristianismo. ${ }^{105}$

Observemos que na nota dos Carnets há também uma inquietação por parte de Camus a respeito do significado da palavra "étranger", que será justamente o título que ele escolherá para a narrativa entre outros: "O Indiferente", "O Pudor", "Um homem feliz", "Um homem livre", "Um homem como todos os outros". ${ }^{106}$ Podemos perceber que "étranger" é muito mais simbólico que os outros títulos e conteria ao mesmo tempo a ideia de um homem estranho/estrangeiro ${ }^{107}$ a si mesmo, aos outros e ao mundo, tal como descrito em Le Mythe de Sisyphe.

Em outra nota dos Carnets, o escritor liga o sentimento de estranheza, o silêncio e a criação:

Étranger, avouer que tout m'est étranger.

Maintenant que tout est net, attendre et ne rien épargner. Travailler du moins de manière à parfaire à la fois le silence et la création. Tout le reste, tout le reste, quoi qu'il advienne, est indifférent. (C I, 1962, p. 202) $)^{108}$

Ao relacionar esses três elementos, nos perguntamos como expressar esse silêncio através das palavras. Podemos pensar primeiramente em uma poética do silêncio sob a qual Camus teria construído seu personagem Meursault. Em Le Mythe de Sisyphe ele escreve que um homem é

\footnotetext{
104،Um mundo que se pode explicar, mesmo com raciocínios errôneos, é um mundo familiar. Mas num universo repentinamente privado de ilusões e de luzes, pelo contrário, o homem se sente um estrangeiro. É um exílio sem solução, porque está privado das lembranças de uma pátria perdida ou da esperança de uma terra prometida." (MS, 2008, p. 20)

${ }^{105}$ Cf. Felipenses 3:20: "Pois a nossa pátria está nos céus, de onde também aguardamos o Salvador, o Senhor Jesus Cristo." e I Pedro 2:11: "Amados, exorto-vos, como peregrinos e forasteiros que sois, a vos absterdes das paixões carnais, que fazem guerra contra a alma.".

${ }^{106}$ Cf. MILHOT, Laurent «Le métatexte camusien : titres, dédicaces, épigraphes, préfaces » In: Albert Camus, cuvre fermée, cuvre ouverte?(1982, p. 291).

${ }^{107} \mathrm{Na}$ língua francesa a palavra étranger contém ao mesmo tempo o sentido de estrangeiro, estranho e alheio, significação que não pode ser reproduzida em português.

108 "Estranho, confessar que tudo me é estranho. Agora que tudo está claro, esperar e não poupar nada. Trabalhar ao menos de maneira a aperfeiçoar ao mesmo tempo silêncio e criação. Todo o resto, todo o resto, o que quer que aconteça, é indiferente.” (tradução nossa)
} 
mais um homem pelas coisas que silencia do que pelas que diz. ${ }^{109} \mathrm{Na}$ narrativa, é o próprio Meursault quem se reconhece como um homem taciturno e fechado; por não ter nada a dizer, ele se cala. ${ }^{110}$ Como no caso do silêncio da mãe, seu silêncio é também ligado à sua indiferença. Essa indiferença se expressa por meio da linguagem, assunto que aprofundaremos no próximo capítulo.

Até este momento abordamos o tema da estranheza, mas não podemos fazê-lo sem que o relacionemos ao absurdo. A descoberta do Absurdo também tem um início insignificante nos escritos camusianos. ${ }^{111} \mathrm{O}$ narrador de "Entre oui et non" relembra que em certas circunstâncias, diante do silêncio da mãe, interpelava-a: "No que você está pensando?" - Em nada, ela respondia. Essa mesma passagem reaparecerá em Le Mythe de Sisyphe, ligada agora ao sentimento de absurdidade:

Dans certaines situations répondre: "rien" à une question sur la nature de ses pensées peut être une feinte chez un homme. Les êtres aimés le savent bien. Mais si cette réponse est sincère, si elle figure ce singulier état d'âme où le vide devient éloquent, où la chaîne des gestes quotidiens est rompue, où le coeur cherche en vain le maillon qui la renoue, elle est alors comme le premier signe de l'absurdité. (MS, 2008, p. 28) ${ }^{112}$

Esse nada, esse vazio, esse silêncio é o que rompe de repente com a corrente dos gestos quotidianos e o homem tenta em vão reencontrar o elo que a liga; é esse distanciamento que dá à luz o absurdo. Assim, a relação com a mãe se torna fundamental para a consciência do absurdo, uma vez que o narrador relaciona o silêncio da mãe ao silêncio do mundo: "A indiferença

${ }^{109}$ (MS, 2008, p. 99) "Un homme est plus un homme par les choses qu'il tait que par celles qu'il dit." (MS, 2008, p. 117)

110“'Il m'a d'abord dit qu'on me dépeignait comme étant d'un caractère taciturne et renfermé et il a voulu savoir ce que j'en pensais. J'ai répondu: «C'est que je n'ai jamais grand-chose à dire. Alors je me tais.»” (Et, 1996, p. 68) “[...]s'il avait remarqué que j'étais renfermé et il a reconnu seulement que je ne parlais pas pour ne rien dire.” (Et, 1996, p. 92)

111، Toutes les grandes actions et toutes les grandes pensées ont un commencement dérisoire. Les grandes oeuvres naissent souvent au détour d'une rue ou dans le tambour d'un restaurant. Ainsi de l'absurdité. Le monde absurde plus qu'un autre tire sa noblesse de cette naissance misérable." (MS, 2008, p. 28)

112 "Em certas situações, responder 'nada' a uma pergunta sobre a natureza de seus pensamentos pode ser um finta de um homem. Os seres amados sabem bem disto. Mas se a resposta for sincera, se expressar aquele singular estado de alma em que o vazio se torna eloquente, em que se rompe a corrente dos gestos cotidianos, em que o coração procura em vão o elo que lhe falta, ela é então um primeiro sinal do absurdo.” (MS, 2008, p. 27) 
daquela mãe estranha! Só esta imensa solidão do mundo me dá a consciência dela." ${ }^{113}$ O silêncio é central para a consciência do absurdo, uma vez que ele nasce exatamente entre a confrontação do apelo humano ao "silêncio irracional do mundo" (MS, 2008, p. 46).

Podemos observar assim que o tema da estranheza nascida da indiferença e do silêncio segue um movimento em espiral: ele liga-se primeiramente a uma narrativa, aparecendo por meio da relação entre a mãe e o filho, para se delinear em Le Mythe de Sisyphe como um sentimento de não fazer parte, de se sentir um estrangeiro. A relação de estranheza se dá agora entre o homem e mundo e é nomeada de absurdo. Em L'Étranger, todos os aspectos do tema serão contemplados: de um lado notamos a estranheza, a indiferença e o silêncio no próprio personagem; de outro, notamos a distância que separa Meursault da sociedade. E, embora o silêncio da mãe não esteja presente em L'Étranger,ele será assimilado e representado simbolicamente pela indiferença e pelo silêncio do mundo.

No entanto, como ressalta Gassin (1981, p. 124), o silêncio tem para Camus dois símbolos: ele se liga ao mesmo tempo ao silêncio da morte, do diálogo negado e do absurdo e ao silêncio do amor, da comunhão e da revelação. É somente no silêncio que filho e mãe podem se amar, e não se trata de um silêncio absoluto, pois eles se comunicam, muitas vezes, pela mediação de sorrisos e olhares. Em "Entre oui et non”, essa impossibilidade do diálogo é sustentada por olhares e por sorrisos: "Mas os seus olhares encontram-se [...] E um belo sorriso sem lábios funde-se na sua cara. É verdade, ele nunca lhe falou. Mas para quê, na verdade? Ao calar-se, a situação esclareceu-se. Ele é seu filho, ela é sua mãe.". ${ }^{114}$ Nessa passagem, é o silêncio e não as palavras que esclarecem. Um sorriso pode ser eloquente, como podemos observar em $L a$ Mort Heureuse:

Auparavant, la pauvreté près de sa mère avait une douceur. Lorsqu'il se retrouvaient le soir et mangeaient en silence autour de la lampe à prétole, il y avait un bonheur secret dans cette simplicité et ce retranchement. Le quartier autour d'eux était silencieux. Meursault regardait la bouche lasse de sa mère et souriait et souriait. Elle souriait aussi. ${ }^{115}$

\footnotetext{
113 (EE, 19-?, p. 58) “L'indifférence de cette mère étrange! Il n'y a que cette immense solitude du monde qui m'en donne la mesure.” (EE, 2008, p. 63)

${ }^{114}$ (EE, 19-?, p. 64) "Mais leurs regards se rencontrent [...] Et un beau sourire sans lèvres se fond sur son visage. C'est vrai, il ne lui a jamais parlé. Mais quelle besoin, en vérité? À se taire, la situation s'éclaircit. Il est son fils, elle est as mère." (EE, 2008, p. 68)

115 “Antes, a pobreza junto da mãe tinha uma certa ternura. Quando se reencontravam ao anoitecer e comiam em silêncio à volta do lampião a querosene, havia uma felicidade secreta naquela simplicidade e naquele recolhimento.
} 
Em L'Étranger, na cena em que Marie visita Meursault na prisão, temos a descrição feita por Meursault do encontro entre uma mãe e um filho: em meio ao barulho de todas as conversas, chama a sua atenção uma ilha de silêncio na qual mãe e filho se olhavam. Também a relação entre Meursault e sua mãe era mediada por olhares, eles não tinham mais o que se falar, no entanto, ele não deixava de observar que sua mãe passava todo o tempo a segui-lo com o olhar (Et, 1996, p. 11).

O silêncio da mãe é permeado por uma terna indiferença, a mesma que Meursault, perto da morte, descobre no mundo. O silêncio da indiferença é também o silêncio do amor: é somente dessa forma que o homem pode se relacionar com o mundo.

O bairro à volta da casa deles era silencioso. Meursault olhava a boca cansada da mãe e sorria. Ela também sorria." (MF, 1997, p. 29) 


\section{Disparei quatro vezes contra um corpo inerte...}

A primeira vez que o tema do assassinato aparece é no ensaio "La Mort dans l'âme"; o narrador relata a cena que viu em um hotel onde estava hospedado em Praga: um homem morto sobre a cama. Ele ressalta que sabia que não se tratava de um suicídio. Essa experiência o marca de tal maneira que mesmo quando se encontra na beleza das planícies italianas ele sente o odor de morte e de desumanidade que o persegue há um mês (EE, 2007, p. 93).

Nessa passagem do ensaio, podemos vislumbrar dois temas que Camus desenvolverá em seus ensaios de natureza mais reflexiva: o suicídio em Le Mythe de Sisyphe e o assassinato em L’homme révolté, publicado em 1950. Em Le Mythe de Sysiphe, o autor explica que o suicídio é um problema filosófico, ${ }^{116}$ enquanto em L’Homme Révolté o assassinato será um problema de ordem moral. $^{117}$

No entanto, essa reflexão moral está ausente em L'Étranger; aqui o assassinato é encarado com a mesma indiferença da morte natural da mãe, ela não inspira comoção nem arrependimento. O absurdo, porém, não recomenda o crime, mas restitui sua inutilidade ao remorso (MS, 2008, p. 96).

O tema do assassinato, porém, fora explorado literariamente em suas primeiras narrativas: La Mort Heureuse e L'étranger. Essas obras estão ligadas profundamente pela cena do assassinato, espécie de "crime original" das narrativas, cuja importância é também estrutural. Ambos os textos sustentam a mesma estrutura: duas partes. $\mathrm{O}$ assassinato cometido por Meursault assegura a passagem da primeira para a segunda parte, e o de Mersault, mesmo tendo sido colocado no início da narrativa, estabelece a passagem da primeira parte "Mort Naturelle" para a segunda, nomeada de "Mort Consciente". Nos dois casos o assassinato define um antes e um depois na vida dos personagens, assim como no texto.

O primeiro dado a observar sobre o assassinato de La Mort Heureuse, e o que muitos críticos já notaram, é que ele parece ter sido inspirado no assassinato de Crime e Castigo: o

\footnotetext{
116 "Il n'y a qu'un problème philosophique vraiment sérieux: c'est le suicide. Juger que la vie vaut ou ne vaut pas la peine d'être vécue, c'est répondre à la question fondamentale de la philosophie. Le reste, si le monde a trios dimensions, si l'esprit a neuf ou douze categories, vient ensuite." (MS, 2008, p. 18)

${ }^{117}[. .$.$] le seul problème moral vraiment sérieux, c'est le meurtre. Le reste vient après. Mais de savoir si je puis tuer$ cet autre devant moi, ou consentir à ce qu'il soit tué, savoir que je ne sais rien avant de savoir si je puis donner la mort, voilà ce qu'il faut apprendre » (E, 1981, p. 172).
} 
personagem pobre que mata para roubar. ${ }^{118}$ Por consequência, o segundo dado é que esse fora um crime premeditado. Há ainda a descrição muito forte do assassinato na narrativa, o tiro que atinge a cabeça de Zagreus deixa a mostra uma massa de cerébro, osso e sangue (OC I, 2006, p. 1007). Sobre a elaboração romanesca dessa cena, André Abou escreve:

$\mathrm{O}$ assassinato, mais discreto do que secreto, aparentemente crapuloso, se torna o signo paradoxal de uma fraternidade eletiva e superior: Zagreus tentado pela morte, só aceitava morrer para liberar Mersault, o qual consentia ao assassinato para pôr fim à desgraça de seu amigo. ${ }^{119}$

Essa "fraternidade sangrenta" $" 120$ pode ser melhor compreendida se for analisada simbolicamente: na mitologia grega Zagreus é um dos filhos adúlteros de Zeus. Ele é devorado pelos titãs por ordem de Hera, mas seu coração é preservado. Zeus encontra uma maneira de fazê-lo nascer uma segunda vez: ele é assimilado por Dionísio. Na perspectiva do mito, o assassinato de Zagreus pode ser lido como um segundo nascimento de Mersault, mas dessa vez para uma vida de gozo, representada pelo dionisíaco: "E a partir desse momento, por causa de um único gesto calculado com toda a lucidez, sua vida mudara, e a felicidade lhe parecia possível. Sem dúvida, ele dera à luz esse novo ser com sofrimento.” (MF, 1971, p. 84). Esse fato talvez explique por que Mersault não sente remorso, nem tampouco se arrepende de seu ato, ausência de arrependimento que será assimilada por Meursault. Essa ausência justifica-se pelo fato de que Mersault não se sente culpado, ${ }^{121}$ nem tampouco Meursault. ${ }^{122}$

No assassinato descrito em L'Étranger, Meursault nos narra sua ida à praia, a briga com os árabes, o retorno para a cabana e em seguida seu retorno à praia, sozinho. Tudo se passa na mais profunda gratuidade. Na cena da briga, Meursault somente observa, em posse da arma, que poderia atirar ou não. Quando retorna à cabana e decide voltar para a praia, ele pensa que seria

\footnotetext{
${ }^{118}$ André Abou, nos comentários escritos para as obras completas de Camus, afirma que além dessa reminiscência literária, podemos observar na cena do assassinato um eco de um caso que acontecera em Argel em setembro de 1937. L'Écho d'Argel tratava assim o caso do assassinato de uma senhora pelo moço que ela havia criado: "Rue de la Liberté, um garçon de dix-huit ans assomme as bienfaitrice.[Je voulais La dévaliser, je ne voulais pas la tuer, j'avais le vivre et le couvert. Mais je voulais pouvoir m'amuser." (OC I, 2006, p. 1447).

119،Le meurtre lui-même, aussi discret que secret, apparamment proche du crime crapuleux, devenait le signe paradoxal d'une fraternité elective et supérieure : Zagreus tenté par la mort, n'acceptait de mourir que pour libérer Meursault, lequel consentait au meurtre pour mettre un fin à la détresse de son ami. (OC I, 2006, p. 1451)

120 "Il se prenait d'un amour violent et fraternel pour cet homme dont il s'était senti si loin et il comprenait qu'à le tuer il avait consommé avec lui des noces qui les liaient à tout jamais." (OC I, 2006, p. 1195)

121 "Dans l'innocence de son coeur, il acceptait ce ciel vert et cette terre mouillé d'amour avec le meme tremblement de passion et de désir que lorqu'il avait tué Zagreus dans l'innocence de son coeur." (OC I, 2006, p. ?)

122 “[...] pour la première fois, j’ai compris que j'étais coupable." (Et, 1996, p. 90)
} 
indiferente ficar lá ou sair, e resolve retornar à praia. Ele encontra novamente o árabe e se surpreende: para ele, a história já tinha acabado na briga e ele retornara àquele lugar sem pensar. Então ele reflete que poderia dar meia volta e ir embora. Mas ele não volta para casa; ao contrário, dá um passo à frente. É então que tudo se precipita: o árabe mostra-lhe a faca, a natureza desempenha seu papel e ele atira. Na mesma gratuidade ele dá mais quatro tiros no corpo inerte e com o barulho dos disparos vem a compreensão de que ele havia destruído o equilíbrio do dia, o silêncio excepcional de uma praia onde ele havia sido feliz. O assassinato é assim o que transporta Meursault da felicidade à desgraça.

A diferença entre o crime cometido por Mersault e Meursault é que no primeiro caso o assassinato é camuflado em suicídio e o assassino escapa, enquanto no segundo o criminoso é preso. Para alguns críticos essa diferença relaciona-se com a mudança do nome do protagonista; o acréscimo da letra "u" na passagem do nome Mersault para Meursault pode ser associado à palavra "meurtrier" do francês. ${ }^{123}$ Em L'Étranger o assassino não somente é preso como é julgado: o assassinato coloca a questão das circunstâncias atenuantes, das motivações e da responsabilidade.

Como vimos, na primeira parte da narrativa o personagem se insere em uma pura contingência de atos, nada é planejado ou premeditado. Na segunda parte, o sistema judiciário procura um sentido, uma intenção para os atos de Meursault. O procurador chega a refazer todas as circunstâncias do crime, desde a morte da mãe no asilo, passando pela relação com Raymond, até a cena da praia:

Et voilà, messieurs, a dit l'avocat général. J'ai retracé devant vous le fil d'événements qui a conduit cet homme à tuer en pleine connaissance de cause. J'insiste là-dessus, a-t-il dit. Car il ne s'agit pas d'un assassinat ordinaire, d'un acte irréfléchi que vous pourriez estimer atténué par les circonstances. (Et., 1996, p. 100) $)^{124}$

\footnotetext{
123 Cf. QUILIOT (TRN, p. 1913), que afirma que a letra $u$ só aparece no final do manuscrito n. 1. Cf. também Dictionnaire Albert Camus na entrada "Meursault": a relação entre os nomes de Mersault e Meursault "é talvez o meio de inscrever profundamente na lógica do personagem a constatação que, uma vez cometido o assassinato, Meursault se encontra privado de mer (de mère?), privado de sua liberdade e entregue inteiramente a eminência de sua própria morte" (2006, p. 553).

124 "E aqui está, meus senhores - disse o advogado de acusação. - Acabo de traçar o fio dos acontecimentos que levaram este homem a matar com pleno conhecimento de causa. Insisto neste ponto. Pois não se trata de um crime banal, de um ato impensado que poderia ser atenuado pelas circunstâncias.” (Et, 1979, p. 271)
} 
Mas o fato é que em L'étranger também o assassinato está envolvido pelo absurdo, em primeiro lugar porque o crime que Meursault comete não tem nenhuma motivação, ele não é movido por ódio ou emoções íntimas. Ele mata um homem com quem não tem nenhuma relação.

O juiz deseja saber por que ele ainda atirou mais quatro vezes em um corpo inerte, Meursault não sabia responder o porquê. O procurador, por sua vez, explica que o acusado atira ainda mais quatro vezes conscientemente e para ter certeza de que o negócio ficara bem feito.

Esse ato, porém, relaciona-se com o absurdo e aparece pela primeira vez em um dos primeiros textos de Camus, em "Perte de l'être aimé", o personagem se desespera diante do corpo da amada, um corpo inerte que nada mais significa nesse mundo: "esta pedra que só pode ser ela porque eu acredito" (EJ, 1973, p. 228). Num gesto de raiva o personagem esbofeteia a morta. ${ }^{125}$ Reencontramos em Le Mythe de Sisyphe o mesmo gesto:

Tous les beaux discours sur l'âme vont recevoir ici, au moins pour un temps, une preuve par neuf de leur contraire. De ce corps inerte où une gifle ne marque plus, l'âme a disparu. Ce côté élémentaire et définitif de l'aventure fait le contenu du sentiment de l'absurde. (MS, 2008, p. 32)

Um tapa nada mais significa, pois a alma já não mais existe. Da mesma forma, um ou cinco tiros não fazem diferença: "Voltei então a disparar mais quatro vezes contra um corpo inerte, onde as balas se enterravam sem se dar por isso.". ${ }^{127}$ Esses quatro tiros seguintes diferentemente do primeiro, quando o árabe ainda está vivo - nada mais significam para esse corpo inerte que não pode se dar conta de que é penetrado por balas: eles somente marcam que a alma desapareceu.

O que fica claro no julgamento é que os atos de Meursault "não fazem sentido" para o procurador e o juiz. Eles tentam achar uma lógica para seu crime. Esse desejo relaciona-se com aquele descrito em Le Mythe de Sisyphe: o desejo desvairado de clareza cujo apelo ressoa no mais profundo do homem (MS, 2008, p. 30). Segundo Rosenfeld, esse tribunal introjeta nele motivos que não tivera, maldades que não conhecera, uma coerência de atitudes que ignorara.

\footnotetext{
${ }^{125}$ Encontramos uma variante no texto, podemos continuar lendo: "Il regarda sans bienveillance le corps. Une pensée lui vint qui le fit frissonner: sa gifle n'avait laissé aucune trace. Vivante, le sang aurait afflué aux endroits meurtris. Et puis aussi la bonne complexité d'une révolte aurait jailli. Il alla se laver les mains. Il sentait au bout de ses doigts la lourde inertie de la tête." (EJ, Origine et établissement des textes, 1973, p. 300).

126، Todos os belos discursos sobre a alma fazem aqui, pelo menos por um tempo, uma prova dos nove ao seu contrário. A alma desapareceu desse corpo inerte onde uma bofetada não marca mais." (MS, 2008, p. 31)

${ }^{127}$ (Et, 1979, p. 224) "Alors, j'ai tiré encore quatre fois sur un corps inerte où les balles s'enfonçaient sans qu'il y parût."
} 
Tentam fazer dele um personagem de romance tradicional para poder condená-lo (1993, p. 94). A oposição entre a narração do crime feita por Meursault e como o tribunal entende o mesmo crime é fundamental em L'Étranger, uma vez que o absurdo só pode nascer de uma comparação (sua compreensão não pode se dar por meio do simples exame de um fato ou de uma constatação) entre um estado de fato e uma certa realidade, uma ação e o mundo que a supera (MS, 2008, p. $50)$. 


\section{Peço-vos a cabeça deste homem...}

\subsection{Uma preparação para a morte}

Para Camus, a doença é uma preparação para a morte, ela cria um aprendizado cuja primeira etapa é o enternecimento para consigo mesmo e apoia o homem no seu grande esforço que é o de se furtar à certeza de morrer totalmente (N, 2008, p. 29).

O primeiro texto de Camus sobre o tema permaneceu na forma de um manuscrito: “L’hôpital du quartier pauvre”, de 1933 (EJ, 1973, p. 241). Toda a ação se resume à saída matinal de um grupo de tuberculosos para tomar sol no jardim, o único assunto da conversação entre aqueles homens é a doença e a morte dos tuberculosos. Eles repetem frases para tentar colorir de esperança o futuro: "A tuberculose é a única doença que nós sabemos curar. É preciso somente tempo." (EJ, 1973, p. 75). Eles repetem também histórias de um tuberculoso que morreu com 62 anos, ou a de Jean Perès, que retornou para a casa e acabou morrendo de tanto fazer sexo com a mulher. Esse texto de 1933 é importante, pois será recuperado em La Mort Heureuse em uma passagem em que Mersault está no restaurante. O filho do dono, tuberculoso, comia, enquanto um freguês lhe explicava que a tuberculose se cura com o tempo. Em seguida, é evocada a história de Jean Pérez ${ }^{128}$ na íntegra. Esses momentos não mais serão evocados na narrativa, no entanto, a doença continuará presente na história. A mãe de Mersault morre de uma longa e penosa doença. ${ }^{129}$ Outro personagem da narrativa, Zagreus, teve as duas pernas amputadas. Ele ressalta que um corpo doente e enfraquecido está privado da alegria, e diz a Mersault que sendo um homem saudável seu único dever é viver é ser feliz (MF, 1997, p. 48).

Finalmente Mersault também é acometido por uma doença, que contrai possivelmente no dia do assassinato que comete. Essa estrutura já adianta aquela que será empregada em L'Étranger, na qual uma morte se relaciona intrinsecamente com a outra: "aquele que matara ia morrer" (OC I, 2006, p. 1193). Relação explicitada pelos títulos das duas partes: a primeira chamada de "Mort Naturelle" e a segunda de "Mort Consciente". Na segunda parte, após

\footnotetext{
${ }^{128}$ Nesse texto a grafia do nome é mudada.

${ }^{129}$ (MH, 1971, p. 28) "Et pendant dix ans, la malade supporta cette vie. Ce martyre avait tant duré que ceux qui l'entourait prirent l'habitude de sa maladie et oublièrent qu'atteinte gravement elle pouvait succomber. Elle mourut un jour." (OC I, 2006, p. 1112)
} 
desfrutar do dinheiro que roubou de Zagreus, Mersault cai de cama pela primeira vez e entre as tosses, o sangue e os tremores o personagem toma consciência da sua doença. A consciência da doença se torna, assim, a consciência da morte que se aproxima. Mas Mersault não deseja morrer como um doente, ele não quer que a doença seja o que tantas vezes é: uma atenuação e como que uma transição para a morte. Ao contrário, ele desejava encontrar-se com ela com sua vida plena de sangue e de saúde.

Mersault deseja manter a consciência até o fim e morrer de olhos abertos. ${ }^{130}$ Os olhos abertos são uma metáfora da lucidez diante da morte, uma ideia cara ao pensamento camusiano. ${ }^{131}$ Ela possui alguns sinônimos em seus escritos, como "eveil", "clairvoyance", “conscience”. Em L'Envers et L'Endroit lemos que a grande coragem é ter os olhos abertos tanto para a luz quanto para a morte (EE, 2007, p. 119). É por esse motivo que o condenado, certo de sua morte, não teme mais as doenças. Em uma nota dos Carnets, podemos ler:

J'ai froid. Comme Il fait froid. Pourquoi m'a-t-on laissé en bras de chemise ? Il est vrai que cela n'a plus d'importance. Il n'y a plus de maladies pour moi. J'ai perdu le paradis de la souffrance, je le perds, et la joie de cracher ses poumons ou d'être mordu par un cancer sous le regard d'un être cher. ${ }^{132}$ (C I, 1962, p. $143)^{133}$

Esse fato se dá porque o condenado é extremamente lúcido de seu destino de morte: "O certo é que vão cortar-lhe o pescoço e enquanto ele está lúcido - enquanto toda sua lucidez se concentra no fato de que vão cortar-lhe o pescoço.". ${ }^{134}$

\footnotetext{
${ }^{130}$ (MF, 1997, p. 137) "La fièvre l'y aidait et avec elle cette certitude exaltante qu'il avait de maintenir sa conscience jusqu'au bout et de mourir les yeux ouverts." (OC I, 2006, p. 1195)

${ }^{131} \mathrm{O}$ termo aparece em uma das primeiras notas dos Carnets I de maio de 1935; a palavra absurdité está ligada a lucidité (1962, p. 23). A ligaçãoo entre a lucidez e o absurdo pode ser melhor compreendida em uma nota de março de 1942: 'Parvenu à l'absurde, s'essayant à vivre en conséquence, un homme s'aperçoit toujours que la conscience est la chose du monde la plus difficile à maintenir. Il s`agit de vivre la lucidité dans un monde où la dispersion est la règle." (1965, p. 19).

${ }^{132}$ Essa notação está inserida nos Carnets I entre notas que seriam aproveitadas possivelmente para L'Étranger, na passagem em que Meursault aguarda que venham buscá-lo para morrer.

133، "Estou com frio. Como faz frio. Porque me deixaram em mangas de camisa? É verdade que isso não tem importância. Não há mais doenças para mim. Eu perdi o paraíso do sofrimento, eu o perco e a alegria de cuspir seus pulmões ou de ser mordido por um câncer diante do olhar de um ente querido." (tradução nossa)

134“L'évident c'est qu'on va lui couper le cou et pendant qu'il est lucide - pendant même que toute sa lucidité se concentre sur ce fait qu'on va lui couper le cou.” (C I, 1962, p. 141)
} 
Assim, na passagem de La Mort Heureuse para L'Étranger o movimento em espiral transforma a consciência da morte trazida pela doença em consciência da morte trazida pela pena de morte, mas em ambos os casos os personagens são condenados: o primeiro pela pena de morte metafísica (a condição mortal a que todos os homens estão sujeitos) e o segundo pela pena de morte histórica (a morte que os homens imputam aos outros homens).

Assim, se a morte é uma pena para a qual não há recursos, a consciência se torna o único meio de ter uma morte feliz. Daí o título da primeira narrativa de Camus, La Mort Heureuse, que em um primeiro momento parece contraditório, mas, como o tema do avesso e do direito, sustenta-se por meio da consonância entre a felicidade de viver e de morrer, como planejara uma nota: “Tema: O universo da morte. Obra trágica: obra feliz.". ${ }^{135}$ Nota que ecoa em Le Mythe de Sisyphe quando lemos que se o mito é trágico é porque seu herói é extremamente consciente, a clarividência que deveria ser o seu tormento consuma, ao mesmo tempo, sua vitória. ${ }^{136}$

Em L'Étranger, Meursault também revela-se consciente de sua morte quando confrontado pelo capelão, ${ }^{137}$ e conclui que todos nós estamos irremediavelmente condenados à morte. Dessa lucidez, dessa certeza, Meursault tira a sua felicidade: diante da morte inevitável ele sentia que fora feliz e que ainda o era (Et, 1996, p. 122). Como já citamos, Camus previra para sua narrativa alguns títulos e entre eles encontramos "L'Étranger ou Un homme heureux", o que enfatiza ainda mais o parentesco temático entre La Mort Heureuse e L’Étranger. Parentesco temático também entre o mito de Sísifo e a história de Meursault: mesmo diante da condenação e em meio ao absurdo "é preciso imaginar Sísifo feliz" (CAMUS, 2008, p. 168), como é necessário também imaginar Meursault feliz.

\subsection{Uma doença que não se cura}

Como vimos, a doença será uma referência sutil em L’Étranger, ela aparecerá em seu aspecto grotesco no cachorro de Salamano: uma sarna lhe faz cair todo o pelo e o cobre de manchas e crostas. O narrador nos faz notar a semelhança entre o velho e o cão. Por viverem

\footnotetext{
135 "Thème: L'Univers de la mort. Oeuvre tragique: oeuvre heureuse." (C I, 1962, p. 123)

136 "Si ce mythe est tragique, c'est que son héros est conscient. [...] La clayrvoiance qui devait faire son tourment consomme du même coups as victoire." (MS, 2008, p. 166)

137“Mais j'étais sûr de moi, sûr de tout, plus sûr que lui, sûr de ma vie et cette mort qui allait venir.” (Et, 1996, p. 120)
} 
sozinhos naquele pequeno quarto acabaram por ficar parecidos um com o outro, o velho também possui crostas de feridas avermelhadas e o cabelo ${ }^{138}$ amarelecido e raro (Et, 1996, p. 31). Um dia o cão se perde e o velho não sabe o que fazer. Ele sente um misto de ódio e ternura pelo animal e conta a Meursault sua história: a mulher tinha morrido e ele se sentira só, pedira a um colega que lhe arranjasse um cachorro. O velho exalta o cão: era preciso tê-lo conhecido antes de sua doença, não havia pelo mais bonito. Depois dela, todas as manhãs e tardes o velho cuidava dele com uma pomada. No entanto, o cão sofria de outra doença, e essa não se cura: a velhice. ${ }^{139}$

A velhice, assim como a doença, é também uma aproximação à morte; nesse sentido os personagens idosos são recorrentes nos escritos camusianos. No ensaio "L'Ironie" é narrada a história de uma senhora solitária e de um senhor que queria ser ouvido. Personagens que podemos relacionar àqueles descritos em "Les Voix du quartier pauvre". Nesse texto de juventude, o senhor é descrito como o "homem que tinha nascido para morrer". Seu grande desejo era ser ouvido, mas fora condenado ao silêncio e à solidão e isso significava para ele uma morte próxima. ${ }^{140}$ A velhice se liga nesse texto ao sentimento do absurdo: "No fim de uma vida, a velhice aparece em forma de náuseas.". ${ }^{141}$

A senhora solitária é descrita como a "velha senhora doente", também reduzida ao silêncio e à imobilidade. Aqui a velhice se liga ao sentimento de religiosidade: os santos e o terço são os elementos que ligam a mulher ao divino, ela coloca na religião toda a sua esperança. ${ }^{142}$ Essa ideia reaparecerá em Le mythe de Sisyphe, colocando a esperança, principalmente a de natureza religiosa (Deus e a vida eterna), como contrária ao absurdo, como uma das maneiras de tentar escapar a ele (MS, 2008, p. 53). Para Camus, no entanto, o cristianismo será representado

\footnotetext{
${ }^{138}$ Aqui Meursault utiliza-se da mesma palavra "poil" para descrever tanto o pelo do animal quanto o cabelo do homem (no lugar de "cheveux").

${ }^{139}$ "Mais comme un chien vit moins qu'un homme, ils avaient fini par être vieux ensemble. [...] Mais selon lui, sa vraie maladie, c'était la vieillesse, et la vieillesse ne se guérit pas." [...]

${ }^{140}$ A primeira vez que a figura de um velho calado aparece é em "Intuitions" (EJ, 1973, p. 188): "Mais j'étais gêné par son silence." e em seguida: “[...] mais j'avais la pensée que cet homme allait bientôt mourir me rendit quelque force." (p. 191).

141 "A la fin d'une vie, la vieillesse revient en nausées." (EJ, 1973, p. 277)

${ }^{142}$ No texto de "Les Voix" a evocação da esperança não é explicita: "Les trois objets qu'elle conservait marquaient pour elle le point matériel où commençait le divin. A partir du chapelet, du christ ou du saint joseph, derrière eux, s'ouvrait un grand noir profond où se trouvait Dieu." (EJ, 1973, p. 285). Em "L’Ironie" essa frase sofrerá uma ligeira alteração em seu final, onde se lia "où se trouvait Dieu" podemos ler "où elle plaçait tout son espoir." (EE, 2007, p. $38)$.
} 
como uma religião de velhos e enfermos. ${ }^{143}$ Em nenhum texto o autor descreve um personagem jovem e saudável dedicado à religião. ${ }^{144}$ Em L'Étranger,o enterro religioso que a mãe de Meursault expressara o desejo de ter guarda mais relação com o cumprimento dos ritos religiosos do que com um apego à prática da religião, como no texto de "Les Voix". É nesse sentido que tão próximo da morte, Meursault recusa também a esperança de natureza religiosa representada pelo capelão. O religioso pergunta se ele não possui nenhuma esperança e se ele pensa que vai morrer por completo, ao que ele responde afirmativamente (Et, 1996, p. 117-119).

A solidão ligada à velhice também será explorada nos escritos de Camus. No ensaio "L'Ironie", a velha senhora é deixada em casa enquanto os jovens vão ao cinema. A solidão da velhice a faz pensar na morte, mas ela não deseja estar só, não deseja deixar os homens (EE, 2007, p. 40). Todos os desdobramentos desse tema reaparecerão em L'étranger: a velhice, a solidão, a vida em um asilo e a morte próxima.

A primeira nota para a história do asilo aparece em maio de 1938:

La vieille femme à l'asile de vieillards, qui meurt. Son amie, l'amie qu'elle s'est faite en trois ans, qui pleure «parce qu'elle n'a plus rien». Le concierge de la petite morgue qui est parisien et qui vit là avec sa femme. "Qui leur aurait dit qu'à 74 ans il finirait dans un asile de vieillards à Marengo ?» Son fils a une situation. Ils sont venus de Paris. La belle-fille ne les a pas voulus. Scènes. Le vieux a fini par «lui lever la main». Son fils les a mis aux vieillards. Le fossoyeur qui était l'ami de la morte. Ils allaient quelque fois le soir au village. Le petit vieux qui a tenu suivre le convoi jusqu'à l'église et au cimetière $(2 \mathrm{~km})$. Comme il est infirme, il ne peut tenir le train et marche vingt mètres en arrière. [...] Les amis de la morte: Petits vieux mythomanes. Tout était beau dans le passé. L'un à l'autre : «Votre fille ne vous a pas écrit? - Non. - Elle pourrait se souvenir qu'elle a une mère. »

143 "Petite vieille remuante et bavarde, on l'avait réduite au silence et à l'immobilité. Seule de longues journées, illettrée, peu sensible, sa vie entière se ramenait à Dieu. Elle croyait en lui. Et la preuve est qu'elle avait un chapelet, un christ de plomb et, en stuc, un saint Joseph portant l'Enfant. Elle doutait que sa maladie fût incurable, mais l'affirmait pour qu'on s'intéressât à elle, s'en remettant du reste au Dieu qu'elle aimait si mal." (EE, 2007, p. 35) "On sentait cette vieille femme liberée de tout, sauf de Dieu, livrée tout entière à ce mal dernier, vertueuse par necessité, persuadée trop aisément que ce qui lui restait était le seul bien digne d'amour, plongée enfin, et sans retour, dans la misère de l'homme en Dieu." (EE, 2007, p. 37)

${ }^{144}$ Sobre esta questão ver "L'Été à Alger". Nesse texto Camus ressalta que a Argélia é um país que privilegia a juventude, é a terra de um povo sem religião e sem ídolos: "Cette race est indifférente à l'esprit. Elle a le culte et l'admiration du corps." (p. 45) 
L'autre est morte - comme un signe et un avertissement pour tous. (C I, 1962, p. $110-111)^{145}$

Todos os elementos que serão trabalhados na passagem do velório e do enterro da mãe de Meursault estão presentes nessa nota: a amiga que chora, a história do zelador do asilo, os outros idosos que acompanham o velório e, finalmente, a figura de Thomas Perez. ${ }^{146}$

A conversa em que os idosos reclamam do abandono é suprimida da passagem do velório e do enterro da mãe, mas será retomada em conversa com o velho Salamano. O velho conta a Meursault que no bairro o tinham criticado por ter mandado a mãe para o asilo. Ele responde que o asilo tinha lhe parecido uma coisa muito natural: em primeiro lugar, pois não tinha dinheiro para manter a mãe e, em segundo, porque fazia muito tempo que já não tinham mais o que se falar (Et, 1996, p. 50). No entanto, o fato de ter colocado a mãe no asilo servirá na segunda parte da narrativa como um dos argumentos da acusação.

Em L'Étranger é também interessante observar a maneira como Meursault descreve os idosos do asilo. Perez é descrito em todo o seu patético, ${ }^{147}$ e nos outros idosos temos todo o grotesco da aparência da velhice, ${ }^{148}$ que podemos ligar mais uma vez à imagem do cachorro e de Salamano. Nos textos anteriores há uma valorização do corpo, principalmente do corpo jovem.

\footnotetext{
${ }^{145}$ A velha senhora no asilo de idosos que morre. Sua amiga, a amiga que ela fez nesses três anos que chora "porque ela não tem mais nada.". O zelador da pequena morgue que é parisiense e que vive lá com sua mulher. "Quem diria que aos 74 anos ele terminaria em um asilo em Marengo?". Seu filho tem uma boa situação. Eles vieram de Paris. A nora não os quis. O velho acabou por "levantar a mão" para ela. Seu filho os colocou no asilo. O coveiro que era amigo da morta. Eles iam algumas vezes à cidade. $\mathrm{O}$ velhinho que aguentou seguir o cortejo até a igreja e ao cemitério $(2 \mathrm{~km})$. Como ele estava doente, ele não consegue acompanhar a caravana e anda vinte metros atrás. [...] Os amigos da morta: velhinhos mitomaníacos. Tudo era belo no passado. Um ao outro: "Sua filha não escreveu? Não - Ela poderia se lembrar que tem uma mãe.”. A outra está morta - como um signo e um aviso para todos. (tradução nossa)

${ }^{146}$ Esse personagem aparece ainda em uma segunda nota, de agosto de 1938: "Asile de vieillards (le vieux à travers champs). Enterrement. [...] Il va à l'enterrement parce que c'est sa seule amie. A l'asile, on lui disait comme aux enfants: “Ah c'est votre fiancée.” Et il riait. Et il était content." (C I, 1962, p. 124)

${ }^{147}$ J'ai compris que c'était M. Perez. Il avait un feutre mou à la calotte ronde et aux ailes larges (il l'a ôté quand la bière a passé la porte), un costume dont le pantalon tire-bouchonnait sur les souliers et un nœud d'étoffe noire trop petit pour sa chemise à grand col blanc. Ses lèvres tremblaient au-dessous d'un nez truffé de points noirs. Ses cheveux blancs assez fins laissaient passer de curieuses oreilles ballantes et mal ourlées dont la couleur rouge sang dans ce visage blafard me frappa. (Et, 1996, p. 19)

148 "Je n'avais encore jamais remarqué à quel point les vieilles femmes pouvaient avoir du ventre. Les hommes étaient presque tous très maigres et tenaient des cannes. Ce qui me frappait dans leurs visages, c'est que je ne voyais pas leurs yeux, mais seulement une lueur sans éclat au milieu d'un nid de rides. Lorsqu'ils se sont assis, la plupart m'ont regardé et ont hoché la tête avec gêne, les lèvres toutes mangées par leur bouche sans dents, sans que je puisse savoir s'ils me saluaient ou s'il s'agissait d'un tic. Je crois plutôt qu'ils me saluaient.” (Et, 1996, p. 15)
} 
No entanto, de alguma forma desejamos a velhice ao projetarmos nossa vida no futuro. Em um texto anterior, podemos ler que os homens "constroem sobre a velhice que virá" (EJ, 1973, p. 287), mas ela chega e precisamos de outros homens para nos proteger. A velhice, enfim, nos revela o absurdo. Nós vivemos como se a morte não existisse, como se fôssemos ser jovens para sempre e ao mesmo tempo desejamos o futuro. Grande contradição, o tempo passa e ficamos velhos e confrontados diante da morte que se aproxima:

Nous vivons sur l'avenir: "demain", "plus tard", "quand tu auras une situation", "avec l'âge tu comprendras". Ces inconséquences sont admirables, car enfin il s'agit de mourir. Un jour vient pourtant et l'homme constate ou dit qu'il a trente ans. Il affirme ainsi sa jeunesse. Mais du même coup, il se situe par rapport au temps. Il y prend sa place. Il reconnaît qu'il est à un certain moment d'une courbe qu'il confesse devoir parcourir. Il appartient au temps et, à cette horreur qui le saisit, il y reconnaît son pire ennemi. Demain il souhaitait demain, quand tout lui-même aurait dû s'y refuser. Cette révolte de la chair, c'est l'absurde. $(\mathrm{MS}, 2008, \text { p. 30) })^{149}$

Essa percepção descrita em Le Mythe já havia sido narrada em dois textos anteriores: tornar-se um homem significa tornar-se velho e tornar-se velho significa morrer. ${ }^{150}$

No final da narrativa de L'Étranger, seguindo o mesmo movimento em espiral, assimila a reflexão sobre a velhice à reflexão sobre a pena de morte. Próximo da morte, Meursault se lembra da mãe idosa: "Pela primeira vez depois de muito tempo eu pensei em mamãe.”. Essa frase já havia sido empregada anteriormente, quando Meursault escuta o choro de Salamano por causa do desaparecimento de seu cachorro, ${ }^{151}$ unindo mais uma vez o tema da velhice e da morte.

Enfim, ao pensar na mãe, ele compreende que a consciência da morte trazida pela velhice pode ser uma libertação:

149 "Vivemos no futuro: "amanhã", "mais tarde", "quando você conseguir uma posição", "com o tempo vai entender". Estas inconsequências são admiráveis, porque afinal trata-se de morrer. Chega o dia em que o homem constata ou diz que tem trinta anos. Afirma assim a sua juventude. Mas, no mesmo movimento, situa-se em relação ao tempo. Ocupa nele o seu lugar. Reconhece que está dentro de uma curva que, admite, precisa percorrer. Pertence ao tempo e reconhece seu pior inimigo nesse horror que o invade. O amanhã, ele ansiava o amanhã, quando tudo em si deveria rejeitá-lo. Essa revolta da carne é o absurdo!” (MS, 2008, p. 28)

150 "Être un homme, c'est ce qui compte. [...] Il est maintenant un homme. N'est-ce pas cela qui compte ? Il faut bien croire que non, puisque faire ses devoirs et supporter ses peines, ça conduit à être vieux." (Les Voix du quariter pauvre, p. 79) e em Louis Raingeard: "Cette expérience datait du jour où Luis avait compris, à deux reprises différentes, ce qu'était un homme vieux, [Il avait biffé] s'était aperçu brusquement que faire son devoir et supporter ses peines conduit à être vieux. [La vieillesse est un état bâtard que [mots illisibles] biffés au crayon bleu] (OC I, 2010, p. 90)

151 “Je ne sais pas pourquoi j’ai pensé à maman.” (Et, 1996, p.44) 
Pour la première fois depuis bien longtemps, j'ai pensé à maman. Il m'a semblé que je comprenais pourquoi à la fin d'une vie elle avait pris un «fiancé», pourquoi elle avait joué à recommencer. Là-bas, là-bas aussi, autour de cet asile où des vies s'éteignaient, le soir était comme une trêve mélancolique. Si près de la mort, maman devait s'y sentir libérée et prête à tout revivre. (Et, 1996, p. $121)^{152}$

Diante de sua morte eminente Meursault também se sente pronto para tudo reviver, capacidade que se relaciona com a de Sísifo: a de encarar lucidamente o seu destino. Sentir-se pronto para tudo reviver significa, como no mito de Sísifo, retomar a sua pedra e recomeçar o seu trabalho, mesmo em meio ao absurdo, mesmo sabendo que não há nenhuma possibilidade de transcendência através da morte. A consciência da morte tanto trazida pela velhice como pela condenação são uma libertação: “O absurdo me esclarece o seguinte ponto: não há amanhã. Esta é, a partir de então, a razão da minha liberdade profunda.". ${ }^{153}$

\subsection{A morte certa}

Muitos críticos concordam que a verdadeira obsessão de Camus sempre fora o cadafalso e a guilhotina. ${ }^{154} \mathrm{Um}$ dos manuscritos de L'Étranger, chamado de “manuscrito Millot", contém algumas ilustrações marginais que enfatizam ainda mais a relação entre a morte da mãe e a de Meursault: cavaletes em forma de $\mathrm{X}$ sobre os quais repousam o caixão da mãe e uma guilhotina esquematizada (OC I, 2010, p. 1262). Encontramos uma referência a essa imagem entre as primeiras notas de Camus nos Carnets (C I, 1962, p. 160; 177). Ainda entre essas notas, figura uma que será reaproveitada em sua totalidade para L'Étranger. ${ }^{155}$

\footnotetext{
152 "Pela primeira vez, havia muito tempo, pensei na minha mãe. Julguei ter compreendido por que é que, no fim de uma vida, arranjara um "noivo", porque é que fingiria recomeçar. Também lá, em redor desse asilo onde as vidas se apagavam, a noite era como uma treva melancólica. Tão perto da morte, a minha mãe deve ter-se sentido libertada e pronta a tudo reviver." (Et, 1979, p. 298)

${ }^{153}$ (MS, 2008, p. 70) "L'absurde m'éclaire sur ce point : il n'y a pas de lendemain. Voici désormais la raison de ma liberté profonde.” (MS, 2008, p. 84)

${ }^{154}$ A guilhotina foi usada na França até 1977, sendo abolida em 1981 pela Assembleia Nacional.

155 "J'ai cru longtemps - et je ne sais pas pourquoi — que pour aller à la guillotine, il fallait monter sur un échafaud, gravir des marches. Je crois que c'était à cause de la Révolution de 1789, je veux dire à cause de tout ce qu'on m'avait appris ou fait voir sur ces questions. Mais un matin, je me suis souvenu d'une photographie publiéepar les journaux
} 
A pena de morte foi objeto de um estudo especial em "Réflexions sur la guillotine", de 1957, que figura no livro Réflexions sur la peine capitale. ${ }^{156}$ Camus era totalmente contrário à pena de morte, qualificando-a como um assassinato administrativo e como uma morte premeditada. Se a morte faz parte da natureza humana, a lei não foi feita para imitá-la, mas para corrigi-la. Podemos ler nos Carnets: "Nous ne devons pas condamner à mort, puisqu'on a fait de nous des condamnés à mort.” (C II, 1965, p. 129).

No interior do pensamento camusiano, a pena de morte terá dois desdobramentos: a pena de morte histórica e a pena de morte metafísica. A pena de morte metafísica se refere ao fato de que todos os homens já estão irrefutavelmente condenados à morte. "Réflexions sur la guillotine" tratará principalmente da pena de morte histórica, ou seja, a morte que homens impetram a outros homens. Em L'Étranger, elas coincidem no momento em que o capelão tenta consolar Meursault afirmando que todos estão condenados, mas este afirma que não se tratava de fatos da mesma ordem (Et, 1996, p. 61).

A primeira vez que esse tema aparece nos escritos de Camus é no fechamento do ensaio "Entre oui et non”, onde podemos ler: "Que não digam do condenado à morte: 'Vai pagar a sua dívida à sociedade, mas: 'Vão lhe cortar a cabeça.' Isso parece não ser nada. Mas faz uma pequena diferença. E de resto há pessoas que preferem olhar o seu destino nos olhos.". ${ }^{157}$ Dessa pequena passagem podemos explorar vários aspectos, o primeiro deles é que a morte do condenado é vista não como um pagamento àquilo que ele deve à sociedade, mas apenas como ela de fato é: simplesmente outra morte. O segundo aspecto é a lucidez do condenando ao encarar seu destino, ideia explorada literariamente por Camus já nos Carnets:

Sur l'absurde?

àl'occasion d'une exécution retentissante. En réalité, la machine était posée à même le sol, le plus simplement du monde." (C I, 1962, p. ?)

${ }^{156}$ Dentro do pensamento camusiano, a pena de morte terá dois desdobramentos: a pena de morte histórica e a pena de morte metafísica. A pena de morte metafísica se refere ao fato de que todos os homens já estão irrefutavelmente condenados à morte. "Réflexions sur la guillotine" tratará principalmente da pena de morte histórica, ou seja, a morte que homens impetram a outros homens. Camus era totalmente contrário a pena de morte, qualificando-a como um assassinato administrativo e como uma morte premeditada. Se a morte faz parte da natureza humana, a lei não foi feita para imitá-la, mas para corrigi-la. Podemos ler nos Carnets: "Nous ne devons pas condamner à mort, puisqu'on a fait de nous des condamnés à mort." (C II, 1965, p. 129).

${ }^{157}$ (EE, 19-?, p. 67) "Qu'on ne nous raconte pas du condamné à mort: 'Il va payer sa dette à la société', mais: 'On va lui couper le cou' Ça n'a l'air de rien. Mais ça fait une petite différence. Et puis, il y a des gens qui préfèrent regarder leur destin dans les yeux." (EE, 2007, p. 72) 
Il n'y a qu'un cas où le désespoir soit pur. C'est celui du condamné à mort (qu'on nous permette une petite évocation). On pourrait demander à un désesperé d'amour s'il veut être guillotiné le lendemain, et il refuserait. A cause de l'horreur du supplice ? Oui. mais l'horreur naît ici de la certitude - plutôt de l'élément mathématique qui compose cette certitude. L'Absurde est ici parfaitement clair. [...] L'évident c'est qu'on va lui couper le cou et pendant qu'il est lucide - pendant même que toute sa lucidité se concentre sur ce fait qu' on va lui couper le cou. (C I, 1962, p. 141) $)^{158}$

A certeza da morte nasce aqui de um elemento matemático: em L'Étranger, Meursault reflete se seria possível escapar a esse elemento mecânico, se o inevitável poderia ter uma saída (Et, 1996, p. 109). O aspecto matemático dá a justiça, ao júri e a sentença uma importância capital dentro dessa máquina impassível. Meursault reflete com ironia sobre esses mecanismos: a sentença que o condenara à morte havia sido dada por homens que trocam a roupa de baixo e em nome de uma noção tão abstrata como o povo francês (Et, 1996, p. 110). Nessa reflexão sobre a pena de morte podemos encontrar o absurdo, ou seja, a desproporção entre o crime e sua condenação, entre o julgamento e seu desenrolar imperturbável (Et, 1996, p. 110).

A certeza da morte inflige ao condenado uma pena ainda maior do que aquela que ele infligiu a sua vítima, que não sabia que iria morrer. Em outra nota dos Carnets, muito provavelmente um esboço para uma passagem narrativa, um personagem narra a sua angústia:

J'ai fini par ne plus dormir qu'un peu dans la journée, attendant patiemment dans mes nuits que la lumière éclate et, avec elle, la vérité d'un nouveau jour. Pendant toute l'heure douteuse où je savais qu'ils venaient d'habitude... alors j'étais comme une bête... Après, j'avais encore un jour... [...] Mais ce sont eux. Et pourtant il fait très noir. Ils sont venus plus tôt. Je suis volé. Je vous dis que je suis volé... (C I, 1962, p. 142) ${ }^{159}$

Essa angústia será vivida por Meursault que não mais dormia, ocupando as suas noites a espera do amanhacer, hora em que os condenados eram levados (Et, 1996, p. 113). Assim, a

\footnotetext{
158 "Sobre o Absurdo? Só há um caso em que o desespero pode ser puro. É aquele do condenado à morte (permitamo-nos uma pequena evocação). Poderíamos perguntar a um desesperado de amor se ele gostaria de ser guilhotinado amanhã, e ele se negaria. Por causa do horror do suplício? Sim. Mas o horror nasce aqui da certeza sobretudo do elemento matemático que compõe esta certeza. $\mathrm{O}$ absurdo está aqui perfeitamente claro. [...] $\mathrm{O}$ evidente é que vão cortar-lhe o pescoço enquanto ele está lúcido - enquanto toda a sua lucidez se concentra no fato de que vão cortar-lhe o pescoço." (tradução nossa)

159 "Eu acabei por dormir só um pouco durante o dia, esperando pacientemente nas minhas noites que a luz aparecesse e, com ela, a verdade de um novo dia. Durante toda a hora duvidosa que eu sabia que eles vinham costumeiramente [...] então eu me sentia como uma animal... Depois, eu tinha ainda um dia... [...] Mas são eles. E, no entanto, ainda está escuro. Eles vieram mais cedo. Eu fui pego de surpresa. Eu digo a você que fui pego de surpresa. (tradução nossa)
} 
consciência da morte (tanto a relacionada com a pena de morte quanto a metafísica) se dá também por seu aspecto matemático; lemos em Le Mythe de Sisyphe que são as matemáticas sangrentas da morte que ordenam nossa condição (MS, 2008, p. 32) Mas mesmo essa consciência não pode privar o condenado da angústia da espera.

Embora as notas dos Carnets relatassem o momento em que o condenado seria levado, essa cena não é narrada em L'Étranger. Em Le Mythe de Sisyphe, lemos uma passagem que trata desse momento:

La divine disponibilité du condamné à mort devant qui s'ouvrent les portes de la prison par une certaine petite aube, cet incroyable désintéressement à l'égard de tout, sauf de la flamme pure de la vie, la mort et l'absurde sont ici, on le sent bien, les principes de la seule liberté raisonnable : celle qu'un cœur humain peut éprouver et vivre. (MS, 2008, p. 85)

Mais uma vez, a aproximação à morte conduz a liberdade nascida de uma consciência, isto é, a aceitação da morte e do absurdo sob a chama pura da vida.

\subsection{A alegria da escrita}

A obra de arte, particularmente a literatura, ocupa um grande espaço na reflexão sobre o absurdo em Le Mythe de Sisyphe, pois “o deleite absurdo por excelência é a criação.” (MS, 2008, p. 109). Como vimos nos tópicos anteriores, a lucidez é um ponto fundamental para o homem camusiano e, de todas as escolas de paciência e da lucidez, a criação é a mais eficaz. Ela é o testemunho perturbador da única dignidade do homem, a revolta tenaz contra sua condição, a perseverança num esforço estéril. Mas a obra não tem tanta importância em si mesma quanto na prova que exige de um homem e na oportunidade que lhe oferece para superar seus fantasmas e se aproximar um pouco mais da sua realidade nua (MS, 2008, p. 156).

Essas colocações nos levam a pensar sobre o papel de Meursault enquanto aquele que narra sua história. A segunda parte de L'Étranger se assemelha muito às memórias, por causa de seu caráter retrospectivo. Mas, em nenhum momento, o personagem fala sobre o momento de uma possível escrita. A pergunta que se coloca é: por que ele escreve?

Talvez a experiência da prisão tivesse sido o gatilho para a sua escrita, como ele deixa entrever quando afirma que, quando entrou na prisão, logo compreendeu que não gostaria de falar dessa parte de sua vida, mas que mais tarde não deu mais importância a essas repugnâncias (Et, 
1996, p. 73). Mas, mais que a prisão, talvez outra experiência tivesse tido um papel importante para despertar nele o desejo de escrever: sua condenação à morte e com ela a revelação do absurdo. A criação é exatamente o passo seguinte à indiferença e à descoberta do absurdo, pois ela marca o ponto onde as paixões absurdas se precipitam e onde o raciocínio pára (MS, 2008, p. 132). Ao deparar-se com a morte, Meursault contempla como Sísifo no cume da montanha essa sequência de ações desvinculadas que se tornou seu destino, criado por ele, unido sob o olhar de sua memória e logo selado pela sua morte (MS, 2008, p. 168). Por esse motivo, ao narrar a sua história, ele começa exatamente pela morte da mãe, episódio capital para a compreensão de como ele havia chegado até ali, e que, como vimos, está ligada estruturalmente na narrativa à morte do árabe e à sua própria morte.

Encontramos nos Carnets notas que planejam a história de um condenado à morte que escreve, ${ }^{160}$ muito possivelmente Patrice Mersault de La Mort Heureuse:

Patrice raconte son histoire de condamné à mort : [...]

«Je sais que maintenant je vais écrire. Il vient un temps où l'arbre, après avoir beaucoup souffert, doit porter ses fruits. Chaque hiver se clôt dans un printemps. Il me faut témoigner. Le cycle après reprendra." (C I, 1962, p. 24) ${ }^{161}$

Podemos conjecturar, assim, que esse homem tenha começado a escrever após sua sentença, mas, como vimos, no caso de Mersault, não se trata exatamente da pena capital, mas de sua enfermidade fatal. O fato é que em La Mort Heureuse a narração é feita em terceira pessoa e, em L'Étranger, embora narrado em primeira pessoa, não há essa alusão à escrita.

Em outra nota dos Carnets podemos ler que a morte não faz mais do que exasperar no homem a urgência de criar, de escrever, de testemunhar seu amor pela vida. É por esse motivo que a escrita do condenado à morte não nasce de sua angústia, mas da alegria que ele descobre ao ser confrontado com a morte:

D'autres écrivent par tentation différées. Et chaque déception de leur vie leur fait une œuvre d'art, mensonge tissé de mensonges de leur vie. Mais moi c'est de mes bonheurs que sortiront mes écrits. Même dans ce qu'ils auront de cruel. Il

\footnotetext{
${ }^{160}$ IIIe Partie (tout au présent) Chap. I Cathérine, dit Patrice, je sais que maintenant je vais écrire. Histoire du condamné à mort. Je suis rendu à ma véritable fonction qui est d'écrire. (C I, 1962, p. 25)

161 "Patrice conta sua história de condenado à morte: [...] Eu sei que agora eu vou escrever. Chega um tempo em que a árvore, depois de muito sofrer, deve dar seus frutos. Cada inverno se encerra em uma primavera. É preciso que eu testemunhe. O ciclo depois recomeçará." (tradução nossa)
} 
me faut écrire comme il me faut nager, parce que mon corps l'exige. (C I, 1962, p. 25$)^{162}$

A escrita é assim uma exigência do corpo, é um prazer, uma comunhão: a mesma que o narrador de "Noces à Tipasa" experimenta e que Meursault posteriormente encontrará em seus banhos de mar. Assim ligamos a morte à lucidez, a lucidez à alegria e finalmente a alegria à escritura.

No fim da história de Meursault, o fim da vida e o fim da escrita se unem. A morte pode impedir que a escrita continue, mas não pode nada contra o escrito em si. Ele sobrevive, ele é um apelo à leitura posterior. A obra absurda se coloca assim diante do outro, não para que ele se perca, mas para lhe apontar precisamente a via sem saída na qual todos estão (MS, 2008, p. 132). Assim, se pensarmos Meursault como aquele que escreve a sua história, podemos fabular que talvez o caderno de Meursault tenha sido encontrado entre o colchão e as tábuas da cama, onde ele próprio tinha encontrado aquele pedaço de jornal com a história da Tchecoslováquia.

Os escritos de Meursault sobrevivem a ele, mas isso não significa que ele mesmo tenha sobrevivido à morte ou que através de sua obra escapou do Absurdo. Não há possibilidade de transcendência através da escrita. ${ }^{163}$

A obra não é uma fuga, ao contrário, ela é um dos signos do Absurdo. ${ }^{164}$ Ela não pode ser um fim, o sentido ou a consolação de uma vida. A escrita, e consequentemente a leitura, se tornam então uma grande metáfora da morte feliz, a possibilidade de uma alegria lúcida diante da morte.

\footnotetext{
162 “Outros escrevem por tentações diferentes. E de cada decepção de sua vida faz uma obra de arte, mentira tecida em mentiras de sua vida. Mas eu, é das minhas alegrias que sairão os meus escritos. Mesmo no que eles terão de cruel. Eu preciso escrever, como eu preciso nadar, porque o meu corpo exige." (tradução nossa)

163 “L'existence tout entière, pour un homme détourné de l'éternel, n'est qu'un mime démesuré sous le masque de l'absurde. La création, c'est le grand mime." (MS, 2008, p. 130)

164 "Elle n'offre pas une issue au mal de l'esprit. Elle est au contraire un des signes de ce mal qui le répercute dans toute la pensée d'un homme.” (MS, 2008, p. 131)
} 


\section{A TERNA INDIFERENÇA DE \\ L'ÉTRANGER}

\section{Apresentação}

Segundo a belíssima metáfora de Proust, a obra literária é uma espécie de construção: ela pode se assemelhar tanto à complexa elaboração de uma catedral quanto à aparente simplicidade da costura de um vestido. O estudo do processo de criação do autor de À la Recherche du Temps Perdu mostrou que essa metáfora se ajusta exatamente ao seu próprio fazer literário: tanto o vestido quanto a obra literária só podem ser concretizados na adição de diversas camadas e fragmentos de tecido e textos que deverão ser costurados entre si (HAAG, 2009, p. 100).

$\mathrm{Na}$ análise que empreendemos no segundo capítulo, também pudemos perceber certa agulha imaginária costurando temas, imagens e fragmentos de textos de um livro para outro, formando o grande vestido que chamamos de avesso e de direito. A essa estrutura delicada que só podemos perceber quando chegamos bem perto e observamos as marcas da costura no avesso desse vestido, Camus contrapôs também uma estrutura mais concreta, menos fluida.

Camus constrói o texto como uma casa: na arquitetura de "La Maison Mauresque" cada parte do texto relaciona-se a um espaço: a entrada, o corredor e o pátio. É a passagem dos cômodos fechados para os cômodos a céu aberto que permite representar, através dos jogos de luz e sombra, entre as penumbras azuis e os corredores ensolarados, um princípio que regeria o próprio mundo: o avesso e o direito (EJ, 1973, p. 207). Eis a definição da arquitetura camusiana: essa perene oscilação entre as núpcias e o absurdo, o amor a vida e a presença implacável da morte.

A construção poética de "La Maison Mauresque" será a metáfora para a construção de L'Étranger, na narrativa também se alternam o avesso e o direito. Nosso objetivo, nesse último capítulo, é analisar como a construção dessa casa árabe é uma metáfora do próprio fazer literário de Camus, cujos textos se apoiam e se estruturam a partir do tema do avesso e do direito. Assim, 
passamos pelos primeiros escritos onde essa estrutura foi esboçada para os ensaios de L'Envers et L'Endroit - onde ela toma forma - para chegar à L'Étranger, onde percorremos os pátios ensolarados das praias argelinas e os corredores sombrios da prisão de Meursault. 


\section{Duas partes: inseparáveis e complementares}

L'Étranger é dividido em duas partes: a primeira dá conta da vida de Meursault até o assassinato, enquanto a segunda trata de seus dias na prisão, seu julgamento e sua condenação.

Essas partes possuem o mesmo tamanho, respectivamente seis e cinco capítulos, sendo que o capítulo seis da primeira parte ocupa a posição central da narrativa, tanto no que se refere à estrutura quanto ao enredo.

Essa estrutura bipartida é sustentada por um grande número de paralelismos e oposições. Por exemplo, o paralelo estabelecido entre os velhos do asilo e o público no tribunal, ${ }^{165}$ por quem Meursault se sente duplamente julgado; entre seu quarto e sua cela, ${ }^{166}$ espaços desprovidos de mobília e nos quais ele vive solitário. Há ainda a oposição entre os personagens que aparecem na primeira parte e reaparecem na segunda; entre as ações sem ressonâncias da primeira parte, mas que reaparecem no julgamento como agravantes. A principal oposição a ser citada é entre um fora e um dentro: as praias argelinas e a prisão. Enfim, trata-se de uma oposição entre um avesso e um direito, entre um tempo de liberdade e o encerramento, entre a vida em comunhão com a natureza e a condenação à morte.

Essa estrutura já pode ser percebida em uma das primeiras notas dos Carnets, escrita muito possivelmente a propósito de La Mort Heureuse. São apresentadas seis histórias ${ }^{167}$ em que parece haver uma espécie de alternância entre um direito: de um lado "o jogo brilhante", o "luxo" e a "Casa diante do Mundo", que se contrapõe a um avesso: "o bairro pobre", a "morte da mãe" e a história do "condenado à morte". Apesar dessa ideia de alternância, podemos ler em um plano posterior que essa história contaria possivelmente com três partes: sua vida até então (o jogo), o abandono dos compromissos e a verdade na natureza. ${ }^{168}$

É muito provável que Camus tenha percebido que essa estrutura tripartida não se ajustaria bem à ideia de alternância, o que o leva a mudar a estrutura da narrativa, que passa a contar apenas com duas partes, nomeadas como "Morte Natural" e "Morte Consciente". No entanto, essa reorganização parece artificial, pois se trata na verdade de uma redisposição das histórias

\footnotetext{
165 “J'ai eu un moment l'impression ridicule qu'ils étaient là pour me juger.” (Et, 1996, p. 15)

166 “j'ai senti que j'étais chez moi dans ma cellule et que ma vie s'y arrêtait.” (Et, 1996, p. 73)

167 "6 histoires: Histoire du jeu brillant. Luxe./ Histoire du quartier pauvre. Mort de la mère./ Histoire de la Maison devant le Monde./ Histoire de la jalousie sexuelle./ Histoire du condamné à mort./ Histoire de la descente vers le soleil. (C I, 1962, p. 26)

168 "I ${ }^{\text {re }}$ Partie - Sa vie jusque-là/II ${ }^{\mathrm{e}}$ Partie - Le Jeu/III ${ }^{\mathrm{e}}$ Partie - L'abandon des compromis et la vérité dans la nature." (C I, 1962, p. 62)
} 
entre duas partes, fato que fica ainda mais flagrante na dissemetria existente entre elas (49 e 91 páginas, respectivamente). Teria sido preciso, antes, reescrever essas histórias de modo que elas se reorganizassem conservando a ideia de alternância. Como sabemos, o escritor abandona esse projeto e passa a trabalhar na escritura de L'Étranger, onde essa estrutura bipartida é mantida.

Na nota que previa três partes para a composição de La Mort Heureuse, a descrição "da vida até então" do personagem pode ser relacionada com a primeira parte de L'Étranger: os banhos de mar, o trabalho, a relação com os vizinhos, os amigos e a mulher. A expressão "até então" se refere a um prosaísmo que se rompe com um acontecimento marcante: o assassinato que tanto Mersault quanto Meursault cometem. Em La Mort Heureuse, esse assassinato é colocado logo no primeiro capítulo, em L'Étranger ele é transferido para o último capítulo da primeira parte, o que marcaria ainda mais essa estrutura binária na passagem da primeira para a segunda parte.

À primeira vista, essa divisão parece ter apenas uma importância estrutural para o texto: ao passar da divisão ternária para a binária, Camus renuncia a uma divisão clássica em que a terceira parte serviria como a síntese e a resolução das duas primeiras. No entanto, essa mudança se dá em um nível mais profundo relacionando-se ao tema do avesso e do direito, unindo o percurso narrativo ao percurso filosófico. Essa estrutura já havia sido apresentada em L'Envers et L'Endroit, no ensaio "La Mort dans l'âme". Nesse ensaio é narrada a experiência de duas viagens: a primeira se passa em Praga, na antiga Tchecoslováquia, e a segunda em Vicenza, na Itália. O texto se divide em duas partes descrevendo o avesso e o direito dessa experiência da viagem, que marcam não somente uma mudança de lugar, mas de tempo e estado do narrador, que passa de um sentimento de angústia a uma abertura para a alegria.

Em Praga, o narrador experimenta a angústia da falta de dinheiro e de não entender a língua do país. Mersault de La Mort Heureuse também viverá essa experiência de viagem a Praga no início da segunda parte da narrativa. ${ }^{169}$ Trata-se de uma experiência capital dentro do pensamento camusiano, pois o principal sentimento despertado pela viagem é o de se sentir estrangeiro $^{170} \mathrm{e}$, principalmente, sentir-se estrangeiro a si mesmo. Esse sentimento prefigura precisamente o absurdo: o homem separado de si mesmo e do mundo. A viagem funciona como

\footnotetext{
${ }^{169}$ Notar aqui os problemas do texto: Mersault vive a mesma angústia da falta de dinheiro vivida pelo narrador do ensaio, mas ele está rico por ter roubado a fortuna de Zagreus.

170 "Un grand désaccord se fait entre lui et les choses." (EE, 2007, p. 82) e "Ville dont je ne sais pas lire les enseignes, caracteres étranges où rien de familier ne s'accroche” (EE, 2007, p. 81).
} 
uma espécie de exílio, ${ }^{171}$ onde o homem se sente como o narrador de La Mort Heureuse, abandonado e só. Como vimos nos capítulos anteriores, o sentimento de exílio é fundamental para o absurdo.

Em L'Étranger, a viagem a Praga é suprimida, mas não o sentimento de estranheza gerado por ela. Como o viajante estrangeiro, Meursault vive todas as coisas como se fosse um observador exterior, como se não fizesse parte de seu julgamento. Ele sente-se alheio à própria sociedade a cujos signos ele não é familiar (por exemplo, o arrependimento de seu crime). Por fim, seu exílio será representado concretamente pelas paredes da prisão.

Há ainda uma correspondência entre o quarto de hotel em Praga, onde o narrador se encontra sozinho, reduzido a si mesmo e aos seus miseráveis pensamentos (EE, 2007, p. 79), e a própria solidão de Meursault encarcerado em sua cela: definitivamente ninguém pode imaginar o que são as noites na prisão (Et, 1996, p. 81). Nessa solidão, ambos são atormentados pela angústia da morte: o primeiro pela cena que presencia no hotel e o segundo em razão de sua sentença. O narrador do ensaio sente que a morte o persegue em cada rua, e os cheiros de Praga não fazem mais do que aumentar sua angústia. Ao caminhar pela cidade ele descreve a sensação de se sentir vazio, nauseado, ${ }^{172}$ sensação idêntica àquela que Meursault viverá na prisão (Et, 1996, p. 78). Essa náusea descrita pelos personagens é simbólica, em Le Mythe de Sysiphe ela se define por um mal-estar diante de nós mesmos e de outros homens, tornando-se um signo do absurdo (MS, 2008, p. 31).

A segunda parte do ensaio narra a experiência de alegria vivida nas planícies italianas: diferentemente de Praga, ali cada pessoa encontrada, cada cheiro é um pretexto para amar sem medidas (EE, 2007, p. 90). Mersault de La Mort Heureuse também viajará para a Itália, e experimenta em Gênova um sentimento de felicidade na comunhão com a natureza. Da mesma forma, a viagem é suprimida em L'Étranger; no entanto, o personagem vive essa mesma alegria ao desfrutar dos banhos de mar nas praias argelinas, na primeira parte da narrativa.

Podemos observar através desses apontamentos que o tema do avesso e do direito é fundamental para a escritura de L'Étranger, uma vez que a narrativa se divide entre uma experiência de comunhão com a natureza na primeira parte e uma experiência de distanciamento e separação na segunda. Dessa forma, a renúncia a uma estrutura ternária para a narrativa

\footnotetext{
171 “[...] essayant d'y retrouver une patrie, mais sortant plus vide et plus désespéré de ce tête-à-tête décevant avec moi-même." (EE, 2007, p. 80) e "Mersault se retrouvait sans patrie" (OC I, 2006, p. 1144).

172 "Et toujours cette pointe douloureuse en moi et le ventre serré." (EE, 2007, p. 78)
} 
relaciona-se com o avesso e o direito: duas partes que à primeira vista se contropõem, mas que se pensadas em relação a esse tema são inseparáveis e complementares, assim como o avesso e o direito de um tecido. ${ }^{173}$ Anos mais tarde, Camus escreverá que o sentido do livro se encontra exatamente no paralelismo das duas partes (C II, 1965, p. 30). Assim, podemos elaborar o seguinte esquema para L'étranger:

\begin{tabular}{|l|l|}
\hline PRIMEIRA PARTE & SEGUNDA PARTE \\
\hline Comunhão & Separação/Nostalgia da comunhão \\
\hline
\end{tabular}

Morte da mãe

Assassinato

Pena de morte

Indiferença

Absurdo

Lucidez

Na primeira parte, temos em primeiro lugar a morte da mãe e, em seguida, a descrição da comunhão com o mundo. No entanto, essa comunhão não é totalmente pura, visto que Meursault já percebe na natureza certa indiferença. Essa suposta comunhão é interrompida por outra morte, na qual o absurdo, revelado através da hostilidade da natureza, tem um papel fundamental. O assassinato rompe ao mesmo tempo com o equilíbrio do dia e com a felicidade [bonheur] que a comunhão entre o homem e o mundo geraria (Et, 1996, p. 61). "Desgraça" [malheur] é a última palavra do capítulo: como sabemos, esse conceito é fundamental para a tragédia grega. Nesse ponto, podemos estabelecer um pequeno paralelo entre a estrutura de L'Étranger e a estrutura clássica da tragédia. ${ }^{174}$ Nela, o herói é primeiramente apresentado como um sujeito no esplendor de sua vida, repentinamente um acontecimento altera bruscamente o seu destino e o conduz à desgraça. Esse momento foi nomeado por Aristóteles como "peripécia”, definida como uma mutação dos sucessos no seu contrário. Guardando as devidas ressalvas, é o que também ocorre

\footnotetext{
${ }^{173}$ Não podemos esquecer que a palavra "texto" deriva do vocábulo latino textum (tecido, entrelaçamento), do verbo textere (tecer, fazer tecido, entrançar, entrelaçar; construir sobrepondo ou entrelaçando). Em O Prazer do Texto, Barthes explicita essa relação: "Texto quer dizer Tecido" (2010, p. 74).

${ }^{174}$ Esse paralelo é válido, uma vez que Camus sempre afirmou sua predileção pela tragédia; em 1955 ele apresenta no Instituto francês de Atenas uma conferência intitulada "Sur l'avenir de la tragédie" que lhe permite reunir pontos de vista que ele já havia esposado em seus escritos anteriores. Porém, é preciso ressaltar que embora alguns elementos da tragédia sejam utilizados na narrativa, essa relação não é completa.
} 
com Meursault: muitos críticos, porém, falaram de uma tragédia solar, pois é o sol que precipita o personagem na desgraça.

Findada a primeira parte há uma elipse no texto que marcará a passagem abrupta de uma parte para outra: nada nos é narrado acerca da prisão de Meursault.

Na segunda parte, temos a experiência de separação com o mundo, experimentada tanto como um sentimento (a nostalgia da natureza) quanto fisicamente por Meursault (a prisão). A terceira morte, a do próprio Meursault, aparece no texto apenas como o anúncio de sua condenação. A consciência da morte, que chamamos no segundo capítulo de lucidez, se torna então a consciência da separação com o mundo. Se retomarmos a relação com a tragédia grega, esse é o momento que Aristóteles chamou na sua Poética de "reconhecimento", ou seja, a conversão da ignorância em conhecimento. Esse reconhecimento pode ser tanto de uma aliança (philia) quanto de uma hostilidade (ékhthra) entre as personagens.

Ao pensarmos na estrutura do texto, nos perguntamos se o tema do avesso e do direito também está presente em outros elementos da narrativa, como a linguagem ou a construção do personagem. 


\section{2. $O$ silêncio e o canto das palavras}

Em L'Étranger, o absurdo está presente em todos os planos da narrativa, ele é um tema, assim como se estende à própria estrutura. A linguagem está também permeada pelo absurdo e responde a uma regra de estética proposta por Le Mythe: a verdadeira obra de arte é aquela que diz menos (MS, 2008, p. 134). ${ }^{175}$ Ou seja, trata-se de uma recusa a uma expressão excessiva dos sentimentos, que levaria a uma linguagem destituída de floreios e ornamentos desnecessários. Em uma nota de 1933, Camus critica sua própria sensibilidade: ${ }^{176}$ "Seria preciso aprender a domar minha sensibilidade, sempre pronta para extravasar. Seria preciso que ela falasse, não que ela gritasse.". ${ }^{177}$

Porém, nos ensaios de L'Envers etL'Endroit e de Noces essa estética é deixada de lado quando se trata de cantar a natureza do Mediterrâneo: "Mar, campo, silêncio, perfumes desta terra, fartava-me de uma vida olorosa e mordia a polpa do fruto já dourado do mundo, perturbado por sentir seu sumo adocicado e espesso escorrendo pelos meus lábios."178 Nesses ensaios a sensibilidade se manifesta através da linguagem que por vezes beira o lirismo ao cantar as alegrias da comunhão com a natureza. Isso se dá porque é exatamente no mundo que o homem enxerga esse lirismo ${ }^{179}$ e essa espécie de canto. ${ }^{180}$

La Mort Heureuse também se distancia dessa estética ao sobrecarregar o texto com longas descrições e adjetivos, como neste exemplo: "Gerânios precoces e vermelhos entre aloés cinzentos, o azul do céu e os muros caiados, tudo era tão fresco e infantil que Mersault se deteve por um momento antes de retomar o caminho que descia da praça em direção à villa de

\footnotetext{
${ }^{175}$ Posição essa sustentada também nos Carnets (C I, 1962, p. 127).

${ }^{176}$ É necessário lembrar-se que, no ano de 1932, Camus escreve "Intuitions", escrito que fica no meio do caminho entre o poema em prosa e a narrativa. Podemos ler no último parágrafo: "Mais j'aime trop mes mensonges et mes attentes pour ne pas les crier avec ferveur. Où me tourner? Je ne sais qu'une chose: mon âme mystique qui brûle de se donner avec enthousiasme, avec foi, avec ferveur." (EJ, 1973, p. 197, grifo nosso).

177 "Il me faudrait apprendre à dompter ma sensibilité, trop prompte à déborder. [...] Il faudrait qu'elle parle, non qu'elle crie." (EJ, 1973, p. 201)

${ }^{178}$ (N, 1979, p. 17) "Mer, champagne, silence, parfums de cette terre, je m'emplissais d'une vie odorante et je mordais dans le fruit déjà doré du monde, bouleversé de sentir son jus sucré et fort couler le long de mes lèvres. (N, 2008, p. 21)

179 "L'évidence abstraite se retire devant le lyrisme des formes et des couleurs." (MS, 2008, p. 77)

180 "Et parvenu au terme de cette perspective sensible au cœur, j'embrassais d'un coup d'oeil cette fuite de collines toutes ensemble respirant et avec elle comme le chant de la terre entière." (N, 2008, p. 67)
} 
Zagreus." 181 Camus parece perceber sua infidelidade ao princípio de "dizer menos" quando escreve nos Carnets a propósito dessa narrativa: "Reduzir e Condensar", muito provavelmente uma tentativa de modificação do texto (C I, 1962, p. 66). O fato é que Camus não reescreve $L a$ Mort Heureuse, mas começa a escrever L'Étranger.

É somente com L'Étranger que essa estética de “dizer menos" se consolida através de sua relação com o absurdo, que, como vimos no segundo capítulo, nasce primordialmente do silêncio. A escritura de L'Étranger encarna assim um drama de expressão: o escritor só dispõe da linguagem para narrar a história desse homem taciturno e indiferente. ${ }^{182}$

O silêncio de Meursault e sua indiferença se expressarão por meio da própria linguagem do personagem e um plano acima na própria linguagem do texto, que foi nomeada por Barthes como uma escritura neutra (1972, p. 11). Ela se liga a uma espécie de língua básica que podemos relacionar ao telegrama que inicia a narrativa: frases curtas e sem relação de causalidade, elas comunicam o essencial sem deixar transparecer sentimentos. Esse será o estilo do restante da primeira parte da narrativa. A linguagem do personagem é também sustentada por frases curtas, por um vocabulário simples e uma sintaxe por vezes elementar. Podemos observá-la através dos diálogos que Meursault estabelece:

Je lui ai dit : «Comment ? » Il a répété en montrant le ciel : «Ça tape. » J'ai dit : «Oui. » Un peu après, il m'a demandé : «C'est votre mère qui est là ? » J'ai encore dit : «Oui. » «Elle était vieille ? J'ai répondu : «Comme ça », parce que je ne savais pas le chiffre exact. Ensuite, il s'est tu. (Et, 1996, p. 21) ${ }^{183}$

A essas e a muitas outras questões Meursault se contenta em dizer apenas "sim" ou "não", por não ter nada a acrescentar. Em suas relações íntimas o mesmo ocorre: com Marie os diálogos são lacônicos. Sobre a ideia de se casar com ela, ele se contenta em dizer apenas “sim”:

Elle a observe alors que le mariage était une chose grave. J'ai répondu : «Non. » Elle s'est tue un moment et elle m'a regardé en silence. Puis elle a parlé. Elle voulait simplement savoir si j'aurais accepté la même proposition venant d'une

\footnotetext{
181 (MF, 1997, p. 19) "De precoces géraniums rouges parmi des aloés gris, le bleu du ciel et le murs de clôture blanchis à la chaux, tout cela était si frais et si enfantin que Meursault s'arrêta un moment avant de reprendre le chemin qui de la place descendait vers la Villa de Zagreus." (OC, 2006, p. 1106)

${ }^{182}$ Lembremos que essa indiferença do personagem está ligada ao absurdo revelado tanto pelo silêncio da mãe quanto da natureza.

183 "Disse-lhe: - O quê? - Ele repetiu, apontando para o céu: - Está forte - Eu disse: - Sim. Pouco depois, perguntou-me: - É a sua mãe, quem ali vai? - Voltei a dizer: - Sim. - Era muito velha? - Respondi: - Assim, assim. - porque não sabia ao certo quantos anos tinha. O homem calou-se.” (Et, 1979, p. 170)
} 
autre femme, à qui je serais attaché de la même façon. J'ai dit : « Naturellement. » (Et, 1996, p. 47) ${ }^{184}$

Marie nota essa linguagem da indiferença ao afirmar que Meursault é um homem estranho. Podemos nos remeter a outro diálogo entre os dois, quando Marie diz que amaria conhecer Paris e lhe pergunta como é a cidade. Meursault, se utilizando de uma linguagem quase telegráfica, responde: "É suja. Há pombas e pátios escuros. As pessoas têm a pele branca.". ${ }^{85}$

Sartre relaciona esse trabalho do estilo com uma técnica nova. O crítico é o primeiro a estabelecer uma relação entre a escritura de Camus e a técnica do romance americano, principalmente com Hemingway: as mesmas frases curtas, onde cada uma recusa-se ao laço com a anterior, onde cada uma é um recomeço (1970, p. 50). Nas variantes de L’Étranger, podemos observar esse trabalho com a linguagem, quando, por exemplo, o escritor exclui uma conjunção:

Manuscrito I : Et j'ai pensé que je n'aurais pas dû... (QUILLIOT, 2000, p. 1919).

Versão final (parte I, capítulo I): Il n'a pas répondu.J'ai pensé alors que je n'aurais pas dû... (E, 2000, p. 1127).

Em resposta à crítica de Sartre, Camus afirma que utilizou a técnica americana em L'Étranger na medida em que ela convinha para descrever um homem sem consciência aparente, mas que, se esse procedimento é generalizado na narrativa, chegamos a um universo de autômatos, e esse não era seu objetivo (E, 2000, p. 1426). Meursault não é um autômato, ele raciocina, tem vontades, esboça até mesmo sentimentos, mas tudo isso se relaciona ao absurdo.

A partir desses breves apontamentos observamos o que muitos críticos chamaram de um estilo seco ou objetivo. Mas Barthes afirma também que esse estilo não é completamente seco, mas possui uma espécie de "ternura familiar" não se privando daquilo que poderia ser chamado de "irracional" do estilo (2004, p. 46). Esse estilo transparece sobretudo nos momentos em que Meursault se relaciona com a natureza, como no cortejo:

Je regardais la campagne autour de moi. À travers les lignes de cyprès qui menaient aux collines près du ciel, cette terre rousse et verte, ces maisons rares

\footnotetext{
184 "Maria observou que o casamento era uma coisa muito séria. Respondi: - Não. - Maria calou-se durante uns instantes e olhou-me em silêncio. Depois, falou. Queria simplesmente saber se, vinda de outra mulher com a qual estivesse relacionado do mesmo modo, eu teria aceito uma proposta semelhante. Respondi: - Possivelmente." (Et, 1979, p. 203)

${ }^{185}$ (Et, 1979, p. 204) “C'est sale. Il y a des pigeons et des cours noires. Les gens ont la peau blanche." (Et, 1996, p. 47)
} 
et bien dessinées, je comprenais maman. Le soir, dans ce pays, devait être comme une trêve mélancolique. (Et, 1996, p. 20) ${ }^{186}$

Nesses momentos, ele faz uso de uma linguagem mais poética, mais carregada de sentimentos, que muito se aproxima do lirismo de Noces. No cortejo, não é somente a morte que lhe interessa, mas também a paisagem. Do enterro, ele somente guarda a lembrança dos gerânios vermelhos nos jazigos do cemitério, e o corpo da mãe, que ele se recusara por duas vezes a ver, transforma-se poeticamente na terra cor de sangue que é atirada sobre seu caixão e na carne branca das raízes que ali se juntavam (Et, 1996, p. 22).

Para Sartre, quando Camus faz uso dessa linguagem, ele está sendo infiel à sua poética do absurdo. Mas essa concomitância entre uma linguagem da indiferença e o lirismo não significa infidelidade a uma poética. Trata-se, porém, do tema do avesso e do direito, do equilíbrio entre o pensamento e a linguagem em L'Étranger.

Essa poesia se manifesta principalmente depois que Meursault é preso: encerrado pelas paredes da prisão e tendo acesso apenas a uma pequena janela para o mundo, ele nota com a mesma sensibilidade de um poeta os jogos delicados de luz e sombra de um dia e as nuances do céu, nas palavras de Sarraute (1970, p. 58). Porém, não se trata mais de cantar a beleza do Mediterrâneo ou de falar de sua comunhão com a natureza. O que ele sente se assemelha ao sentimento do narrador de "La Mort dans l'âme": o desejo de retornar à comunhão com a natureza, um sentimento de nostalgia dessa relação que foi quebrada pelo absurdo. Nesses momentos, ele se revela por meio de palavras que vêm do coração e a prosa se torna poética:

Au début de ma détention, pourtant, ce qui a été le plus dur, c'est que j'avais des pensées d'homme libre. Par exemple, l'envie me prenait d'être sur une plage et de descendre vers la mer. A imaginer le bruit des premières vagues sous la plante de mes pieds, l'entrée du corps dans l'eau et la délivrance que j'y trouvais, je sentais tout d'un coup combien les murs de ma prison étaient rapprochés. (Et, 1996, p. $77)^{187}$

Meursault é um homem taciturno e fechado, mas não é um monstro de insensibilidade como afirma o procurador no julgamento. $\mathrm{Na}$ saída do tribunal ele relata com sensibilidade o

\footnotetext{
186 "Eu olhava os campos ao meu redor. Através das fileiras de cipestres que levavam às colinas perto do céu, desta terra ruiva e verde, destas casas raras e bem desenhadas, eu compreendia a minha mãe. A noite, neste sítio, devia ser como que um melancólico período de tréguas." (Et, 1979, p. 170)

187 "No início de minha detenção, no entanto, o mais duro foi virem-me a cabeça pensamentos de homem livre. Por exemplo, sentia de repente desejo de estar numa praia e de correr para o mar. Imaginando o barulho das primeiras ondas sob as plantas dos pés, a entrada do corpo na água, a libertação que era para mim o banho de mar, sentia de repente até que ponto as paredes da prisão me cercavam.” (Et, 1979, p. 244)
} 
quanto sente falta dos cheiros, das cores e dos barulhos de uma cidade que ele amava e na qual ele fora feliz:

En sortant du palais de justice pour monter dans la voiture, j'ai reconnu un court instant l'odeur et la couleur du soir d'été. Dans l'obscurité de ma prison roulante, j'ai retrouvé un à un, comme du fond de ma fatigue, tous les bruits familiers d'une ville que j'aimais et d'une certaine heure où il m'arrivait de mesentir content. Le cri des vendeurs de journaux dans l'air déjà détendu, les derniers oiseaux dans le square, l'appel des marchands de sandwiches, la plainte des tramways dans les hauts tournants de la ville et cette rumeur du ciel avant que la nuit bascule sur le port, tout cela recomposait pour moi un itinéraire d'aveugle, que je connaissais bien avant d'entrer en prison. (Et, 1996, p. 96$97)^{188}$

Aqui observamos a nostalgia de uma comunhão sensual com o mundo, mediada pelos sentidos, que se expressa poeticamente através de imagens.

Retomando a proposição inicial sobre a sensibilidade (que fale, mas não grite), concluímos que a linguagem de L'Étranger é uma tentativa de dar liberdade a todas as tonalidades dessa espécie de canto que é a escritura, canto habitado pela poesia das núpcias e pelo silêncio do absurdo: ritmo do avesso e do direito que só pode ser percebido no constraste entre o som e o silêncio.

188 "À saída do tribunal e ao subir para o carro, reconheci durante breves instantes o cheiro e o calor das tardes de verão. Na obscuridade da minha prisão rolante, reencontrei um a um, no fundo do meu cansaço, todos os ruídos familiares de uma cidade que eu amava e de uma certa hora em que tantas vezes me sentira contente. O pregão dos vendedores de jornais no ar já desoprimido, os últimos pássaros no largo, o grito dos vendedores de sanduíches, o lamento dos bondes nas pronunciadas curvas da cidade e este rumor do céu antes que a noite desça sobre o porto, tudo isto recompunha, para mim, um itinerário de cego, que eu conhecia muito antes de entrar na prisão." (Et, 1979, p. 268) 


\section{Meursault: obscuridade e claridade}

Muitos críticos já evidenciaram que a complexidade de Meursault se esconde sob uma aparente simplicidade. Se o observamos por um lado, encontraremos traços de uma personagem dita tradicional: ele possui um sobrenome, uma filiação, uma profissão, um passado (mesmo que pouco saibamos sobre ele) e um caráter. Por outro lado, se o observamos por esse mesmo caráter, afirmaremos que ele é um personagem estranho. Diferentemente de uma personagem tradicional, muitas vezes em busca da ascenção social ou da realização no amor, ele é alheio às convenções sociais como as relações familiares, o trabalho, a amizade e o amor. Em relação ao crime que comete ele é alheio ao arrependimento, seja ele civil ou cristão.

Meursault é um personagem absurdo, um estrangeiro: um homem separado do mundo, um exilado como nos descreve Le Mythe de Sisyphe (MS, 2008, p. 20). Em alguns momentos, ele revela-se até mesmo estranho a si mesmo. ${ }^{189}$ Em dado momento da narrativa, ele observa sua imagem no fundo de uma bacia de água e não reconhece aquele rosto sério que era refletido enquanto ele mesmo sorria. Esse estranhamento está relacionado com o sentimento despertado pelo absurdo: "Tanto quanto o estranho que, em certos instantes, vem ao nosso encontro num espelho, o irmão familiar e no entanto inquietante que encontramos nas nossas próprias fotos é também o absurdo." (MS, 2008, p. 29). ${ }^{190}$

Estrangeiro ao mundo e a si mesmo, Meursault é também estranho aos outros homens. Para o procurador ele é um homem sem alma, desprovido de qualquer princípio moral que guarda o coração humano (Et, 1996, p. 102). Isso também se relaciona ao absurdo, segundo o qual um homem é para nós sempre um desconhecido, um estranho, sempre haverá nele alguma coisa de irredutível que nos escapará, que não poderemos compreender (MS, 2008, p. 27).

Seguindo essa lógica, poderíamos conjecturar que uma narrativa em terceira pessoa seria o modo mais adequado para dar conta dessa impossibilidade de conhecimento, pois ela implicaria em um distanciamento, em uma mediação feita por um narrador.

De fato, a primeira tentativa de elaboração de uma narrativa se faz para Camus em terceira pessoa (La Mort Heureuse); no entanto, quando a reflexão sobre o absurdo toma forma e

\footnotetext{
189 "Étranger à moi-même et à ce monde", segundo a fórmula de Le Mythe de Sisyphe (MS, 2008, p. 38).

190 "De même l'étranger qui, à certaines secondes, vient à notre rencontre dans une glace, le frère familier et pourtant inquiétant que nous retrouvons dans nos propres photographies, c'est encore l'absurde.” (MS, 2008, p. 31)
} 
ele empreende a escritura de L'Étranger, ele substitui a terceira pela primeira pessoa. À primeira vista, essa mudança parece estar em contradição com o absurdo, pois a primeira pessoa indica geralmente uma maior transparência aos pensamentos e sentimentos do personagem. Mas não é o que ocorre; a ferramenta que poderia estar a serviço de uma transparência é, ao contrário, a causa da opacidade do personagem. Camus esclarece: "A narrativa em primeira pessoa que serve de costume a confidência foi colocada a serviço da objetividade em L'Étranger."(GRENIER, 2009, p. 110). Essa impossibilidade de seguir essa convenção da narrativa também pode ser explicada pelo absurdo: esse "je” não pode falar de si mesmo com profundidade, uma vez que esse coração que é o seu próprio será para sempre indefinível, para sempre o homem será estranho a si mesmo. ${ }^{191}$ Meursault parece lançar um olhar neutro sobre o mundo e sobre si mesmo. Genette, ao definir suas categorias de narrador, explica que Meursault é um tipo estranho de narrador intradiegético, que narra sua história em primeira pessoa, mas com uma espécie de focalização externa (GENETTE, 1983, p. 83).

Enquanto leitores esperaríamos poder ter acesso a certa interioridade desse "je" que narra a sua história, e essa expectativa é ainda maior, pois a primeira parte da narrativa se assemelha muito à escrita de um diário. Mas ao contrário do que se imagina, essa escrita não serve para desabafar, ${ }^{192}$ o que lemos ali é tão somente um inventário de fatos, uma observação da realidade que o circunda e as sensações que ele experimenta: calor, cansaço, tédio. Nunca um sentimento mais profundo se delineia. Não conhecemos seus pensamentos, temos acesso somente às descrições que ele faz do mundo e das pessoas que estão ao seu redor.

Esse tipo de caracterização do narrador causa certo estranhamento no leitor, pois se funda sobre o absurdo, cuja maior ambição não é explicar, mas descrever (MS, 2008, p. 131). Esse estranhamento pode ser experimentado em passagens do texto como no velório da mãe, em que Meursault descreve detalhadamente a enfermeira e os velhos do asilo, personagens aparentemente sem significação para a marcha da narrativa. Esse estranhamento é ainda maior na descrição da mulher autômato, que ele chega até mesmo a seguir pela rua, mas que esquece rapidamente.

\footnotetext{
191 "Entre la certitude que j'ai de mon existence et le contenu que j'essaie de donner à cette assurance le fosse ne sera jamais comblé." (MS, 2008, p. 36)

${ }^{192}$ Segundo Philippe Lejeune, uma das utilidades de manter um diário é desabafar, confidenciar, livrar-se de emoções sem constranger os outros. Ele escreve: "Decepções, raiva, melancolia, dúvidas, mas também esperanças e alegrias: o papel permite expressá-las pela primeira vez, com toda a liberdade.” (2008, p. 262).
} 
Assim, só podemos conhecê-lo através desse olhar sobre as coisas e principalmente através de suas próprias ações. Esse método de observação foi definido por Camus em Le Mythe de Sisyphe. Partindo do pressuposto de que o sentimento de absurdidade é incapturável, de que o conteúdo do coração de um homem nos é inacessível, a única maneira de aceder a esse absurdo é através da observação dos atos que deixam transparecer o estado de espírito que os supõe (MS, 2008, p. 27).

O método de análise filosófica que Camus engendra resulta, por um lado, em uma reflexão que se afasta do método metafísico ao apoiar-se na análise das consequências de um pensamento. Por outro lado, essa concepção não permite que o escritor crie para seu personagem uma psicologia profunda. Isso não significa que Meursault não disponha de uma psicologia, ele não é um títere. Ele é um homem tocado pelo absurdo que se deixa entrever através de seus atos. É por esse motivo que o próprio ato - e não as razões desse ato - se torna uma categoria central do tempo romanesco:

O que Camus nos propõe já não é um ato com ecos, um ato totalmente enviscado no estrato das causas, das justificações, das consequências e das durações: é um ato puro, inconsquente, separado de seus vizinhos, suficientemente sólido para manifestar uma submissão ao absurdo do mundo e suficientemente breve para fazer explodir a recusa e comprometer-se com ilusórias justificações desse absurdo. (BARTHES, 2004, p. 95)

O estranhamento se dá pelo fato de que existe uma separação entre as ações de Meursault e seus pensamentos. Essa separação é a própria consciência desse personagem narrador: ela funciona como uma parede envidraçada que deixa transparecer todos os gestos de uma pessoa, mas não o sentido deles. Esse efeito de transparência, escreve Sartre, permite que, enquanto leitores, vejamos tudo o que ele vê. Mas essa parede envidraçada foi construída de tal forma que ela é transparente às coisas, mas opaca às significações (SARTRE, 1970, p. 51).

Dessa maneira, o autor rompe com as classificações que definiriam as personagens como planas ou redondas. Essa classificação se define a partir da relação entre o grau de densidade psicológica que o personagem apresenta e suas ações: uma personagem plana apresenta uma linearidade entre a sua psicologia e seu fazer, por exemplo, uma personagem tipo. Enquanto uma personagem redonda, ou com tendência a sê-lo, caracteriza-se pela alinearidade entre a sua psicologia e seus fazeres, ou seja, é mais complexa. Meursault, porém, não se encaixa em nenhuma dessas categorias: entre seu fazer e seu ser, está o absurdo. Uma personagem dita redonda mataria movida por sentimentos como vingança, ódio, orgulho ou paixão, mas Meursault 
nem sabe mesmo porque cometeu esse ato e, consciente de seu ridículo, afirma que foi por causa do sol. O sol é assim promovido a uma metáfora do próprio absurdo. A psicologia de Meursault está assim baseada no próprio absurdo, o que nomeamos aqui de avesso da construção do personagem.

Para nós, leitores, Meursault é também um estrangeiro; e mesmo para os leitores familiarizados com a reflexão camusiana sobre o absurdo, o personagem guarda sua opacidade própria. Segundo a fórmula de Sartre, a leitura de L'Étranger é uma comunhão brusca de dois homens, o autor e o leitor, tendo entre eles o absurdo (SARTRE, 1970, p. 45).

No entanto, a indiferença de Meursault não deve ser confundida com apatia (CASTEX, 1970, p. 75) ou insensibilidade. Ao longo da leitura narrativa, podemos perceber, mesmo que por alguns instantes, seus sentimentos. Esses momentos estão, sobretudo, ligados à natureza, por exemplo, quando em uma mesma frase ele liga a temperatura da água do mar à sua alegria em poder nadar (Et, 1996, p. 54). Para Meursault, a verdadeira alegria só pode ser experimentada quando ele está em comunhão com o mundo. Em outro trecho, podemos ler: "Fazia muito calor e na saída do escritório gostei de passear lentamente ao longo do cais. O céu estava verde, eu me sentia contente.". ${ }^{193}$ Mais uma vez, a expressão de felicidade e contentamento está estritamente ligada à natureza. Particularmente a última frase chama a atenção, uma vez que a primeira oração (O céu estava verde) não está necessariamente ligada à segunda (eu me sentia contente). A conjunção que poderia expressar uma relação entre as duas foi suprimida, o que faz com que, dentro do encadeamento lógico do discurso, elas se equivalham. Assim, para o narrador, falar da natureza é falar do que sente, e vice-versa. Trata-se de fatos de mesma ordem: ele nota com agudeza os movimentos do céu, como se falasse das mudanças de seu coração.

Retomamos a ideia de que a primeira parte da narrativa seja uma espécie de diário, hipótese que pode ser corroborada por uma nota na última folha do manuscrito de La Mort Heureuse: "Faz no começo muitas coisas e em seguida abandona tudo. Não faz rigorosamente nada. Acompanha o tempo e sobretudo as estações (diário!).” (MF, 1997,p. 11). A forma do diário não será transposta explicitamente para nenhuma das duas narrativas, mas esse princípio se

\footnotetext{
193 (Et, 1979, p. 184) "Il faisait très chaud dans le bureau et le soir, en sortant, j'ai été heureux de revenir en marchant lentement le long des quais. Le ciel était vert, je me sentais content." (Et, 1996, p. 30)
} 
conserva em Meursault. ${ }^{194}$ Ao longo de toda a narrativa ele nota essas mudanças do céu ${ }^{195}$ e, na prisão, essa observação liga-se principalmente à passagem do tempo. ${ }^{196}$

Meursault é um personagem inteiramente submetido à natureza, e algumas vezes é ela própria quem lhe desperta os sentimentos: "Sentia-me um pouco perdido entre o céu azul e branco e a monotonia destas cores [...] Tudo isso, o sol, [...] me perturbava o olhar e as ideias." $" 197$.

Aqui o céu e o sol não somente agem sobre ele fisicamente, mas também psicologicamente. Essa submissão será central para a compreensão da passagem do assassinato, quando lhe parece que o céu se abre sob toda a sua extensão para deixar cair fogo sobre ele (Et, 1996, p. 62).

Podemos observar, assim, o quanto a construção do personagem está vinculada à natureza. Em alguns comentários posteriores à obra, Camus ligará a transparência de Meursault aos elementos naturais: no prefácio à edição americana ele escreve que Meursault é um homem pobre e nu, apaixonado pelo sol que não deixa sombras. Ou, ainda, em uma carta ele afirma que o personagem existe como uma pedra ou o vento ou o mar sob o sol, que não mentem jamais. ${ }^{198}$

Essa ligação de Meursault com a natureza se expresserá principalmente por sua presença física no mundo. Esse traço da caracterização do personagem guarda relações com a ideia de Núpcias. Para o narrador de "Noces à Tipasa" ver equivale a crer: ${ }^{199}$ "e não me obstino em negar aquilo que minha mão pode tocar e que meus lábios podem acariciar.". 200

\footnotetext{
${ }^{194}$ Camus nunca manteve um diário. No início de seus Carnets, ele se decide por fazer uma caderno sobre "le temps de chaque jour" (C I, 1962, p. 84). Nas notas seguintes, veremos esse trabalho se desenvolver. Observamos, dessa forma, que para Camus não são as mudanças de seu coração e sim as mudanças do clima e da natureza que lhe interessam registrar nessa escrita íntima dos cadernos.

${ }^{195}$ Alguns exemplos: "Le ciel était pleins de rougeurs"; "Le ciel était déjà plein de soleil"; "J'avais tout le ciel dans les yeux et il était beau et doré"; "Peu après, le ciel s'est assombri"; "Je suis longtemps resté à regarder le ciel"; "La journée a tourné encore un peu. Au-dessus des toits, le ciel est devenu rougeâtre".

${ }^{196}$ Alguns exemplos: "De celle-ci, lorsque je suis allongé, je vois le ciel et je ne vois que lui. Toutes mes journées se passent à regarder sur son visage le déclin des couleurs qui conduit le jour à la nuit."; "Je m'étendais, je regardais le ciel, je m'efforçais de m'y intéresser. Il devenait vert, c'était le soir."; "Maman disait souvent qu'on n'est jamais tout à fait malheureux. Je l'approuvais dans ma prison, quand le ciel se colorait et qu'un nouveau jour glissait dans ma cellule.".

${ }^{197}$ (Et, 1979, p. 171) "J'étais un peu perdu entre le ciel bleu et blanc et la monotonie de ces couleurs [...] Tout cela, le soleil, [...] me troublait le regard et les idées." (Et, 1996, p. 21)

${ }^{198}$ Carta citada por Bernard Pingaud (1992, p. 191).

${ }^{199}$ Aqui a relação física com o mundo é valorizada, o que implica uma desvalorização de tudo que está além disso; por esse motivo podemos observar o claro diálogo que o narrador estabelece com o vacabulário da religião cristã, cujo maior enfoque está não no corpo, mas no espírito. É nesse sentido que o narrador de "L'Envers et L'Endroit" afirma: "Tout mon royaume est ce monde" (2007, p. 17). Colocação essa que se relaciona com a referência bíblica: "Meu reino não é desse mundo" de João 18:36. O reino se situa aqui embaixo, entre os homens. Para Camus, trata-se de desfrutar do mundo, pois não há nenhuma transcendência possível: "Dans ces évangiles de pierre, de ciel et d'eau,
} 
Os sentidos têm, assim, um papel importante nos textos de Camus; não somente a visão ou o tato são enfatizados como meios de apreender o mundo, mas principalmente o olfato: em "La Mort dans l'âme" a apreensão da morte se traduz em termos de sensações, por exemplo, o cheiro de vinagre se transforma para o narrador em um cheiro de morte. Em Noces, o narrador fala de "cheiros de amor" que as alfarrobeiras ${ }^{201}$ espalham pela Argélia após a chuva: é exatamente esse cheiro que consagra as núpcias do homem e da terra (N, 2008, p. 50). Da mesma forma, os cheiros têm um papel importante em L'Étranger, eles são ao mesmo tempo signo do absurdo: o cheiro de gasolina somado às reverberações da estrada e do céu que fazem com que Meursault adormeça, o cheiro do couro, da graxa e do incenso que somados ao cansaço de uma noite de insônia confundem as suas ideias; quanto às núpcias: o cheiro de noite e de flores, o cheiro da terra molhada, o cheiro de sal dos cabelos de Marie, os cheiros do verão. O mesmo se passa com os ruídos: o barulho confortador da fonte confrontado ao barulho do tiro; os barulhos da cidade nas noites de verão e a angústia do barulho dos batimentos de seu coração na prisão.

Podemos concluir que o personagem foi construído a partir do tema do avesso e o direito, como no espaço de tempo que intermedeia o fim do dia e o início da noite: por um lado, o absurdo não permite que tenhamos acesso à sua interioridade, o que reforça sua obscuridade e seu estranhamento; por outro lado, as núpcias funcionam como uma espécie de claridade que, por meio da relação com a natureza, nos permite vislumbrar essa interioridade.

il est dit que rien ne ressuscite.” (N, 2008, p. 64). É por esse motivo que em Meursault essa relação física é valorizada e a morte não é temida. Para o narrador camusiano a morte só é odiada na medida em que interrompe essa relação com o mundo: "Ce doit être cela la jeunesse, ce dur tête-à-tête avec la mort, cette peur physique de l'animal qui aime le soleil." (N, 2008, p. 28).

200 "et je ne m'obstine pas à nier ce que ma main peut toucher et mes lèvres caresser." (N, 2008, p. 18)

${ }^{201}$ Árvore nativa do Mediterrâneo cultivada pela madeira e especialmente por seu fruto adocicado. 


\section{Natureza: beleza e indiferença}

Partindo do tema do avesso e do direito podemos compreender que a comunhão entre dois elementos, o mar e o sol, é central para a construção do personagem. Em algumas das notas preparatórias para La Mort Heureuse, Camus sublinha que em Mersault podemos ler "Mer" e "Soleil”, convidando a uma leitura simbólica de seu personagem (Dic, 2006, p. 544).

A comunhão desses dois elementos no nome do personagem identifica-o como um argelino, um homem do Mediterrâneo: "uma raça inteira, nascida do sol e do mar, cheia de vida e de encanto, que alcança a grandeza através de sua simplicidade e que, de pé nas praias, dirige um sorriso cúmplice ao sorriso deslumbrante de seus céus.". ${ }^{202}$ Nos ensaios de Noces, ela é sobretudo o signo de uma positividade: "este sol, este mar, meu coração saltando de juventude, meu corpo com sabor de sal e o imenso cenário onde a ternura e a glória se reencontram no amarelo e no azul.". ${ }^{203}$ É a partir dessa comunhão fundamental entre o sol e o mar que a praia se torna o espaço central de L'Étranger: ela é o espaço positivo dos banhos de Meursault e Marie, mas também o espaço negativo na cena da morte do árabe. Essa relação negativa entre mar e sol aparece já nos primeiros escritos de Camus, como em "La Maison Mauresque": "Minha angústia retornava à medida que eu observava essa mistura primordial entre a água e a luz, e não saberia dizer se era a água que envolvia a luz ou se a luz se afogava na água. Ainda o mal-estar diante do conflito desses dois elementos.". ${ }^{204}$ A natureza, representada pelo sol e pelo mar em L'Étranger, também possui o seu avesso e o seu direito, ela é signo tanto das núpcias quanto do absurdo, ela segreda tanto a beleza quanto a indiferença. ${ }^{205}$

202 (N, 1979, p. 17) "une race, née du soleil et de la mer, vivante et savoureuse, qui puise sa grandeur dans sa simplicité et debout sur les plages, adresse son sourire complice au sourire éclatant de ses ceils." (N, 2008, p. 21)

${ }^{203}$ (N, 1979, p. 13) "ce soleil, cette mer, mon coeur bondissant de jeunesse, mon corps au gout de sel et l'immense décor où la tendresse et la gloire se rencontrent dans le jaune et le bleu" (N, 2008, p. 17)

204 "Mon inquietude est alors revenue comme je regardais ce primordial mélange d'eau et de lumière dont on aurait dit si l'eau brassait la lumière ou si la lumière noyait l'eau. L'inquiétude devant, encore, le conflit de deux éléments. (EJ, 1973, p. 209)

205 "Une à une, derrière moi, les cigales enflent leur voix puis chantent : un mystère dans ce ciel d'où tombent l'indifférence et la beauté." (EE, 2007, p. 91) "Ce grand cri de pierre que Djémila jette entre les montagnes, le ciel et le silence, j'en sais bien la poésie : lucidité, indifférence, les vrais signes du désespoir ou de la beauté." (N, 2008, p. 32) 


\subsection{Os banhos de mar: prazer, mulher, comunhão}

Após o enterro de sua mãe, Meursault retorna ao trabalho. Seu escritório ficava no porto, de onde ele podia ver o mar e observar os cargueiros sob o sol escaldante. Depois do expediente, após um dia quente, Meursault se sentia feliz ao retornar para casa através do cais.

Mas eram os banhos de mar sob o sol que lhe traziam maior alegria. Nesses momentos a natureza aparece em toda a sua tranquilidade: o sol das quatro horas é agradável e a água está morna; no mar, pequenas ondas longas e preguiçosas (Et, 1996, p. 39). Essa tranquilidade dos elementos naturais reflete-se nos sentimentos do homem, como descreve o narrador de "Noces à Tipasa": ao avistar o mar calmo sob o qual o céu repousava sua ternura, ele sente uma alegria singular, que nasce de uma consciência tranquila (N, 2008, p. 20).

Para Meursault os banhos de mar são um símbolo de alegria e de comunhão com a natureza. O mesmo narrador de "Noces à Tipasa" descreve essa comunhão entre homem, mar e sol: "É preciso que eu fique nu e, depois, mergulhe no mar [...] Uma vez dentro d'água, é o sobressalto [...] o nado, os braços polidos de água, saídos do mar para se dourarem ao sol..”. 206

Em La Mort Heureuse, o banho de mar se torna um assunto entre Bernard e Mersault. Ele não compreende por que o médico escolhera a Argélia para se retirar já que ele nunca toma banhos de mar. O outro responde que é porque, para ele, amar a vida não é tomar banhos de mar, a natureza não pode de modo algum satisfazê-lo. Essa satisfação ele só pode encontrar nas mulheres (OC I, 2006, p. 1185).

Nesse ponto, é interessante notar que, para o homem camusiano, o prazer encontrado na comunhão entre mar e sol se estende e se liga à imagem da mulher e ao prazer proporcionado por ela, pois só existe um amor nesse mundo: "Estreitar um corpo de mulher é também reter de encontro a si essa alegria estranha que desce do céu para o mar.". ${ }^{207}$

Em L'Étranger, a beleza e a sensualidade de Marie são associadas a esses dois elementos: os seios firmes e seu bronzeado de sol lhe davam um aspecto de flor (Et, 1996, p. 39).

São também nos banhos de mar os momentos de maior intimidade entre Marie e Meursault (Et, 1996, p. 40).

\footnotetext{
${ }^{206}$ (N, 1979, p. 12) "Il me faut être nu et puis plonger dans la mer /.../ Entré dans l'eau, c'est le saisissement /.../ La nage, le bras vernis d'eau sortis de la mer pour se dorer dans le soleil." (N, 2008, p. 15)

${ }^{207}$ (N, 1979, p. 13) "Étreindre un corps de femme, c'est aussi retenir contre soi cette joie étrange qui descend du ciel vers la mer." (N, 2008, p. 16)
} 
Mulher e mar são imagens ligadas na mitologia grega por Afrodite, deusa da beleza, do amor e da procriação. Os mitos gregos sempre foram muito caros a Camus: em L'Étranger, podemos fazer uma associação entre Marie e Afrodite, já que ela aparece sempre ligada ao prazer dos banhos de mar. Podemos encontrar na narrativa uma cena que remeteria à imagem do nascimento de Afrodite no mar: "Estava viscosa da água salgada e tinha os cabelos caídos para trás.". ${ }^{208}$ Há também reminiscências ao nome da deusa que significa literalmente "espuma do mar". ${ }^{209}$ O banho de mar de Meursault e Marie é descrito como um momento de carinho e comunhão entre um homem e uma mulher. ${ }^{210}$

Nesse sentido, podemos compreender porque era indiferente a Meursault se casar oficialmente ou não com Marie, uma vez que as núpcias com a mulher estavam incluídas em suas núpcias com a natureza. Pelo mesmo motivo, o divórcio que separa Meursault da comunhão com a natureza e o conduz à prisão também o separa fisicamente de Marie. Esse fato marca a oposição que existe na narrativa entre a sociedade e a natureza, Meursault se sente muito mais à vontade entre os elementos naturais do que entre os códigos sociais.

\subsection{O sol: luz e morte}

O sol, como vimos, tem uma influência tanto boa quanto ruim sobre os sentimentos e as sensações de Meursault. No episódio da praia, ele desvia sua atenção da conversa com Raymond porque ele se ocupa em experimentar que o sol lhe fazia bem (Et, 1996, p. 54). Essa espécie de carícia do sol é contraposta à bofetada sentida por Meursault quando ele abre a janela e se depara com o dia ensolarado. Ainda na praia, ele é incapaz de pensar em qualquer coisa, pois o sol pesa sob a sua cabeça nua fazendo com que ele se sinta sonolento (Et, 1996, p. 56).

\footnotetext{
${ }^{208}$ (Et, 1979, p. 214) "Elle était toute visqueuse d'eau salée et elle tenait ses cheveux em arrière." (Et, 1996, p. 55)

209 "Marie m'a appris un jeu. Il fallait, en nageant, boire à la crête des vagues, accumuler dans sa bouche toute l'écume et se mettre ensuite sur le dos pour la projeter contre le ciel. Cela faisait alors une dentelle mousseuse qui disparaissait dans l'air ou me retombait en pluie tiède sur le visage." (Et, 1996, p. 39)

210 "Je l'ai aidée à monter sur une bouée et, dans ce mouvement, j'ai effleuré ses seins. J'étais encore dans l'eau quand elle était déjà à plat ventre sur la bouée. Elle s'est retournée vers moi. Elle avait les cheveux dans les yeux et elle riait. Je me suis hissé à côté d'elle sur la bouée. Il faisait bon et, comme en plaisantant, j'ai laissé aller ma tête en arrière et je l'ai posée sur son ventre. Elle n'a rien dit et je suis resté ainsi. J'avais tout le ciel dans les yeux et il était bleu et doré. Sous ma nuque, je sentais le ventre de Marie battre doucement. Nous sommes restés longtemps sur la bouée, à moitié endormis. Quand le soleil est devenu trop fort, elle a plongé et je l'ai suivie. Je l'ai rattrapée, j'ai passé ma main autour de sa taille et nous avons nagé ensemble." (Et, 1996, p. 23)
} 
O sol é assim uma das imagens mais recorrentes em L'Étranger. Como escreve Barthes (2004, p. 97), não há nenhum dos três episódios do romance (o enterro, a praia, o processo) que não seja dominado pela presença do sol, do calor e da luminosidade: L'Étranger é um "romance solar”. Mas não se trata de uma visão exótica, o sol em L'Étranger é parte constitutiva da obra, ele a permeia como permearia a vida de um argelino; ele é pano de fundo, quente, sensual e, muitas vezes, incômodo. Em pouco mais de 50 páginas ele é evocado cerca de 40 vezes na primeira parte da narrativa. Podemos estabelecer um paralelo entre a primeira parte de L'Étranger e o capítulo 3 da segunda parte de La Mort Heureuse, em que é narrado o episódio da Casa Diante do Mundo: são cerca de 15 páginas e 20 aparições do sol. Nesse lugar, a comunhão que se desfruta com a natureza é um sinônimo da própria felicidade. ${ }^{211}$ Catherine, a amiga de Mersault, sente o sol que escorre e demora-se sobre o seu rosto, e respira esse fogo que a invade. O narrador detalha a cena: ela desfruta do seu sol, suspira e geme (OC I, 2006, p. 1155).

Nos ensaios de L'Envers et L'Endroit e Noces, a imagem do sol guardará essas mesmas características, ligando-se ao prazer e à felicidade (N, 2008, p. 15), mas será principalmente o signo de uma comunhão com o mundo (EE, 2007, p. 116).

O sol é assim uma imagem movente: ele é um signo da felicidade e das núpcias com o mundo, mas é também um símbolo do absurdo.

Dentre todas as descrições que Camus faz do absurdo em Le Mythe de Sisyphe, ele escolhe justamente o sentimento que o homem tem de separação com o mundo para marcar a entrada no absurdo em L'Étranger. E ele escolhe a imagem do sol para selar essa entrada: o sol passa a ser um símbolo desse divórcio e o rompimento com a felicidade. Pois a felicidade é um prazer físico, significa ser livre e poder desfrutar do mundo.

Ao observarmos La Mort Heureuse e L'Étranger em perspectiva, podemos pensar que a imagem do sol evolui de uma imagem de felicidade para um signo do absurdo. Mas ao lermos os primeiros escritos de Camus, observaremos que a imagem do sol sempre conteve seu avesso e seu direito.

A primeira vez que a imagem do sol aparece nos escritos de Camus é no texto "La Maison Mauresque": "Nesse dia, eu consenti ao sol. Eu tive a intuição de sua virtude purificadora,

\footnotetext{
211 "Confiance et amitié, soleil et maisons blanches, nuances à peine entendues, là naissaient des bonheurs intacts dont il mesurait l'exacte réssonance. La Maison devant le Monde, disaient-ils entre eux, n'est pas une maison où l'on s'amuse mais une maison où l'on est heureux." (OC I, 2006, p. 1157)
} 
destruidora [...]". ${ }^{212}$ Nesse texto a imagem do sol é marcada por seu aspecto ambíguo: sua virtude é ao mesmo tempo purificadora e destruidora. Nessa passagem, o sol é ligado pela primeira vez à morte e ao sentimento de tragicidade. A expressão "consentir au soleil" também marca essa ambiguidade, pois pode significar tanto ligar-se ao sol, recebê-lo como uma oferta, quanto sujeitar-se a ele. Esse consentimento ao sol, que nesse texto ainda é uma intuição, se tornará uma convicção para a obra que está por vir. Essa expressão já indica a profunda ligação que os narradores camusianos terão com o sol. Como afirma Barthes, Meursault é um homem submetido ao sol em um sentido mais ou menos sacro, ele é uma experiência tão profunda do corpo que se torna um destino (BARTHES, 2004, p. 212).

Como sabemos, Meursault será, nos dois momentos cruciais de sua vida, testemunha ou vítima do que Lévi-Valensi chamou de estranha aliança entre sol e morte (2006, p. 105).

\subsubsection{A aliança morte/luz: o enterro}

A relação entre morte e natureza se dá desde os primeiros escritos de Camus, e se refere, sobretudo, à relação da imagem da morte representada pelo cemitério e a natureza ao seu redor. A visita a cemitérios sempre foi um tema recorrente nos escritos de Camus, mas ao contrário de representá-los de maneira melancólica ou sombria, eles aparecem sempre em relação à natureza. A luz do sol é a imagem mais empregada nessa aliança de morte/natureza. A primeira referência aparece em "La Maison Mauresque"; o cemitério é descrito sob o sol do meio-dia e o silêncio desse espaço tomado pela natureza onde todos estavam mortos sugeria ao narrador a indiferença (EJ, 1973, p. 212). Aqui o silêncio e a paz que a natureza propõem já são um signo de sua indiferença com relação à dor e a morte dos homens. Essa ideia será recuperada no ensaio "L'Envers et L'Endroit", dedicado totalmente à história de uma mulher que compra um túmulo: diante do sol e do calor; o narrador não quer refletir sobre o fato de que os homens morrem e sofrem, pois o que importa é a plenitude do céu que se derrama sobre a terra (EE, 2007, p. 117).

\footnotetext{
${ }^{212}$ En ce jour, je consentis au soleil. J'eus l'intuition de sa vertu purificatrice, destructrice des faux alanguissements et des rêveuses insignifiances. (EJ, 1973, p. 270)
} 
A segunda vez que a imagem do cemitério aparece é também em um texto de 1933: tratase de "Le Courage":

C'était une belle journée d'hiver, traversée de soleil. Dans ce bleu du ciel, on pouvait deviner le froid, tout pailleté de jaune. Le cimetière dominait la ville et on pouvait voir le beau soleil transparent tomber sur la baie tremblante de lumière comme une lèvre humide. Tout ça ne se concilie pas ? La belle vérité. $(\mathrm{EJ}, 1973, \text { p. 221) })^{213}$

Mais uma vez, temos a conjunção da imagem do cemitério banhado pelo sol. ${ }^{214} \mathrm{O}$ narrador se pergunta então se esses dois aspectos "mort/lumière" podem se conciliar. A resposta, como sabemos, Camus nos dará anos depois em L'Étranger.

Em “Devant la morte", também de 1933, a morte de uma personagem feminina, no caso a amada, é também confrontada ao mundo que permanece:

Les grands champs de vigne marchaient en rangs comptés. Les velours côtelé des terres s'aplatissait désespérément, sans un arbre pour gêner l'espace. Il faisait bon vivre dans l'air fluide et dilaté. Et il regarda devant lui, avec un peu d'ironie, le corps qui ne connaissait plus tout cela. (EJ, 1973, p. 230) (15 $^{215}$

Em La Mort Heureuse, porém, a descrição da morte da mãe não se relaciona com a descrição da natureza. Essa relação reaparecerá na descrição do velório e do enterro da mãe em L'Étranger:

Quand je suis sorti, le jour était complètement levé. Au-dessus des collines qui séparent Marengo de la mer, le ciel était plein de rougeurs. Et le vent qui passait au-dessus d'elles apportait ici une odeur de sel. C'était une belle journée qui se préparait. Il y avait longtemps que j'étais allé à la campagne et je sentais quel plaisir j'aurais pris à me promener s'il n'y avait pas eu maman. (Et, 1996, p. $17)^{216}$

\footnotetext{
213 "Era um belo dia de inverno com sol. No azul do céu, podia-se adivinhar o frio, coberto de amarelo. O cemitério dominava a cidade e podia-se ver o belo sol transparente sobre a baía trêmula como um lábio úmido. Tudo isso não se concilia? A bela verdade." (tradução nossa)

${ }^{214}$ Essa relação será recuperada em "L'Été à Alger": "Je ne connais pas d'endroit plus hideux que le cimetière du boulevard Bru, en face d'un des plus beaux paysages du monde. [...] Comment faire comprendre pourtant que ces images de la mort ne se séparent jamais de la vie ? Les valeurs ici sont étroitement liées.”.

215 "Os grandes campos de vinha se dividiam em fileiras. O veludo cotelê das terras nivelava-se sem nenhuma árvore para pertubar o espaço. Fazia bem experimentar o ar fluido e dilatado. E ele olhava com um pouco de ironia o corpo que não conhecia mais nada daquilo." (tradução nossa)

216 "Quando saí, o dia estava completamente levantado. Por cima das Colinas que separam Marengo do mar, o céu estava cheio de tonalidades de vermelho. E o vento, que passava por cima delas, trazia um cheiro de sal. Era um bonito dia que estava a preparar. Havia muito tempo que não vinha ao campo e teria tido imenso prazer em passear, se não fosse por mamãe.” (Et, 1979, p. 166)
} 
O narrador descreve um belo dia indiferente à morte de sua mãe. Essa indiferença é mais marcada ainda na aliança "mort/lumière" na medida em que o dia avança: "Hoje, o sol excessivo que fazia estremecer a paisagem tornava-a deprimente e inumana.". ${ }^{217}$ O sol que recai sobre a paisagem já é um primeiro signo do absurdo, tal como fora antecipado em "Amour de vivre": esse Nada que só pode nascer diante das paisagens arrasadas pelo sol (EE, 2007, p. 107). Ao longo do cortejo a luz e o calor do sol passam a recair sobre Meursault. Ele sente somente o sangue pulsar-lhe sobre a testa (Et, 1996, p. 22). A indiferença da natureza recai sobre Meursault e ele mesmo parece se tornar indiferente à morte da mãe. Mas essa indiferença em relação à morte da mãe relaciona-se com o fato de que tememos a morte na medida em que nos ligamos ao destino dos homens que vivem no lugar de contemplar o céu que dura, indiferente ao nosso sofrimento (N, 2008, p. 31). A tragicidade do mundo, para Camus, está no confronto entre a realidade sombria da finitude humana confrontada a beleza das paisagens argelinas cortadas pelo sol.

\subsubsection{A aliança luz/morte: o assassinato}

Não somente as imagens de morte na obra de Camus são habitadas pela natureza e pela luz do sol, mas o contrário também ocorre, as imagens de natureza e luz têm seu aspecto mortal. É por isso que muitas das meditações sobre a natureza em Noces acabam por uma reflexão sobre a morte. ${ }^{218}$ É esse gosto de morte que a paisagem da praia transmite a Meursault, através da indiferença da natureza. Ela é descrita por signos negativos: o sol cai sobre a praia, ele se quebra em pedaços sobre a areia e o mar e seu brilho é insustentável. Notemos que se trata da mesma descrição do enterro, da mesma maneira o sol lhe causa um mal-estar, ele pesa sobre a cabeça de Meursault, e as ondas trazem um pesado calor.(Et, 1996, p. 60). Meursault nota que esse sol era o mesmo daquele em que tinha enterrado a sua mãe.

A diferença entre essas duas cenas é que a primeira descreve uma cena de morte sob a indiferença do sol e da paisagem e na segunda é o próprio sol que ocupa o papel principal nessa morte.

${ }^{217}$ (Et, 1979, p. 170) "Aujourd'hui, le soleil débordant qui faisait tressaillir le paysage le rendait inhumain et déprimant." (Et, 1996, p. 20)

218 "Et je suivais tout au long de ce pays quelque chose qui n'était pas à moi, mais de lui, comme un goût de la mort qui nous était commun.” (N, 2008, p. 26) 
Meursault tenta fugir desse cenário de morte, mas em vão, pois uma praia inteira vibrante de sol comprime-o (Et, 1996, p. 61). Na cena final, sol e mar se aliam para que ele mate: "Foi então que tudo vacilou. O mar enviou-me um sopro espesso e fervente. Pareceu-me que o céu se abria em toda a sua extensão, deixando cair uma chuva de fogo.". ${ }^{219}$ Em "La Maison Mauresque" a aliança negativa entre mar e sol descrita em uma passagem do texto parece ecoar na cena de L'Étranger:

\begin{abstract}
Alors pas une ride n'assombrissait la mer et, en vérité, la moindre apparence de mouvement m'eût été insuportable. Cette extase que j'ai goûtée sous le soleil. Cette ivresse anéantie, cet étourdissement chalereux, cette plénitude, la bienfaisance de ce ciel qui déverse sans fin le torrent de sa lumière. (EJ, 1973, p. $216)^{220}$
\end{abstract}

Aqui o narrador também sofre a influência do mar e uma espécie de êxtase, um enebriamento diante do sol, um cegamento que no caso de Meursault o leva a matar.

Porém, a ligação entre luz e morte na cena de um assassinato aparece pela primeira vez no ensaio "La Mort dans l'âme". O narrador observa da porta de um quarto de hotel um homem morto sobre a cama e iluminado por uma luz e relata o mal-estar que essa mesma luz lhe causa: se tratava de uma luz de vida, uma luz que faz com que percebamos que estamos vivos, enquanto o homem estava morto (EE, 2007, p. 85).

Essa mesma ligação será retomada em La Mort Heureuse: a cena do assassinato se passa em um dia de sol resplandecente. Como Meursault na praia, Mersault sentia suas veias pulsarem na cabeça por causa do calor (OC I, 2006, p. 1106). O revólver com que ele vai matar Zagreus é descrito como uma arma reluzente pousada sob a carta que falaria de seu suposto suicídio. Encontramos um eco dessa imagem na faca que o árabe mostra para Meursault: "o árabe tirou a navalha do bolso e mostrou-ma ao sol. A luz refletiu-se no aço e era como uma longa lâmina faiscante que me atingisse a testa.". ${ }^{221}$ Essas duas cenas em que uma arma reluz não apontam somente o assassinato que está por acontecer, mas também a futura morte dos assassinos: em $L a$ Mort Heureuse, Mersault se torna um condenado à morte por causa de uma doença que contrai

\footnotetext{
${ }^{219}$ (Et, 1979, p. 223) “C'est alors que tout a vacillé. La mer a charrié un soufflé épais et ardent. Il m’a semblé que le ciel s'ouvrait sur toute son étendue pour laisser pleuvoir du feu." (Et, 1996, p. 62)

220 "Nenhuma ruga agitava o mar, na verdade, a mínima aparência de movimento me teria sido insuportável. Esse êxtase que eu experimentei sob o sol, esse enebriamento arrasador, esse atordoamento ardente, essa plenitude, essa benevolência do sol que derrama infinitamente a torrente de sua luz." (tradução nossa)

${ }^{221}$ (Et, 1979, p. 223) "l'Arabe a tire son couteau qu'il m'a presenté dans le soleil. La lumière a glicé sur l'acier et c'était comme une longue lame etincellante qui m'atteignait au front." (Et, 1996, p. 61)
} 
nesse mesmo dia. Em L'étranger, a luz do sol sob a lâmina da faca aponta a lâmina da guilhotina que vai cortar a cabeça de Meursault.

\subsubsection{A aliança morte/luz: a condenação à morte}

Ao longo de todo esse capítulo observamos o quanto a estrutura do avesso e o direito, das núpcias e o absurdo, da luz e da morte, foi fundamental para a estrutura de L'Étranger. Como na arquitetura da casa árabe, a narrativa tira sua beleza desse amálgama: assim como entre os cômodos da casa, o sol entra por todas as frestas da narrativa, mas há também os momentos de penumbra dados pela morte.

Retomando a definição empregada por Camus, a obra se baseia em uma espécie de ritmo binário em que se sucedem tempos fortes e fracos que se alternam com intervalos regulares como em um verso musical.

Em toda a primeira parte há uma unidade de tom na descrição da vida prosaica de Meursault: essa narrativa acinzentada só é rompida pela "música confusa do calor e do sol” (EJ, 1973, p. 217) que recai sobre sua cabeça como um címbalo na cena do assassinato. A história se interrompe e o reencontramos preso (Et, 1996, p. 61) na segunda parte: o que se segue é a narrativa dos episódios rotineiros da instrução e do processo; como no episódio do velório da mãe, o sol entra por todas as frestas e o calor é insuportável. Até sua condenação à morte: é nesse momento que o tom se eleva mais uma vez e ele acede "à verdade que é aquela do sol e que será também a da sua morte." (EE, 2007, p. 16). Mas o sol não mais aparecerá aqui como nas outras partes, a aliança entre morte e luz é simbólica: no momento em que é condenado à morte, Meursault passa todas as noites aguardando o momento do nascimento das primeiras luzes do dia (Et, 1996, p. 113), quando viriam buscá-lo. Aqui, morte e luz se conjugam e resultam em lucidez, ${ }^{222}$ como nos lembra o narrador de L'Envers et L'Endroit: é preciso manter os olhos abertos para a luz e para a morte. Essa aliança permite a Meursault a revelação de uma verdade: a aceitação consciente da morte e a abertura para a terna indiferença do mundo.

\footnotetext{
${ }^{222}$ Podemos ligar etimologicamente luz e lucidez, ambas têm sua raiz no vocábulo latino lux/lucis.
} 


\section{A terna indiferença de $L$ 'Étranger}

Para analisarmos a estrutura final de L'Étranger nos remetemos mais uma vez ao ensaio "La Mort dans l'âme": os personagens das duas narrativas convivem com a morte na alma. ${ }^{223} \mathrm{O}$ primeiro não consegue se desvencilhar da cena de morte que presenciou no hotel e o segundo está plenamente consciente de que vai morrer.

Mas o principal sentimento compartilhado pelo narrador do ensaio e Meursault é a nostalgia. Para o primeiro trata-se de um desejo de retornar à terra natal, enquanto para o segundo trata-se da nostalgia de um tempo de liberdade e de fruição da natureza. Ambos se encontram em um mundo fechado e estão distantes de sua pátria, que, nos dois casos, é o Mediterrâneo. Esse sentimento já havia sido apresentado em "La Maison Mauresque": utilizando-se repetidamente da fórmula "Eu me lembro" o narrador se lembra dos momentos vividos sob o transbordante sol do verão argelino, das pequenas cidades à beira-mar, onde ele tentava compreender a perfeição contemplando a água em seu azul absoluto e o céu branco de calor (EJ, 1973, p. 216).

Ao caminhar por Praga, o narrador do ensaio pensa desesperadamente em sua cidade às margens do Mediterrâneo, nas doces noites de verão com suas luzes verdes repletas de moças jovens e belas. ${ }^{224}$ Meursault também se lembra desse tempo de comunhão com o mundo, mas seu distanciamento não é dado pela viagem, mas pela prisão:

J'ai été assailli des souvenirs d'une vie qui ne m'appartenait plus, mais où j'avais trouvé les plus pauvres et les plus tenaces de mes joies: des odeurs d'été, le quartier que j'aimais, un certain ciel du soir, le rire et les robes de Marie. (Et, 1996, p. 105) 225

Da mesma maneira, no último capítulo de La Mort Heureuse, Mersault não pode desfrutar da natureza, pois está doente e trancado em seu quarto:

Il pensait à ces soirs sur Alger où monte dans le ciel vert le bruit des hommes sortant des fabriques à l'appel des sirenes. Entre le goût des absinthes, les fleurs sauvages parmi les ruines et la solitude des petites maisons entourées de cyprès

\footnotetext{
${ }^{223}$ Na língua francesa a expressão "La Mort dans l'âme" também significa "estar desesperado".

${ }^{224}$ Entre esses dois, encontramos Mersault de La Mort Heureuse, que também vive essa angústia em Praga: "Une ferveur ardente et secrète se gonflait en lui avec des larmes et c'était une nostalgie de villes pleines de soleil et de femmes, avec des soirs verts qui ferment les blessures." (CAMUS, 2006, p. 1147).

225 "Assaltaram-me as recordações de uma vida que já não me pertencia, mas onde encontrara as mais pobres e as mais tenazes das minhas alegrias: odores de verão, do bairro que eu amava, um certo céu ao anoitecer, o riso e os vestidos de Maria.” (Et, 1979, p. 277)
} 
dans le Sahel se tissait l'image d'une vie où la beauté et le bonheur prenaient son visage de désespoir et où Patrice trouvait une sorte d'éternité fugitive. (OC I, 2010, p. 1193$)^{226}$

Ao descrever a paisagem da qual ele sente falta, Mersault percebe que mesmo essa imagem de beleza e felicidade está permeada de desespero.

Para o narrador do ensaio, essa nostalgia só se apazigua no momento em que ele deixa a Europa Central e se dirige para o Mediterrâneo; mas, mesmo estando diante dessa paisagem iluminada das planícies italianas, ele sente que aquela angústia ainda o acompanha (EE, 2007, p. 94). Essa angústia só é dissipada quando o narrador confronta o seu desespero à indiferença secreta de uma das mais belas paisagens do mundo (EE, 2007, p. 94). Ele compreende que essas duas experiências aparentemente excludentes, a de Praga e a da Itália, lhes são caras: ele não consegue separar seu amor pela luz de sua secreta ligação com a morte (EE, 2007, p. 95). Essa compreensão também se dará para Mersault, que percebe uma mesma felicidade na vida e na morte. $^{227}$

Da mesma maneira, em L'Étranger, a nostalgia de um momento de liberdade e de comunhão com a natureza só é apaziguada em Meursault quando ele se abre para a terna indiferença do mundo (MS, 2008, p. 46). Diante de sua condenação à morte, Meursault percebe, como o narrador de 'La Mort dans l'âme', que a comunhão que ele pensava ter estabelecido com a natureza sempre fora habitada ao mesmo tempo pela beleza e pela indiferença:

Je crois que j'ai dormi parce que je me suis réveillé avec des étoiles sur le visage. Des bruits de campagne montaient jusqu'à moi. Des odeurs de nuit, de terre et de sel rafraîchissaient mes tempes. La merveilleuse paix de cet été endormi entrait en moi comme une marée. À ce moment, et à la limite de la nuit, des sirènes ont hurlé. Elles annonçaient des départs pour un monde qui maintenant m'était à jamais indifférent. (Et, 1996, p. 121)

\footnotetext{
226 "Pensava nas tardes de Argel, onde sobe ao céu verde o ruído dos homens que saem das fábricas quando soa o apito. Entre o gosto do absinto, as flores selvagens em meio à ruína e a solidão das casinhas cercadas de ciprestes no deserto de Sahel, tecia-se a imagem de uma vida em que a beleza e a felicidade assumiam um ar de desespero e em que Patrice encontrava uma espécie de eternidade fugidia." (MF, 1997, p. 133)

227 "Là était tout son bonheur de vivre et de mourir." (OC I, 2010, p. 1194)

228 "Julgo que dormi, pois acordei com estrelas sobre o resto. Subiam até mim ruídos campesinos. Aromas de noite, de terra e de sol refrescaram-me as têmporas. A paz maravilhosa deste verão adormecido entrava em mim como uma maré. Neste momento, e no limite da noite, soaram apitos. Anunciavam possivelmente partidas para um mundo que me era para sempre indiferente." (Et, 1979, p. 297)
} 
Podemos notar que os barulhos e os cheiros ligados à natureza estão presentes nesse momento, como sempre estiveram presentes na vida de Meursault. Nessa poética do avesso e do direito o personagem se recusa a escolher entre o amor de viver e o desespero de viver, o que o conduz a uma aceitação lúcida da beleza e da indiferença do mundo. Essa aceitação e essa consciência conduzem o homem à felicidade, felicidade esta que será sempre habitada pelo seu avesso; em um texto de juventude podemos ler: "E quando tudo desmorona, recomeçamos, simples, ainda mais ricos de dor, quase felizes do sentimento de nossa desgraça." (EJ, 1973, p. 201, tradução nossa).

Como vimos anteriormente, esse é o momento fundamental da tragédia, o momento do reconhecimento tanto de uma philia (aliança) ou de uma ékthra (hostilidade) entre os personagens: porém, no interior do tema do avesso e do direito, Meursault reconhece que sua relação com o mundo se define tanto por uma philia (núpcias) quanto por uma ékthra (absurdo). Assim, no desfecho da narrativa, o avesso e o direito estão unidos, e é dessa maneira que o ciclo que se iniciou pelo menos dez anos antes pode findar: na consciência do absurdo que a união entre o homem e o mundo sempre pressupôs. É nessa comunhão lúcida com o mundo é que Meursault sente que havia sido feliz e que ainda o era.

Dessa forma, podemos observar que o avesso e o direito se encontram em L'Étranger tanto estruturalmente quanto tematicamente. Nessa narrativa, Camus também se recusou a escolher entre esses opostos. Na conclusão de L'Étranger, também se juntam o percurso narrativo e o percurso filosófico de Camus, formando o que chamamos nesta dissertação de o avesso e o direito da escritura camusiana. 


\section{CONSIDERAÇÕES FINAIS}

\section{Tudo isso não se concilia?}

A análise dos textos de Camus em perspectiva, de L’Étranger aos Écrits de Jeunesse, retoma a pergunta que o narrador de "L'Ironie" se coloca ao narrar três histórias aparentemente desligadas: "Tout ça ne se concilie pas?” (EE, 2007, p. 52). Essa questão é fundamental para nossa análise, uma vez que esses textos possuem formas muito diferentes: escritos curtos, narrativas, ensaios tanto literários quanto filosóficos. Essa conciliação entre alguns desses textos, como vimos, se dava através do que Camus chamava de ciclo do absurdo. Mas, como questionamos em nosso primeiro capítulo, todos os textos anteriores a L'Étranger, especialmente os publicados, não eram incluídos em nenhum ciclo. Como conciliar esses escritos anteriores a 1942 ao que vem depois? Ou melhor, no lugar de pensarmos em uma conciliação, deveríamos pensar antes em um processo de ruptura?

De fato, essa fase que vai de 1932 até a publicação de L'Étranger é um período de experimentação em todos os sentidos, principalmente na forma e na linguagem dos textos. Mas nossa preocupação não estava no fato de que houvesse rupturas de um texto para outro, mas de que a continuidade era um traço fundamental entre eles. Uma continuidade principalmente de natureza temática: olhando para esses escritos anteriores também podíamos observar ali o absurdo. Não somente o absurdo, mas também a noção de núpcias. Assim, esse olhar em perspectiva nos fez perceber que absurdo e núpcias sempre estiveram presentes nos escritos camusianos dessa fase e que, principalmente, o absurdo não era o único tema presente em L'Étranger.

Todos esses escritos anteriores formavam assim um grande ciclo, cuja expressão já havia se dado com a publicação da reunião de ensaios L'Envers et L'Endroit, que se utilizava desses escritos para sua composição ao mesmo tempo em que conjugava as duas noções fundamentais do pensamento camusiano, que chamamos de o avesso e o direito. Dessa forma, conjecturamos que poderia haver um grande ciclo do avesso e do direito, uma vez que não podemos dividir os 
escritos de Camus entre um primeiro ciclo das núpcias e um ciclo do absurdo, pois eles se entrelaçam.

Ao pensarmos no avesso e no direito, percebemos que as núpcias e o absurdo eram temas que, ao perpassarem os textos, se direcionavam ao mesmo tempo tanto à reflexão filosófica quanto à literária. Os ensaios de L'Envers et L'Endroit nos ofereceram uma espécie de modelo, no qual avesso e direito, filosofia e literatura se uniram, nos auxiliando a compreender como esse tema tanto filosófico quanto literário foi central para a escritura de L'Étranger. O avesso e o direito era enfim, a conciliação, a unidade que se ignorava entre os escritos. No entanto, ao se direcionar para a composição de textos de natureza diversa, esse tema ia sofrendo algumas alterações e tomando contornos diferentes, formando o que chamamos de um movimento em espiral no qual um mesmo tema se aproxima dos textos anteriores ao mesmo tempo em que deles se distancia.

Concluímos que um dos aspectos do processo de criação camusiano no período de 1932 a 1942 é a circulação de um mesmo tema (e todos os subtemas ligados a ele) no qual se une tanto o percurso filosófico quanto o percurso literário de Camus. Assim, o avesso e o direito é tanto uma realidade observada no mundo quanto uma forma como o escritor pode conceber o seu trabalho: literatura e filosofia formam o avesso e o direito dessa moeda chamada escritura.

Porém, quando olhamos para o período posterior a esse, chamado de ciclo da revolta, podemos perceber que esse processo se repete: o absurdo é retomado no ciclo da revolta, ${ }^{229}$ assim como a revolta já aparecia no ciclo do absurdo. ${ }^{230}$ Esse movimento pode ser observado na narrativa do ciclo seguinte, onde também os mesmos temas perpassam tanto o ensaio filosófico (L’Homme Révolté) como a narrativa (La Peste):

\footnotetext{
229 "Je crie que je ne crois à rien et que tout est absurde, mais je ne puis douter de mon cri et il me faut au moins croire à ma protestation. La première et la seule évidence qui me soit ainsi donnée, à l'intérieur de l'expérience absurde, est la révolte. [...] La révolte naît du spectacle de la déraison, devant une condition injuste et incompréhensible. Mais son élan aveugle revendique l'ordre au milieu du chaos et l'unité au cœur même de ce qui fuit et disparaît. Elle crie, elle exige, elle veut que le scandale cesse et que se fixe enfin ce qui jusqu'ici s'écrivait sans trêve sur la mer. Son souci est de transformer. Mais transformer, c'est agir, et agir, demain, sera tuer, alors qu'elle ne sait pas si le meurtre est légitime." (E, 1965, p. 419)

${ }^{230}$ Em Le Mythe de Sisyphe, a revolta é colocada ao lado da liberdade e da paixão como uma consequência do absurdo: "uma das poucas posturas filosóficas coerentes é a revolta, o confronto perpétuo do homem com sua própria escuridão." (MS, 2008, p. 66). Camus propõe três respostas para o absurdo: o suicídio, a esperança e a revolta, sendo que somente a última é aceita por Camus apontando para L'Homme Révolté.
} 
En attendant, voici le premier progrès que l'esprit de révolte fait faire à une réflexion d'abord pénétrée de l'absurdité et de l'apparente stérilité du monde. Dans l'expérience absurde, la souffrance est individuelle. À partir du mouvement de révolte, elle a conscience d'être collective, elle est l'aventure de tous. Le premier progrès d'un esprit saisi d'étrangeté est donc de reconnaître qu'il partage cette étrangeté avec tous les hommes et que la réalité humaine, dans sa totalité, souffre de cette distance par rapport à soi et au monde. Le mal qui éprouvait un seul homme devient peste collective. Dans l'épreuve quotidienne qui est la nôtre, la révolte joue le même rôle que le «cogito » dans l'ordre de la pensée : elle est la première évidence. Mais cette évidence tire l'individu de sa solitude. Elle est un lieu commun qui fonde sur tous les hommes la première valeur. Je me révolte, donc nous sommes. (HR, 1951, p. 36) 231

Nessa passagem do ensaio, Camus explicita que a experiência do absurdo é individual, mas ao desenbocar no sentimento de revolta, o mal que somente um homem experimentava passa a ser peste coletiva. Assim, não há somente uma ligação entre Le Mythe e L'homme révolté, mas também entre a experiência individual de Meursault em L'Étranger e La Peste, onde o absurdo e a revolta serão experimentados pelos moradores de toda uma cidade. Por incluir ao mesmo tempo o tema do absurdo e da revolta, alguns críticos encararam La Peste como um romance de transição entre os dois ciclos.

No entanto, sob o aspecto do processo de criação camusiano, percebemos que todos os textos de Camus estão interligados e, seguindo o movimento em espiral, eles apontam ao mesmo tempo para o que estava antes e o que veio depois. Assim, de acordo com nossa proposta de análise, o tema das núpcias se incluía no ciclo do absurdo, assim como o tema do absurdo se inclui no ciclo da revolta, e o contrário também é verdadeiro. Podemos falar assim de um processo de criação mais amplo: não há em toda a obra de Camus um livro que não estabeleça relação, mesmo que sutil, com outros textos. ${ }^{232}$ Perguntado certa vez se daria uma continuação a L'Homme Révolté, Camus responde que a obra de certos escritores forma um todo onde cada uma é esclarecida pela outra, onde todas se concernem (E, 2000, p. 745).

\footnotetext{
231 "Enquanto isso, eis o primeiro progresso que o espírito de revolta provoca numa reflexão inicialmente permeada pelo absurdo e pela aparente esterelidade do mundo. Na experiência do absurdo, o sofrimento é individual. A partir do movimento de revolta, ele ganha a consciência de ser coletivo, é a aventura de todos. O primeiro avanço da mente que se sente estranha é, portanto, reconhecer que ela compartilha esse sentimento com todos os homens, e que a realidade humana, em sua totalidade, sofre com esse distanciamento em relação a si mesma e ao mundo. O mal que apenas um homem sentia torna-se peste coletiva. Na nossa provação diária, a revolta desempenha o mesmo papel que o cogito na ordem do pensamento: ela é a primeira evidência. Mas essa evidência tira o indivíduo de sua solidão. Ela é um território comum que fundamenta o primeiro valor dos homens. Eu me revolto, logo existimos" (HR, 1996, p. 35)

${ }^{232}$ Vide o uso que Camus faz da anedota de Le Malentendu em L'Étranger (“A história da Tchecoslováquia”) e a referência ao julgamento de um homem que matara um árabe em La Peste.
} 
Dessa forma, nossa proposta de análise retomou também a resposta que o narrador de "L'Ironie" oferece à questão que evocamos no início: "La mort pour tous, mais à chacun sa mort.". Assim como a morte é o tema que une histórias tão diferentes em "L'Ironie", um mesmo tema percorre todos esses escritos, mas, para cada texto, uma forma diferente.

Essa é também a ideia que norteou nosso segundo capítulo: uma vez que é a morte é também um tema fundamental dentro do avesso e o direito, ela é tanto o signo de ruptura com o mundo quanto o da reconciliação lúcida. A morte aparece assim como o tema que se faz presente em todos os textos, pois é fundamental para o percurso filosófico de Camus. Em L'Envers et L'Endroit e em Noces, é ela que interrompe as núpcias com a terra, por isso mesmo ela é fundamental para a consciência do absurdo. A morte apareceu nesses textos através dos temas do enterro, do assassinato, da velhice, da doença e por fim da pena de morte, mas todos apontavam para algo mais simbólico, a condição de condenado à morte a que todos os homens estão fadados. Por esse motivo, em L'Étranger esse tema toma tanto contornos literários quanto filosóficos: a morte da mãe e a morte do árabe apontam para a condenação de Meursault, que aponta, por fim, para a própria condição humana.

No entanto, pensando ainda no aspecto filosófico, não abordamos em nossa análise o tema do suicídio, pois, como lemos em Le Mythe de Sisyphe, uma vez consciente do absurdo o homem possui duas escolhas: manter a consciência ou suicidar-se. A argumentação do ensaio terá justamente como tema central a recusa da morte enquanto suicídio, uma vez que ele se configura como uma fuga ao absurdo e não como uma solução.

Esse tema não aparece explicitamente em L'Étranger, mas foi tema fundamental para $L a$ Mort Heureuse: a primeira formulação da narrativa previra o suicídio de Patrice após a narrativa de seu passado doloroso. Mas, como afirma Abou, a narrativa sofre uma reviravolta temática e a liberdade que seria encontrada no suicídio o personagem encontra no assassinato (OC I, 2010, p. 1449). Assassinato que ele camufla em suicídio. Assassinato e suicídio são temas que reaparecem nas obras teatrais ligadas ao ciclo do absurdo: em Le Malentendu, Martha assassina o próprio irmão com a ajuda da mãe sem o saber e, após a descoberta da identidade do homem, são as assassinas que se suicidam. Como em L'Étranger, a morte de um personagem aponta para a morte do outro e o mal-entendido sela a tragédia. Em Caligula, o imperador romano é confrontado com a morte de sua irmã e amante Drusila e compreende que todo o seu poder não 
lhe serve ante a inevitabilidade da morte: como não pode vencê-la, Caligula decide encarnar o próprio destino e matar os homens.

Le Malentendu e Caligula retomam diversos aspectos já abordados em todos os escritos anteriores: a principal relação que podemos estabelecer com L'Étranger é a partir do tema do luto. A maneira como Caligula lida com o luto em relação à morte de sua irmã e amante é o que vai gerar a morte de outros homens e finalmente a sua própria morte. Em Le Malentendu, é o sentimento que a mãe possui em relação ao assassinato do filho que gera a sua morte, que por sua vez gera a morte da filha. Assim, vemos que a morte enquanto tema que se liga tanto ao avesso quanto ao direito é também o tema que unifica esse ciclo de obras que Camus chamou de absurdo.

Assim, podemos observar como um mesmo tema percorre a reflexão filosófica de Camus e a escritura de sua narrativa. A morte, como vimos, é também o tema que move a escritura de Meursault: ela é ao mesmo tempo a sombra de uma realidade desesperadora e a luz/lucidez que ilumina o homem em seu apego e seu amor à vida.

Essa realidade trágica do mundo rege também a escritura; é nesse sentido que observamos em L'Étranger que o tema do avesso e do direito aparece como uma estrutura, ou seja, ele está intrincado no processo de elaboração da narrativa, ele é o fil rouge que a sustenta.

Em primeiro lugar, esse tema aparece na estrutura que se divide em duas partes que se findam por uma morte, retomando o movimento do avesso e o direito que analisamos no segundo capítulo. O narrador experimenta a comunhão com o mundo que é interrompida por uma morte, e é a sua própria morte que lhe dá a consciência de que sua relação com o mundo é permeada pelo absurdo. Essa estrutura, como vimos, foi utilizada no ensaio "La Mort dans l'âme", de L'Envers et L'Endroit.

Essa estrutura também pode ser observada na linguagem, a possibilidade de expressão está intimamente ligada ao tema do avesso e o direito. Camus utiliza-se ao mesmo tempo do silêncio do absurdo e da poesia das núpcias, equilibrando pensamento e linguagem. A construção da personagem também se liga a esse tema: Meursault não é apenas um homem cuja indiferença se liga ao absurdo, mas um homem cuja sensibilidade se liga às núpcias e à sua relação com a natureza.

A natureza também representa o avesso e o direito na narrativa, ela é tanto signo de uma positividade quanto de uma negatividade, e essa ambivalência pode ser observada desde os 
primeiros escritos de Camus. O sol é principalmente o tema no qual essa ambivalência se destaca: o calor e a luminosidade estão ligados as núpcias com a natureza e quando se contrapõe à morte é que esse tema se torna trágico, como nas passagens do enterro, do assassinato e da condenação.

Dessa forma, essa estrutura profunda que organiza o texto, sustentada a partir do avesso e o direito, tem relação com o percurso filosófico de Camus e resulta em uma poética, segundo a qual só é possível escrever entre as núpcias e o absurdo, entre a filosofia e a literatura. Assim como Meursault, que no final de sua história se abria para a terna indiferença do mundo, concluímos que L'Étranger é uma narrativa ternamente indiferente, o que justifica a inquietação apaixonada que ela nos desperta.

Quinze anos depois da publicação de "Noces à Tipasa", após vários anos vivendo na Europa experimentando o absurdo da guerra e do exílio, Camus retorna a Tipasa de sua nostalgia, lugar emblemático das núpcias com o mundo, e escreve:

J'ai quitté de nouveau Tipasa, j'ai retrouvé l'Europe et ses luttes. Mais le souvenir de cette journée me soutient encore et m'aide à accueillir du même cœur ce qui transporte et ce qui accable. À l'heure difficile où nous sommes, que puis-je désirer d'autre que de ne rien exclure et d'apprendre à tresser de fil blanc et de fil noir une même corde tendue à se rompre ? Dans tout ce que j'ai fait ou dit jusqu'à présent, il me semble bien reconnaître ces deux forces, même lorsqu'elles se contrarient. (L'été, 2008, p. 165) ${ }^{233}$

Até este momento, esse é exatamente o aprendizado do escritor: saber tecer de fio branco e fio negro os seus textos, essa corda da escritura prestes a se romper onde se entrelaçam núpcias e absurdo, absurdo e revolta, revolta e amor.

233 "Uma vez mais, tornei a sair de Tipasa para ir ao encontro da Europa e de suas lutas. Mas a recordação daquele dia ainda me serve de alento, ajudando-me a aceitar com idêntico ânimo as coisas que nos arrebatam e as que nos abatem. No momento difícil em que estamos, que outra coisa posso desejar senão que nada seja excluído e que aprendamos a trançar o fio branco junto ao fio negro numa mesma corda retesada, prestes a romper-se? Em tudo aquilo que fiz ou disse até agora, parece-me reconhecer bastante bem essas duas forças, mesmo quando se contrariam." (O verão, 1979, p. 128) 


\section{Aberturas críticas}

Essa pequena análise em perspectiva dos escritos camusianos entre os anos de 1932 e 1942 permite-nos levantar a hipótese de que esse processo repetiu-se nos anos que se seguiram.

O percurso filosófico, iniciado com o tema das núpcias, conduziu ao absurdo, que por sua vez conduziu à revolta, mas essa passagem não significa, porém, o abandono total do tema anterior. A revolta, por sua vez, conduziu a outro tema, o amor, para o qual Camus previra um novo ciclo de obras. Ele escreve nos Carnets em 1946: “Assim, partindo do absurdo, não é possível viver a revolta sem culminar em algum ponto que seja uma experiência do amor que ainda está por definir." (tradução nossa). ${ }^{234}$ Esse projeto de falar do amor aparece em diversas notas dos Carnets, ${ }^{235}$ entre elas encontramos uma longa reflexão aproximando a revolta do amor: "Ensaio sobre a Revolta. Depois de ter retirado a filosofia da angústia: retirá-la da alegria. Id. Regenerar o amor em um mundo absurdo é na verdade regenerar o mais ardente e o mais perecível dos sentimentos humanos." (tradução nossa). ${ }^{236}$ Nesta nota, Camus ressalta que o amor é sobretudo um sentimento humano, por isso sua reflexão sobre o amor não se liga de modo algum ao cristianismo ou à experiência religiosa. Porém, diferentemente das noções de absurdo e revolta, não há um texto de reflexão filosófica sobre o amor; se queremos buscá-lo dentro dos

\footnotetext{
${ }^{234}$ Ainsi, parti de l'absurde, il n'est pas possible de vivre la révolte sans aboutir en quelque point que ce soit une expérience de l'amour qui reste à définir.” (C II, 1965, p. 177)

${ }^{235}$ “Si l'œuvre, produit de la révolte, résume l'ensemble des aspirations de l'homme, elle est forcement idéaliste (?). Ainsi le plus pur produit de la création révoltée, c'est le roman d'amour qui..."(C II, 1965, p. 117)

"Roman du suicidé à terme. Fixé à un an - sa formidable supériorité du fait que la mort lui est indifférente.

Le lier à roman sur amour ?" (C II, 1965, p. 124)

"Révolte : Créer pour rejoindre les hommes ? Mais peu à peu la création nous sépare de tous et nous rejette au loin sans l'ombre d'un amour." (C II, 1965, p. 143)

${ }^{236}$ Essai sur la Révolte. Après avoir fait partir de l'angoisse la philosophie : la faire sortir du bonheur.Id. Régénérer l'amour dans le monde absurde, c'est en fait régénérer le plus brûlant et le plus périssable des sentiments humains (Platon : «Si nous étions des dieux, nous ne connaitrions pas l'amour »). Mais il n'y a pas de jugement de valeur à porter sur l'amour durable (sur cette terre) et celui qui ne l'est pas. Un amour fidèle - s'il ne s'appauvrit pas - est une manière pour l'homme de maintenir le plus possible le meilleur de lui-même. C'est par là que se trouve revalorisée la fidélité. Mais cet amour est en dehors de l'éternel. C'est le plus humain des sentiments avec ce que le mot comprend à la fois de limitation et d'exaltation. C'est pour cela que l'homme ne se réalise que dans l'amour parce qu'il y trouve sous une forme fulgurante l'image de sa condition sans avenir (et non comme disent les idéalistes parce qu'il approche une certaine forme de l'éternel). Le type : Heathcliff. Tout ceci illustration du fait que l'absurdité a sa formule dans l'opposition entre ce qui dure et ce qui ne dure pas. Étant entendu qu'il n'y a qu'une façon de durer qui est de durer éternellement et qu'il n'y a pas de milieu. Nous sommes du monde qui ne dure pas. Et tout ce qui ne dure pas - et rien que ce qui ne dure pas - est nôtre. Il s'agit ainsi de reprendre l'amour à l'éternité ou du moins à ceux qui le travestissent en image d'éternité. Je vois d'ici l'objection : c'est que vous n'avez jamais aimé. Laissons cela. (C II, 1965 , p. 75)
} 
escritos camusianos devemos retornar aos primeiros escritos e o encontraremos principalmente no amor maternal e no amor pela terra argelina.

No prefácio à L'Envers et L'Endroit, publicado em 1958, o escritor expressa o desejo de reescrever o ensaio e de colocar ainda no centro de sua obra o admirável silêncio de uma mãe e o esforço de um homem para reencontrar uma justiça ou um amor que equilibre esse silêncio (EE, 2007, p. 31). Nesse mesmo prefácio, Camus identifica L'Envers et L'Endroit como a fonte de tudo que escreveu: como já vimos, se encontram lá a maioria dos temas que Camus explorará em textos posteriores. Mas essa fonte está ainda mais profundamente no mundo de pobreza e luz onde ele viveu por muito tempo (EE, 2007, p. 13). O equilíbrio entre a miséria e o sol em sua infância o privou de todo o ressentimento; na África o mar e o sol são como uma graça. Anos mais tarde, ao descobrir os bairros operários da Europa, ele compreendeu que mesmo a mais extrema miséria árabe não pode se comparar a essa diferença de céus. Essa feliz imunidade ao ressentimento e à amargura da pobreza ele também deve aos seus, a quem faltava quase tudo e invejavam pouco mais do que nada. Essa família que não sabia sequer ler ofereceu a ele apenas por seu silêncio as suas mais profundas lições (EE, 2007, p. 15). Surgem assim outros temas caros à escritura camusiana: a Argélia, a pobreza, a família, enfim, a infância. A infância é uma espécie de paraíso perdido que ele deseja reencontrar pela mediação da memória.

Todos esses temas estarão presentes de uma maneira ou outra nos ensaios de L'Envers et L'Endroit e mais especialmente na terceira história de "L'Ironie" e em "Entre oui et non". E nascem muito possivelmente de uma experiência pessoal, como nos autoriza pensar o prefácio.

Esses temas, por sua vez, já haviam aparecido nos escritos de juventude: "Le Courage" é a primeira versão do que viria a ser a terceira história de "L’Ironie", assim como a primeira história de "Les Voix du quartier pauvre" é a primeira versão de "Entre oui et non". Como vimos, essas histórias serão entrelaçadas sob um personagem, "Louis Raingeard", na primeira tentativa de romance que Camus empreende. Encontramos, assim, na relação entre esses primeiros escritos outro procedimento da escritura camusiana: sua relação com a experiência pessoal do escritor.

A escrita de La Mort Heureuse também guarda muito dessas reminiscências pessoais: a narrativa explora as lembranças do bairro pobre onde Camus passou a infância, Belcourt, de seu emprego como despachante marítimo, de sua viagem à Europa Central no verão de 1936 e de suas passagens pela Itália em 1936 e 1937, que também são retomadas nos ensaios de Noces. 
Em L’Étranger, essas histórias da infância parecem se dissipar e a relação com a experiência pessoal se enfraquece (embora possa ser encontrada através de alguns traços: por exemplo, Meursault mora no mesmo endereço onde Camus cresceu). Como vimos, a narrativa é compreendida como um mito, isto é, o ponto de encontro entre a literatura e a filosofia. Ela é portanto simbólica:

Mon oeuvre pendant ces deux premiers cycles: des êtres sans mensonges, donc non réels. Ils ne sont pas au monde. C'est pourquoi sans doute jusqu'ici je ne suis pas un romancier au sens ou l'entend. Mais plutôt un artiste qui crée des mythes à la mesure de sa passion et son angoisse. (C III, p. 1090-1091) $)^{237}$

Essas narrativas ligadas ao mito, como é também La Peste, não são concebidas por Camus como romances. Retomando o prefácio de 1958, ao retraçar o caminho de sua escritura, ele escreve que se apesar de tantos esforços para edificar uma linguagem e fazer viver mitos ele não conseguir reescrever L'Envers et L'Endroit, ele não terá conseguido nada (EE, 2007, p. 31).

Reescrever os ensaios é, dessa forma, se distanciar do mito, dessa escrita que oscila entre literatura e filosofia ${ }^{238}$ e retornar a uma escrita que nasce simplesmente de sua vida: "Desde os meus primeiros livros [...], todo o meu esforço foi na realidade em me despersonalizar (cada vez em um tom diferente. Em seguida, eu poderia falar em meu nome." (tradução nossa). ${ }^{239}$

No prefácio, Camus expressa o desejo de estabelecer o equilíbrio entre o que ele é e o que ele diz; é só assim que ele poderá empreender a obra com a qual sonha: uma obra que se parecerá com L'Envers et L'Endroit e que falará de uma certa forma de amor (EE, 2007, p. 29). O tema do amor liga-se assim a um novo procedimento de escritura.

\footnotetext{
237 "Minha obra durante esses dois primeiros ciclos: seres sem mentiras, logo não reais. Eles não estão no mundo. É por isso que eu duvido que até aqui eu não seja um romancista no sentido do termo. Mas sobretudo um artista que cria mitos na medida de sua paixão e de sua angústia." (tradução nossa)

${ }^{238}$ Essa relação é dissimulada, uma vez que o absurdo nasce de uma experiência pessoal: há um documento, geralmente chamado de "Cahier resté à Oran", que mostra como a reflexão de Camus sobre o absurdo procede dessa experiência, principalmente a da doença. A redação é feita em primeira pessoa e o texto é totalmente retomando em Le Mythe de Sysiphe, substituindo o "je" por "l'homme quotidien", "l'homme absurde": "Ce qui compte c'est que dans la nuit qui suivit je ne dormis pas et me promenais de long em large. Peu importe si je suis encore capable de cette extrémité dans la douleur. Ce qui compte ce que pendant trois jours je ne sortis pas de chez moi et je restais des heures à contempler mes mains ou à courir chercher dans une glace cet être étrange et glacé qui venait de naître. Je ne dirais pas que tout est sorti de ces trois jours - Mais l'essentiel. Jusqu'ici j'avais vécu avec des buts, avec un souci d'avenir et de justification qui dirigeait ma vie. [...] Cette nuit-là tout s'écroula." Cf. "Sans lendemains" (OC I, 2010, p. 1198-1204).

239 "Depuis mes premiers livres [...], tout mon effort a été en réalité de me dépersonnaliser (chaque fois dans un ton différent). Ensuite, je pourrais parler en mon nom.” (C III, 1989, p. 1002)
} 
$\mathrm{O}$ ano em que Camus escreve esse prefácio é exatamente o ano no qual, depois de 20 anos, Camus arrisca essa reescritura ao se dedicar ao romance Le Premier Homme, no qual se entrelaçam a ficção e a autobiografia. Esse texto liga-se com todo o resto da obra de Camus, principalmente ao retomar os temas caros ao pensamento camusiano: o amor pela mãe e o amor pela terra onde nasceu. De um extremo ao outro da obra, os ensaios e os escritos de juventude são o ponto fundamental para compreender a escritura camusiana. 


\section{REFERÊNCIAS}

AMIOT, Anne-Marie ; MATTÈI, Jean François (Org.). Albert Camus et la philosophie. Paris: Presses Universitaires de France, 1997.

ARAGON, Louis. D'un grand art nouveau: la recherche. In: Essais de critique génétique. Paris: Flammarion, 1979.

BERGEZ, Daniel. A crítica temática. In: Métodos críticos para a análise literária (Trad. de Olinda Maria R. Prata). São Paulo: Martins Fontes, 1997.

BARTHES, Roland. Réflexion sur le style de «L'Étranger». In: CEuvres Complètes. Paris: Ed. du Seuil, 1995.

. Le degré zéro de l'écriture. Paris: Ed. du Seuil, [1953]1972.

2004. . Inéditos, vol. 2: crítica (Trad. de Ivone Castilho Benedetti). São Paulo: Martins Fontes, . Leçon. Paris: Ed. du Seuil, [1978] 1989.

. O prazer do texto (Trad. de J. Guinsburg). São Paulo: Perspectiva, 2010.

BONNICI, Thomas; ZOLIN, Lúcia Osana (Org.). Teoria Literária: abordagens históricas e tendências contemporâneas. Maringá: Eduem, 2009.

BORNHEIM, Gerd A. O Sentido e a Máscara. São Paulo: Perspectiva, 1992.

CAMUS, Albert. A inteligência e o cadafalso e outros ensaios (Trad. de Manuel da Costa Pinto e Cristina Murachco). Rio de Janeiro: Record, 2008.

. Carnets I: 1935-1942. Paris: Gallimard, 1962.

. Carnets II: 1942-1951. Paris: Gallimard, 1965.

. Essais. Paris: NRF/Gallimard/Bibliothèque de la Pléiade, 1981.

. L'envers et l'endroit. Paris: Gallimard, [1958] 2007. (Collection Folio Essais).

. L'étranger. Paris: Gallimard, [1942] 1996. (Collection Folio).

. L'homme révolté. Paris: Gallimard, 1951. (Collection NRF).

. La mort heureuse. In: Cahiers Albert Camus I. Paris: Gallimard, 1971.

. Le mythe de Sisyphe : essai sur l'absurde. Paris: Gallimard, [1942] 2008. (Collection

Folio Essais). 
. Le Premier Homme. Paris: Gallimard, 2008. (Collection Folio).

. Noces suivi de L'été. Paris: Gallimard, [1938] 2008. (Collection Folio).

. Núpcias, o Verão (Trad. de Vera Queiroz da Costa e Silva). Rio de Janeiro: Nova Fronteira, 1979.

. O estrangeiro (Trad. de Antonio Quadros). São Paulo: Abril, 1979.

. O homem revoltado (Trad. de Valérie Rumjanek). Rio de Janeiro: Record, 1996.

. O mito de Sísifo (Trad. de Ari Roitman e Paulina Watch). São Paulo: Record, 2008.

. Oeuvres Complètes. Paris: Gallimard/Bibliothèque de la Pléiade, 2010. t. I.

. Réflexions sur la guillotine. In: KOESTLER, Arthur; BLOCH-MICHEL, Jean. Réflexions sur la Peine Capital. Paris : Calmann-Lévy, 1957.

. Théâtre, Récits, Nouvelles. Paris: NRF/Gallimard/Bibliothèque de la Pléiade, 1981.

CAMPION, Pierre. Pour une approche philosophique de la littérature. In: La Littérature à la recherche de la Vérité. Paris: Éditions du Seuil, 1996.

CANDIDO, Antônio et al. A personagem da ficção. São Paulo: Perspectiva, 2009.

CASTEX, Pierre-Georges. Albert Camus et l'Étranger. Paris: Librarie José Corti, 1965.

COMPAGNON, Antoine. $O$ demônio da teoria: literatura e senso comum (Trad. de Cleonice Paes Barreto Mourão e Consuelo Fortes Santiago). Belo Horizonte: Ed. UFMG, 2003.

CORBIC, Arnaud. Camus: l'absurde, la révolte, l'amour. Paris: L'Atelier, 2003.

GASSIN, Jean. L'univers symbolique d'Albert Camus: essai d'interprétation psychanalytique. Imprenta [Paris]: Minard, 1981.

GENGEMBRE, Gérard. Les grands courants de la critique littéraire. Paris: Seuil, 1996.

GENETTE, Gérard. Nouveau discours du récit. Paris: Le Seuil, 1983.

GUÉRIN, Jeanyves (Org.). Dictionnaire Albert Camus. Paris: Robert Laffont, 2009. (Coleção Bouquins).

GRENIER, Roger. Albert Camus, soleil et ombre: une biographie intellectuelle. Paris: Gallimard, 1999. abr. 1990.

Les Carnets: des notes de travail au journal intime. Magazine Littéraire, n. 276, p. 18-53,

GRÉSILLON, Almuth. Éléments de critique génétique Lire les manuscrits modernes. Paris: PUF, 1994.

Proust ou l'écriture vagabonde. In: Marcel Proust: écrire sans fin Paris: CNRS, 1996. 
HAAG, Carlos. À sombra dos manuscritos em flor. Revista Pesquisa Fapesp, n. 155, p. 98-101, jan. 2009.

HAY, Louis et al. Carnets d'écrivains 1 : Hugo, Flaubert, Proust, Valéry, Gide, du Bouchet, Perec. Paris, CNRS, 1990. (Textes et manuscrits).

2007.

A literatura dos escritores: questões de crítica genética. BeloHorizonte: Ed. UFMG,

HULLE, Dirk Van. Économie textuelle: recyclage chez Proust, Mann et Joyce. Genesis, n. 18, p. 91-103, Éditions Jean-Michel Place, 2002.

LAMEIRINHA, Cristianne A. de B. O sentido do exílio em La Peste de Albert Camus. Dissertação de Mestrado. Universidade de São Paulo, São Paulo, 2006.

LÉVI-VALENSI. Albert Camus ou la naissance d'un romancier. Paris: Gallimard, 2006.

; GAY-CROSIER, R. Albert Camus: oeuvre fermée, oeuvre ouverte?. In: Cahiers Albert

Camus V. Paris: Gallimard, 1982.

Les critiques de notre temps et Camus. Paris: Garnier, 1970.

MALHADAS, Daisi. Tragédia Grega: o mito em cena. Cotia: Ateliê Editorial, 2003.

MÉLANÇON, Marcel. Albert Camus : analyse de sa pensée. Suisse: Les Éditions Universitaire Fribourg, 1976.

PINGAUD, Bernard. L'Étranger. Paris: Gallimard, 1992.

PINO, Claudia; ZULAR, Roberto. Escrever sobre escrever: uma introdução crítica à crítica genética. São Paulo: Wmf Martins Fontes, 2007.

PINTO, Manuel da Costa. Albert Camus: um elogio do ensaio. São Paulo: Ateliê Editorial, 1998.

POULET, Georges. La conscience critique. Paris: José Corti, 1986.

PROUST, Marcel. Le Temps Retrouvé. Paris: Gallimard, 1989.

QUILLIOT, Roger. La mer et les prisons : essais sur Albert Camus. Viena: Gallimard, 1970.

REY, Pierre-Louis. L'étranger Camus. Paris: Hatier, 1970.

ROSENFELD, Anatol. Reflexões sobre o romance moderno. In: Texto/ Contexto II : Ensaios. São Paulo: Perspectiva, 1993.

SABOT, Philippe. Philosophie et littérature : approches et enjeux d'une question. Paris: Presses Universitaires de France, 2002.

SALLES, Cecília Almeida. Gesto inacabado: processo de criação artística. São Paulo: FAPESP/Annablume, 2009. 
SAPATERRO, Fernando Rocha. Albert Camus: a felicidade e a relação homem-natureza em diálogo com Epicuro. Dissertação de Mestrado. Pontifícia Universidade Católica, São Paulo, 2005.

SARTRE, Jean-Paul. Explicação de O Estrangeiro. In: Situações I: crítica literária. São Paulo: Cosac Naify, 2005.

SILVA, Franklin Leopoldo e. Ética e literatura em Sartre: ensaios introdutórios. São Paulo: Ed. Unesp, 2004.

. Romance e filosofia no existencialismo de Sartre. Imprenta São Paulo: Abralic: Aderaldo; Rothschild, 2008. p. 75-84.

SILVA, Nilson Adauto Guimarães da. Platão e Camus: As "origens" da literatura e da filosofia. In: IV CONGRESSO NACIONAL DE ESTUDOS CLÁSSICOS/XII REUNIÃO DA SBEC, 2001, Ouro Preto. In: Antiguidades. Ouro Preto, MG: Ufop, 2001. v. único. p. 63.

. Albert Camus e a busca dos clássicos. Calíope,n. 17, p. 74-94, 2007.

. A revolta na obra de Albert Camus: posicionamento no campo literário, gênero, estética e ética. Tese de Doutorado. Universidade Federal do Rio de Janeiro, Rio de Janeiro, 2008.

SOUZA, Thana Mara de. Sartre e a literatura engajada: espelho crítico e consciência infeliz. São Paulo: Edusp, 2008.

STAROBINSKI, Jean de. L'oeil vivant 2, La relation critique. Paris: Gallimard, 1989.

. Jean-Jacques Rousseau: la transparence et l'obstacle. Paris: Gallimard, 1991.

TODD, Olivier. Albert Camus : une vie. Paris: Gallimard, 1999.

VIALLANEIX, Paul. Le premier Camus Suivi de Écrits de Jeunesse d'Albert Camus. In: Cahiers Albert Camus II. Paris: Gallimard, 1973.

VIRCONDELET, Alain. Albert Camus : fils d'Alger. Paris: Fayard, 2006.

WILLEMART, Philippe. A crítica genética diante do programa de reconhecimento vocal. Manuscrítica, n. 12, 2004.

. Crítica genética e psicanálise. São Paulo: Perspectiva; Brasília, DF: Capes, 2005.

2009. . Os processos de criação na escritura, na arte e na psicanálise. São Paulo: Perspectiva,

ZULAR, Roberto (Org.). Criação em Processo: ensaios de crítica genética. São Paulo: Iluminuras, 2002. 